\title{
A Critical Approach to the Efficacy of the Economic Development Strategy in Interethnic Conflict Prevention and Resolution
}

\author{
by
}

Limingcui Emma Huang

A thesis submitted to the Faculty of Graduate and Postdoctoral Affairs in partial fulfilment of the requirement for the degree of

Master of Arts in Political Economy

Institute of Political Economy

Carleton University

Ottawa, Ontario, Canada

(C2018, Limingcui Emma Huang 


\section{Table of Contents}

TABLE OF CONTENTS

INDEX OF FIGURES AND TABLES

IV

LIST OF ACRONYMS

V

$\begin{array}{ll}\text { ABSTRACT } & \text { VI }\end{array}$

ACKNOWLEDGEMENTS

VII

PART I RESEARCH FOUNDATIONS

$-1-$

1 INTRODUCTION

1.1 OVERVIEW OF THE STUDY

-1 -

$-1-$

1.2 StRUCTURE AND METHODS OF ARGUMENTS

$-5-$

1.3 KEY TERMS AND RESEARCH PARAMETER

$-7-$

1.4 SigNIFICANCE OF THE STUDY

$-9-$

2 BACKGROUND: THE UYGHUR-HAN RELATIONSHIP

2.1 XINIIANG'S GEOPOLITICAL IMPORTANCE

-11 -

2.2 XINIIANG'S CHALLENGES FOR CHINA

$-11-$

2.3 THE STATE'S RESPONSES AND RESUlTS

$-18-$

$-21-$

3 PUZZLE: INTERETHNIC VIOLENCE ON THE RISE

$-28-$

3.1 TABULATION OF THE UYGHUR-HAN CONFLICTS

$-28-$

3.2 CONFLICT PATTERNS AND MOTIVATION OF RESEARCH

$-31-$

4 Theoretical Framework: THE "SONS OF THE SOIL" CONFLICTS, FeMinist POLITICAL ECONOMY, AND INTERETHNIC POLICY ANALYSES

4.1 “SONS OF THE SOIL" (SOS) CONFLICTS

$-35-$

$-35-$

4.1.1 Defining SoS

$-35-$

4.1.2 Understanding the Significance of SoS

$-37-$

4.1.3 Differentiating SoS, Ethnic Conflicts, and Civil Wars

$-41-$

4.2 A FEMINIST POlitical ECONOMY (FPE) APPROACH TO CONFLICTS

-47 -

4.2.1 The Influences of Gender Stereotypes on Conflict Organization - 47 -

4.2.2 Exploitation of Women during Conflicts - 49 -

4.2.3 Gender Stereotypes and Exploitation in The SoS Conflicts $\quad 51$ -

PART II CASE STUDIES

$-57-$

5 THE UYGHUR-HAN CONFLICTS: CLASSIC SOS CASES

$-57-$

5.1 APPLYING SOS TO THE UYGHUR-HAN CONFLICTS

$-57-$

5.2 APPLYING FPE IN THE UYGHUR-HAN CONFLICTS

$-60-$

6 QUALITATIVE ANALYSIS: EDS, GENDERED POLICY OUTCOMES, AND CONFLICTS

6.1 LOGIC AND PROBLEMS OF THE EDS

$-63-$

6.2 A SuRvey OF EDS-RELATEd POlicies AND CONSEQUENCES IN THE XUAR

$-63-$

$-67-$ 
6.2.1 The Xinjiang Production and Construction Corps - 67 -

6.2.2 The Great Western Region Development

6.2.3 The Labour Export Program $\quad$ - 75 -

6.2.4 The Rapid Spike Projects

6.3 LiNKING GENDERED POLICY OUTCOMES, HIS, AND CONFLICTS

7 EMPIRICAL ANALYSIS: GENDERED OUTCOMES OF THE EDS AND THE UYGHUR-HAN CONFLICTS

7.1 RESEARCH DESIGN

$-85-$

$-85-$

7.1.1 Stages of Testing and Rationale $\quad-85$ -

7.1.2 Variables and Data Collection - 87 -

7.2 RESULTS AND DISCUSSION

7.2.1 The Uyghur-Han Conflicts and SoS Patterns - 92 -

7.2.2 Influence of the EDS on The Uyghur-Han Conflicts - 95 -

7.2.3 Verifying Quantitative Findings - 100 -

7.2.4 Accounting for the Discrepancies with FPE - 106 -

8 CONCLUSION: A CRITICAL APPROACH TO INTERETHNIC CONFLICTS - 109 -

8.1 REVISITING STUDY FINDINGS IN THE UYGHUR-HAN CONFLICTS - 109 -

8.2 CONTEMPLATING FUtURE RESEARCH - 114 -

$-117-$ 


\section{Index of Figures and Tables}

Figure 1 Location of the XUAR and Its Capital Urumqi in China and Eurasia - 13 Figure 2 Ocean and Land Oil and Gas Transportation Routes - 16 -

Figure 3 Average Annual Income Discrepancy, Public and Private Industries in Xinjiang, $2015 \quad-24$ -

Figure 4 Uyghur-Han Violent Incidents within China, 1980-Present, by Year $\quad 31$ -

Figure 5 Uyghur-Han Violent Incidents within China, 1980-Present, by Location - 33 Figure 6 Population Construction Changes in the XUAR, 2001-2016 - 99 -

Figure 7 Residuals-Fitted Values Plot 107 -

Table 1 Average Annual Income across Industries in Xinjiang, 2015, Details $\quad 26$ Table 2 Uyghur-Han Violent Incidents within China, 1980-Present, Chronicled $\quad 29$ Table 3 Benchmark Values for Empirical Analysis $\quad$ - 87 Table 4 Summary of Variables $\quad 91$ Table 5 Conflict Frequency and Uyghur/Han Population Ratio, 2001-2016 - 93 Table 6 Conflict Frequency and Ethnic Attachment to Land, 2001-2016 - 94 Table 7 Conflict Frequency and Ethnic Attachment to Land, 2007-2016 - 97 Table 8 Conflict Frequency and Uyghur/Han Population Ratio, 2001-2016, with GDP Per Capita Added 101 -

Table 9 Conflict Frequency and Ethnic Attachment to Land, 2001-2016, GDP Per Capita Added - 102 -

Table 10 Conflict Frequency and Ethnic Attachment to Land, 2007-2016, GDP Per Capita Added

Table 11 Conflict Frequency and Gendered Migration and Employment, 2007-2017, GDP Per Capita Added $-105-$ 


\section{List of Acronyms}

$\begin{array}{ll}\text { COW } & \text { Correlates of War } \\ \text { CPC } & \text { Chinese Communist Party } \\ \text { RSP } & \text { Rapid Strike Program } \\ \text { EDS } & \text { Economic Development Strategy } \\ \text { FPE } & \text { Feminist Political Economy } \\ \text { HI } & \text { Horizontal Inequality } \\ \text { LEP } & \text { Labour Export Program } \\ \text { PLA } & \text { People's Liberation Army } \\ \text { PRC } & \text { People's Republic of China } \\ \text { PRIO } & \text { Peace Research Institute Oslo } \\ \text { SIPRI } & \text { Stockholm International Peace Research Institute } \\ \text { SoS } & \text { Sons of the Soil } \\ \text { GWRD } & \text { Great Western Region Development } \\ \text { XPCC } & \text { Xinjiang Production and Construction Corps } \\ \text { XUAR } & \text { Xinjiang Uyghur Autonomous Region }\end{array}$




\begin{abstract}
Since the late 1980s, China has adopted an economic development strategy (EDS) to invest in the Uyghur economic well-being in exchange for obedience. Despite this, the conflicts have become more frequent. Under the framework of "Sons of the Soil" conflicts and Feminist Political Economy, one finds a causal relation between gendered employment and migratory patterns resulting from the EDS, and the escalation of Uyghur-Han conflicts. Between the late 1980s and mid-2000s, EDS policies attracted male-dominated Han in-migration to Xinjiang. Influenced by gender biases, Xinjiang locals viewed these migrants as threats to their economic and personal security. This aggravates grievances against the Han-dominant ruling. Since the mid-2000s, EDS policies have caused an out-flow of Uyghur women from Xinjiang, leaving Uyghur men behind. This has challenged the patriarchal values and order among the Uyghur and thereby contributed to the conflicts.
\end{abstract}




\section{Acknowledgements}

The nature of studying abroad and producing theses can be intimidating and isolating. Fortunately, I have enjoyed great companies from many sweet and smart individuals throughout my adventures. They help transforming obstacles into opportunities, and therefore enabling me to do better and go further.

I cannot wait until the publication of this acknowledgment to thank my awesome supervisor, Dr. Mira Sucharov from the Department of Political Science at Carleton University. She has consistently demonstrated her wonderful command of professional knowledge and wholehearted care for her students. Thank you, Mira, for your faith in my work ethic and professional training. I get to experiment and challenge myself with novel theories and ideas. In the meantime, you are so generous in sharing your expertise and insights. Your challenging questions propel me to perfect my work in every possible aspect. I am eternally grateful for your empathy and support when I am stuck in difficulties. Without your guidance, I would never be able to complete this work with quality and sanity.

I want to thank Dr. Randall Germain from the Department of Political Science and Dr. José Galdo from the Department of Economics at Carleton University. You made yourselves available even when my thesis was but a rough prototype. You patiently went through my scrambling, distilled my best thoughts, and provided me with theoretical and methodological advices. You equipped me with solid foundations on which I can develop this project meaningfully. I thank Dr. Xiaowei Zang from the City University of 
Hong Kong and Dr. Björn Gustafsson from the University of Gothenburg. You pointed me to a gold mine of research resources essential to this study.

Thank you, dearest Donna Coghill and Dr. Cristina Rojas for bringing me to the Institute of Political Economy and enabling me for all these great learning and working opportunities. You watched out for me, advocated for me, and went beyond and above to ensure my best interests. I will always miss walking into your offices feeling like I am back home.

A special thank-you goes to my alma mater, Memorial University of Newfoundland and the amazing people there. Especially, I want to thank Dr. Isabelle Côté. You took that one small question I posed in class three years ago, guided me to develop it into a sound academic work, and even let me present it on our behalf on a national conference! Your mentorship is a key reason why I have the gut to challenge myself to delve into this new realm of studies I was not familiar with before.

谢谢爸爸妈妈的养育、鼓励、栽培。谢谢爸爸以身作则教我上进求知。你的博闻强 识无时不刻鞭策我广泛而深入地挖掘新旧知识领域。谢谢妈妈坚定不移的支持和陪伴。你 为我爱心和细心地周全几乎一切, 让我能依从内心追随兴趣爱好多方位发展。谢谢你们让 我看见和体验世界的辽阔深奥美丽，也因而让我更珍惜小小家庭的简单平凡温暖。谢谢 Kenzie，一路与我分担寒潮、风雷、霹雾，和我共享雾露、流岗、虹䨳。Un gros merci à Geneviève, Alexandre, Carol et Stéphane. Pour moi, vous êtes ma famille ici en Canada. Je vous remercie d'avoir pris bon soin de moi. I also thank my cohort at the Institute of Political Economy for making difficult days still full of hope and laughter. 
Many people have kindly invested their precious time and effort to help ensure the quality of this work. I thank the members of my star defence committee, Dr. Jeremy Paltiel from the Department of Political Science and Dr. Yanling Wang from Norman Paterson School of International Affairs at Carleton University. It is a great privilege to learn from the subject matter experts whose work I have spent days and nights exploring. Thank you, Kenzie, Jason, Mike, Jack and Peter for pushing yourself through the very long document to ensure its precision. Thank you, Tao, Quan, and Carlie, for being my great cheerleaders along the way.

The data collection would not be as easy without the Graduate Student Travel/Research Bursary, generously funded by the Faculty of Graduate and Postdoctoral Affairs. I thank Donna, Mira, and the Institute of Political Economy for supporting my application for the funding.

Finally, Dr. Chris Dunn, I hope you would be proud to see what I have accomplished with all the knowledge, skills, and opportunities you had so kindly and generously bestowed on me. 


\section{Part I Research Foundations}

\section{Introduction}

\subsection{Overview of the Study}

For decades, recurring open clashes have impeded the peaceful cohabitation between the Han, China's ethnic majority, and the Uyghur, one of its biggest minority groups. To curb these public violent incidents and to reinstate regional stability, China has adopted an economic development strategy (EDS) since the end of 1980s. The EDS entails policies that invest in the economic well-being of the Uyghur and their autonomous region, Xinjiang. Underpinning this strategy is the belief that economic prosperity will "buy" Xinjiang locals' obedience and loyalty to the state governance (Clarke, 2015, pp. 128-129). The Chinese central government believes that, as a result of the EDS Xinjiang will be more stable and prosperous than its bordering countries with similar ethnic and linguistic characteristics, and such comparisons should bolster the obedience and loyalty as well (Dorian, et al., 1997, p. 465).

Opposite to the expectations, the EDS-relevant policies have not successfully reduced the interethnic conflicts to a satisfactory level. Even worse, the frequency and severity of interethnic violence have been escalating in the past decade, filling citizens' everyday lives with uncertainty and horror. Why has China's economic development strategy not been effective in safeguarding interethnic peace in Xinjiang? Under this haunting spectre of violence, resolving this puzzle has become more significant than ever.

More often than not, ethnicity is cited to account for these conflicts. Although an explanation, ethnicity is not the ultimate, irreducible explanatory factor of these clashes 
(Wolff, 2006). What constitutes an ethnic identity? The answer varies, because ethnicity can have a fluid or static definition. Accordingly, self-identification, group inclusion, and otherness can be created based on tangible or intangible, so-called ethnic characteristics (Cordell \& Wolff, 2009; Wolff, 2006; Lake \& Rothchild, 1998). Still, conflict organizations invoke the notion of ethnicity - however defined - as an effective means to mobilize and to contest for authority and resources. Therefore, the core of the Uyghur-Han conflicts and cases alike is not ethnicity per se, but instead the contestations over power and interests constructed as ethnic issues. Indeed, although ethnicity plays a role, the inter-group disputes over natural resources, social status, economic opportunities, and political power are at the heart of the Uyghur-Han conflicts. Since the traditional ethnic conflict approach masks underlying political, socio-economic and cultural issues, this study moves beyond the apparent ethnic component and explores factors closer to the root causes to help provide greater understanding of the Uyghur-Han conflicts and the inefficacy of the EDS in Xinjiang

In consideration of the complexity of the issue, this study draws lessons from the "Sons of the Soil (SoS)" conflicts literature (Weiner ,1978) to help with the analyses of the Uyghur-Han conflicts. A growing niche in conflict studies, SoS is a concept that allows one to explore the mutual, reciprocal influences of ethnic identities and the contestations of authority and resources. It enables one to integrate theories from ethnic studies, conflict studies, and political economy, and thus allows a holistic and more precise grasp of the issues. The concept of the SoS conflicts is widely applicable to cases around the globe and offers depth and breadth for analyese. This concept is helpful in understanding 
interethnic conflicts in a way of which traditional ethnic conflict theories and civil war theories are incapable.

Meanwhile, the preliminary research shows that the economic development strategy demonstrates gender-patterned policy outcomes in China's internal migration and employment. Such findings enlighten this study to take a critical approach to examine the link between the gendered policy outcomes and the inefficacy of China's EDS in Xinjiang. Hence, this study incorporates a feminist political economy (FPE) approach into the analyses of the Uyghur-Han conflicts, examining how gender layered on top of ethnicity - affects the distribution of power and wealth.

In this case, my inquiry of the effectiveness of China's economic development strategy (EDS) and its relevant interethnic polices unfolds into three more detailed research questions:

1) Do the policies under the EDS result in gender-patterned policy outcomes, and if so, how?

2) Do the gender-patterned policy outcomes render China's economic development strategy ineffective, and if so, how?

3) If the gendered policy outcomes benefit women but contribute to the conflicts, how should the situation be addressed without off-setting women's policy interests?

This study expects to find a correlation among the economic development strategy, the gendered migratory and employment patterns, and the onset frequency of the conflicts. Focusing on the period from the late 1980s to 2016, this study argues that 
China's economic development strategy and relevant interethnic policies have resulted in gendered migratory and employment patterns in the Xinjiang Uyghur Autonomous Region (XUAR) and the overall Uyghur population. Subsequently, this disruption of the gender balance in local demographics and employment graphs on to the interethnic inequalities and aggravates to motivation of conflicts. In detail, this study identifies three such gendered patterns:

1) the masculinization of the in-coming migratory flow of the XUAR - in other words, the migrants coming from other parts of China to the XUAR - prior to and including the 2000s;

2) the feminization of the out-going migratory flow of the XUAR starting towards the end of the 2000s; and

3) the more advantageous employment opportunities that Uyghur women enjoy, in comparison to the Uyghur men, consequent to the EDS implemented starting towards the end of the 2000s. 


\subsection{Structure and Methods of Arguments}

Following such logic, this essay will develop as such: Chapter 2 reviews the historical, cultural, and geopolitical factors that set the background of the Uyghur-Han conflicts. Then, Chapter 3 presents the Uyghur-Han conflicts onset data that the author has tabulated for the incidents occurred in the past decade. This chapter discusses how the empirical evidence demonstrates the inefficacy of China's EDS in the Uyghur-Han conflicts, hence establishing the context for the research puzzle. Chapter 4 provides the theoretical framework of this study. This chapter reviews the existing literature on SoS conflicts and feminist political economy (FPE). In addition, this chapter thoroughly discusses how the concept of SoS conflicts differentiates from traditional ethnic and conflict studies, and is thus beneficial for the study of the Uyghur-Han conflicts and cases alike. Equally important is how a gendered perspective helps with the analysis of the conflict mechanisms. Chapter 5 presents the Uyghur-Han conflicts as classic SoS cases, while Chapter 6 surveys China's EDS policies in Xinjiang since the late 1980s. This chapter explores how the policies under the EDS impact men and women differently in terms of population movement and work, and how these policy outcomes exacerbate the cultural, social, economic, and political inequalities between the Uyghur and the Han people, aggravate the Uyghur's grievances, and thus contribute the conflicts. Afterwards, Chapter 7 presents a data analysis that helps argue how gendered migratory and employment patterns, resulting from the EDS-related policies, correlate with UyghurHan conflict outbreaks in Xinjiang. Together, Chapter 6 and 7 present the qualitative and quantitative analyses that complement each other and demonstrate how the gendered 
migratory and employment patterns, consequent to China's EDS-related policies in Xinjiang, contributed to the Uyghur-Han conflicts. Upon concluding the study, Chapter 8 considers the future trends of similar interethnic conflicts and discusses policy alternatives in response to these rising challenges.

This study aims to provide well-rounded proofs of the hypothesized correlation among EDS-relevant policies, gendered policy outcomes in migration and employment, and the Uyghur-Han conflict outbreaks. This study engages with both qualitative and quantitative methods. In terms of qualitative methods, this study conducts a literature review on existing literature on civil war studies, ethnic conflict studies, Feminist Political Economy, SoS conflicts, and research findings specifically on the Uyghur-Han conflicts. This study also benefits from archival research as it accesses and examines original legislative documents, news publications, governmental reports, recorded interviews, census results, and anecdotal records in both English and Chinese. In this way, this study draws from both primary and secondary literature.

Running time-series within-country data analysis helps capture and model the conflict dynamics, and thereby completes the arguments. Quantitative methods also help vividly display the correlation found. For the sake of organization and readers' convenience, the quantitative research design is detailed in Chapter 7 , together with the statistical analysis of the correlation. 


\subsection{Key Terms and Research Parameter}

Before developing the arguments, a clarification of key terms and the research parameter is in need. Despite the author's personal support of non-binary gender categorization, this study adopts the binary definition of gender to align with the policies examined. Data are available only in binary gender forms. However, this by no means downplays the significance of the consideration of a diverse definition of gender and sex. Ample literature has highlighted renewed forms to understand gender and their positive influence on political organization, mobilization, and participation (Bittner \& GoodyearGrant, 2017). Still, a diverse gender perspective can only follow if and after a gender perspective itself has attracted enough attention in interethnic conflict policies. Likewise, although there are debates on the ethnic categorization in China as Chapter 2 details, this study adopts the definition with which the policies engage while noting problematic elements where appropriate.

As Chapter 3 and 7 indicate, this study recognizes and codes a conflict when academia and media verify the incident by cross-reference. A reaction to a previous conflict, unless it occurs on the same day and in the same venue, is coded as a separate conflict onset. While examining gendered policy outcomes and gendered migration and employment patterns, this study refers to the demographics of policy-related population movement and working status. Chapter 7 presents the details of how these terms are on operationalized.

An EDS-related policy is a development policy that makes capital and human resources investments with the goal of promoting stability. Chapter 6 identifies China's 
EDS policies in Xinjiang and discusses them in chronological order. Before turning to the EDS, the Chinese central government made other policy attempts to ensure its control of Xinjiang. Chapter 2 and 6 briefly review these attempts. In short, China's Uyghur policies centred on military control, Han colonization and assimilation, cultural repression, and political co-option from the 1950s till the end of the 1980s. It was at the intersection of the 1980s and the 1990s that the "development for peace" notion started to be the key of China's Uyghur policies. Accordingly, this study runs in the timeframe that covers the late 1980s until the present day. 


\subsection{Significance of The Study}

This study hopes to contribute to current literature on conflict and gender studies in several ways. To begin with, although extant literature has coded and studied the Uyghur-Han conflicts as typical SoS cases (Fearon \& Laitin, 2011; Cote, 2015), there has yet been a longitudinal case study. In addition, within-country empirical analyses that trace the development of similar conflicts are relatively rare: the most recent one is conducted on the Nepali civil war (Do \& Iyer, 2009). On this end, scholars who are interested in SoS conflicts, especially the Uyghur-Han conflicts, can make use of the approach and data presented in this thesis for future research.

An interdisciplinary approach that brings together SoS and Feminist Political Economy (FPE) provides an innovated perspective on conflict studies and emphasizes the significance of intersectionality. Firstly, as Chapter 4 demonstrates, by operational definitions, traditional ethnic conflict and civil war theories do not capture enduring, low-level open violent clashes. Although incompatible with traditional operational definitions, SoS conflicts like those of the Uyghur-Han cases have significant academic and policy impacts that merit attention. Not only do these clashes cause real agony for the people involved and present legitimate threats to state and regional stability, but they also have potentially exploding influences applicable to the globe (Weiner , 1978; Fearon \& Laitin, 2011). This novel angle that some scholars have started to adopt is hence valuable both for peace research and policy development. Secondly, invoking the concept of SoS and a gender approach, this study shows how women in similar conflicts face multi-level oppressions. During the cause of development, they face inequality as part of 
the peripheries. On the ethnic front, they confront unfairness as members of the minority. Under patriarchy, they are exploited as men's subordinates. As oppressions are multifaceted, so are women's reactions. Accordingly, women's influences on inter-group relations and conflict organizations are multidimensional. In this case, studies and policy prescriptions that are premised on an over-simplified conception of women's role in conflicts are insufficient. It is only when one considers how women's cultural, economic, social, and political roles act and interact that we can start to find a truly efficient solution to interethnic peace. 


\section{Background: the Uyghur-Han Relationship}

\subsection{Xinjiang's Geopolitical Importance}

Xinjiang, or officially known as the Xinjiang Uyghur Autonomous Region, is a provincial-level administrative region in northwestern China (Dorian, et al., 1997). Spanning approximately 1.6 million square kilometres, Xinjiang takes up one sixth of the

Chinese territory, and not surprisingly, is the largest out of China's 34 provincial-level administration region. This vast land houses much of China's ethnic minority population. Reportedly, Xinjiang is the residence of 55 ethnic groups. Among them, 13 are shiju minzu （世居民族） ${ }^{1}$ - ethnic groups that have lived in the region for generations, or in other words, are native to the land (Statistics Bureau of Xinjiang Uyghur Autonomous Region, 2017; Executive Office of the People's Government of Xinjiang Uyghur Autonomous Region, n.d.).

${ }^{1}$ A brief note on the differentiation between China's minzu and ethnicity: The Chinese term minzu (民族)is often translated as nationality or ethnicity. Officially, the government of China recognizes $56 \mathrm{minzu}$, among which the Han is the national ethnic majority and the other 55 are minority ethnicity (shaoshu minzu，少数民族). Such division results from “the Minzu Classification (Minzu Shibie, 民族识别) - a major social-engineering project launched in the early 1950s by the Chinese Communist government" (Joniak-Lüthi, 2016, p. 2188). Many scholars debate the accuracy of the division. Some ethnic groups "were incorporated into one minzu" given the limited time to complete the Minzu Classification project and the political agenda backing it (Joniak-Lüthi, 2016, p. 2188; Becquelin, 2004). Adopting the "Soviet mode" of nationality identification, the minzu classification "aimed at creating, co-opting and controlling minority nationalities" and thereby creating a unified Chinese nationality and identify (zhonghua minzu, 中华民族) (Hess, 2010; Hao, 2015). 
Beneath the vast land lay abundant natural resources. With " $40 \%$ of coal reserve, $22 \%$ of petroleum reserve, and $28 \%$ of gas reserve in the country," Xinjiang is the pillar of China's energy production (Yin, 2015, p. 120). The primary and secondary industries ${ }^{2}$ revolving around the mining, processing, and production of natural resources, especially those of crude coal, oil, and natural gas, represent more than half of Xinjiang's Gross Domestic Product (GDP) (Statistics Bureau of Xinjiang Uyghur Autonomous Region, 2017). Plus, Xinjiang also provides China with a large deposit of rare earth and minerals that are crucial to construction and high-end technologies (Statistics Bureau of Xinjiang Uyghur Autonomous Region, 2017; National Bureau of Statistics of People's Republic of China, 2016).

In addition to its resources, Xinjiang's geographic location imparts economic and political significance because Xinjiang is China's gateway to Eurasia. Among all of China's provincial-level administrative regions, the XUAR has the most bordering states and the longest land borderline. Its territory touches that of Mongolia, Russia, Kazakhstan, Kyrgyzstan, Tajikistan, Afghanistan, Pakistan, and India. This location enables China to potentially "control... [the] geopolitical nexus between five great

\footnotetext{
2 Pursuant to the Industrial Classification for National Economic Activities (The General Administration of Quality Supervision, Inspection and Quarantine of the People's Republic of China; Standardization Administration of China, 2017), primary industry includes agriculture, forestry, and fishery; secondary industry includes energy and mineral mining and processing; and tertiary industry includes non-material production and services.
} 
cultural and geographic regions of Eurasia - China, the sub-continent, Iran, Russia and Europe" (Clarke, 2008, p. 90).

Figure 1 Location of the XUAR and Its Capital Urumqi in China and Eurasia ${ }^{3}$

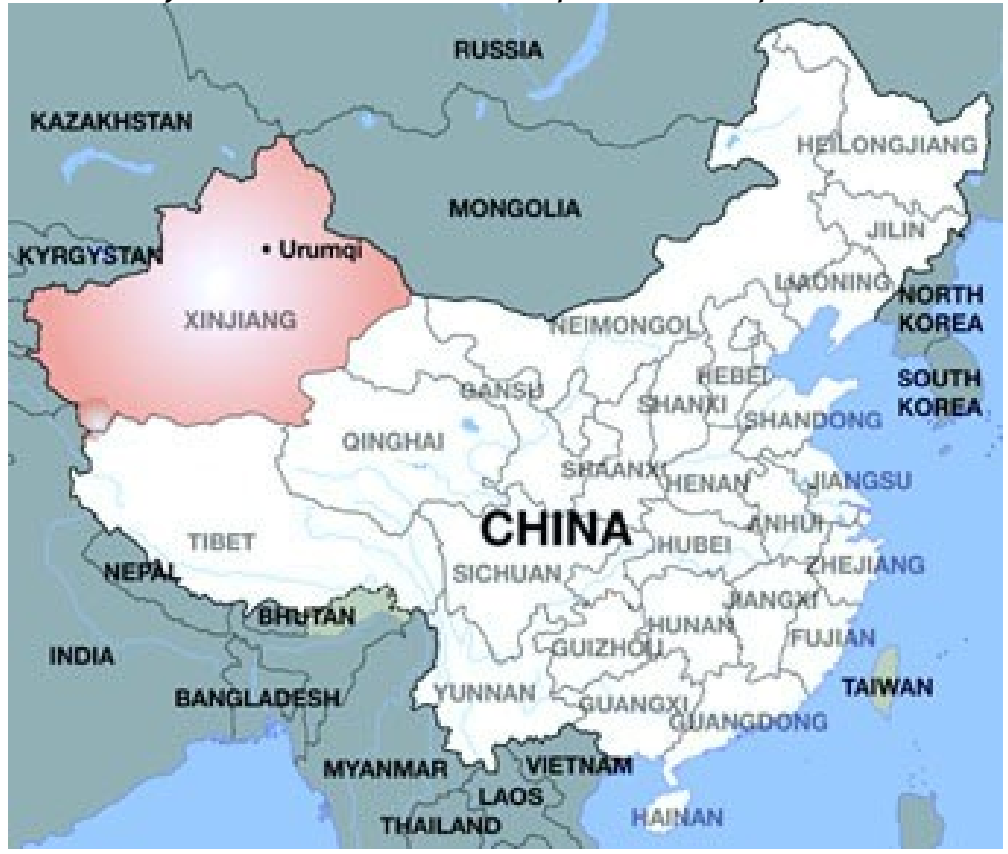

The market size and energy bonanza in Eurasia have long created opportunities for China's economy. Historically, Xinjiang was a main site of the Silk Road and other “East-West trading routes" (Dorian, et al., 1997, p. 2). At the end of the 1980s, the Soviet Union collapsed, allowing China to quickly enter this newly opened regional market and to establish economic ties with the post-Soviet states. Since then, China has enhanced its bilateral trade with Eurasian countries through Xinjiang, which was "almost non-existent

${ }^{3}$ Map credited to Oriental Review: Open Dialogue Research Journal (Oriental Review, 2013). 
[under the current regime] before the 1980s" (Dillon, 2003, p. 43). Bilateral trade with these countries has been growing steadily (Dorian, et al., 1997, p. 3). To date, SinoEurasian trades take up most of the imports and exports flowing through the custom checkpoints of Xinjiang. The volume of Xinjiang's imports and exports with its bordering countries is noteworthy: those with Kazakhstan, Kyrgyzstan, and Tajikistan alone take up more than $54 \%$ of the Xinjiang's annual total imports and exports (Statistics Bureau of Xinjiang Uyghur Autonomous Region, 2017). ${ }^{4}$

Following the Belt and Road Initiative (一帶一路) proposed by China's President Xi Jinping in the 2010s, Xinjiang showcases its significance again. Xinjiang has become the hub of a Silk Road Economic Belt (丝绸之路经济带) to reinforce China's access to the Eurasian market and its ties with the neighbours (Ministry of Foreign Affairs of the People's Republic of China, 2016). Given China's current challenges of domestic underconsumption and excess capacity (Pettis , 2013, pp. 96-99; Zhang, 2015), furthering the access to the Eurasia market is crucial for its continuous economic growth and internal political stability.

In addition to expanding market access, building and reinforcing ties with Eurasian countries also help China with securing energy resources, i.e. oil and gas. Now that domestic proven reserve and production of oil and gas are not sufficient to support

${ }^{4}$ Data extracted from database of Statistics Bureau of Xinjiang Uyghur Autonomous Region, calculation done by the author. 
China's rapid economic growth (Wei, 2008, p. 47), China must turn to foreign supplies "for more of the oil, gas, and coal it consumes" (Bergsten, et al., 2008, pp. 96-99). The International Energy Agency (IEA) predicts that by the 2030s, China will become "the biggest consumer of oil and [will have] a larger gas market than the European Union"; and by the 2040s, China's energy demand will double that of the United States (International Energy Agency, 2015).

The predicted growing demand of energy necessitates a diverse, safe, and stable access. In this case, many Eurasian states would be valuable strategic partners for China. Eurasia presents an alternative oil and gas reserve to the Middle East, as it is the second largest oil and gas reserve in the world (British Petroleum, 2017). In particular, Kazakhstan - one of the states bordering with China at Xinjiang - has 30 thousand million barrels proven reserve of oil, which is more than 4 times the reserve of Norway. Within the comparable reach like that from Xinjiang to Kazakhstan, Turkmenistan presents to China a known reserve of 17.5 cubic metres natural gas, which is more than half of the Russian reserve (British Petroleum, 2017).

Moreover, via Xinjiang, the transportation of oil and gas into China is closer and more reliable compared to traditional routes. At present, most of the transportation of oil and gas from the Middle East runs via ocean cargo. On this route, ships must travel through the Indian Ocean, the Strait of Melaka, and the South China Sea, which are areas that are vulnerable to blockades (Wei, 2008). The Strait of Melaka is an especially vulnerable chokepoint for oil transportation into China (U.S. Energy Information Administration, 2017). However, with the construction of pipelines - ideally, as China 
has proposed and been working on, a pipeline network covering and connecting Eurasia (People, 2014; Golovnina, 2007) - oil and gas can be pumping into China on a regular and reliable basis.

Figure 2 Ocean and Land Oil and Gas Transportation Routes 5

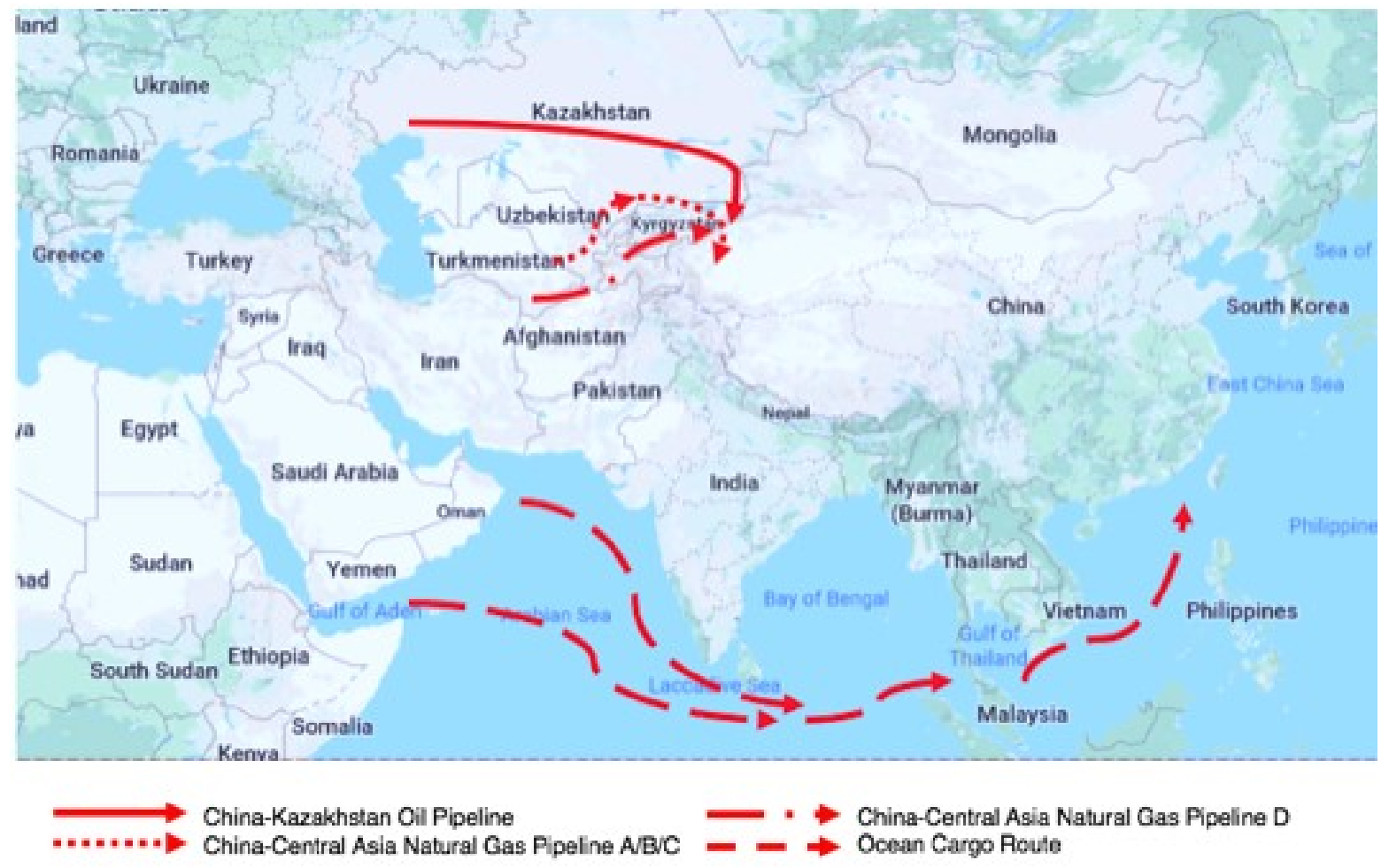

Along with the economic ties, this project also fosters China's political partnership with Eurasia (Dorian, et al., 1997). Whilst increasing China's influence in the regional and international politics, such political partnerships also serve a more tangible purpose: the pipeline network, as mentioned above, will not be feasible without being greenlit by the

${ }^{5}$ Map created by the author, based on information available from Ministry of Commerce of the People's Republic of China. 
states where the pipelines crawl. As such, state cooperation underpins the stable access to the energy reserve (Wei, 2008). It is thus not surprising that, similar to the market access, China seizes the opportunity to insert its political influence into the region when the control of the Soviet Union vanished (Kelkìtlì, 2014). In 2001, China led the establishment of the Shanghai Cooperation Organization (SCO), through which it cooperates with Kazakhstan, Kyrgyzstan, Russia, Tajikistan, and Uzbekistan on a wide-range of matter, including "politics, trade, the economy, research, technology and culture, as well as in education, energy, transport, tourism, environmental protection, and other areas" (The Shanghai Cooperation Organisation, 2017). U.S. embarrassments in its military interventions of the Middle East, as well as the distraction of the 2008 financial crisis, have offered yet other opportunities that China is seizing and steadily increases its influence in Central Asia (Kelkìtlì, 2014, p. 151). 


\subsection{Xinjiang's Challenges for China}

Nevertheless, China cannot access the advantages that Xinjiang offers - be it the connection to the national ethnic minorities, local energy reserve, access to Eurasian market and energy, or increased influences in Eurasia and thereby in global politics without facing the challenges in and from the region. Albeit China's official narrative on domestic and foreign affairs always declares that "Xinjiang has been an inherent part of [China's] territory since ancient times (新疆自古以来就是祖国不可分割的部分)" (Executive Office of the People's Government of Xinjiang Uyghur Autonomous Region, n.d.), Xinjiang's residents do not all agree.

Whereas Han is the dominant ethnicity in China, taking up more than $90 \%$ of the total Chinese population, non-Han ethnicities have long populated and outnumbered the Han in Xinjiang (National Bureau of Statistics of People's Republic of China, 2016). In the 1950s, more than $70 \%$ of Xinjiang's residents were Uyghur by ethnicity, which merited the establishment of the Uyghur Autonomous Region (Executive Office of the People's Government of Xinjiang Uyghur Autonomous Region, n.d.). Despite massive internal population flow for decades since the current regime took control of Xinjiang, on which the Chapter 6 will expound, nowadays the ethnic minorities still make up most of Xinjiang's population, of which $60 \%$ are non-Han and approximately $42 \%$ are Uyghur 6

${ }^{6}$ Calculated based on individual counts available in the annual report of China's National Bureau of Statistics. 
(Executive Office of the People's Government of Xinjiang Uyghur Autonomous Region, n.d.; National Bureau of Statistics of People's Republic of China, 2016).

For Uyghur who are native to the region, they share more ethnic and linguistic commonalities with the Turkic-speaking and Muslim populations of the adjacent Eurasian countries, rather than with the Han majority. In 1949, China's military, the People's Liberation Army (PLA), "peacefully liberate[d]" Xinjiang and thus incorporated Xinjiang into the territory of the current Chinese regime (Clarke, 2008, pp. 275-276). In the decades following the liberation, millions of Han people have relocated to Xinjiang from other parts of China, following state policies, mobilization, and organization. Therefore, in the eyes of the Uyghur, the Han are outsiders that only "recent[ly] immigra[ted]" to this area (Dorian, et al., 1997, p. 3). In the narratives of Western scholarship and diaspora literature, the "local ethnic populations, especially Uyghur, are the indigenous people in the region and largely the victim of Chinese rule historically, at least since the Qing conquest" (Zhu \& Blachford, 2016, p. 29). In reaction to the arrival of these recent immigrants emerges the Uyghur nationalism: "there is a growing consciousness of a Uyghur identity, especially in the Altishahr region 7 , which borders on Pakistan and Afghanistan and is where eighty per cent of Xinjiang's Uyghur" (Dillon, 2003, p. 24).

7 In Uyghur, Altishahr means "six cities," which refers to the area near the cities of Kashgar, Maralbexi, Aksu, Yengisar, Yarkand, and Khotan. 
In addition to the massive in-migration of Han population and the resulting grievances, some scholars, and at times official narratives ( People's Daily, 2013), point to Xinjiang's "porous western borders with Muslim nations" as an aggravating factor of the estrangement between the Uyghur and the Han (Tsuo, 2009, p. 10). The ethnic, linguistic, and geographic proximity of neighbouring Eurasian states expose Xinjiang and its residents to "Muslim extremism," which has resulted in historical instability of the region (Tsuo, 2009, p. 10). Spatially and psychologically distant from the rest of China, Xinjiang has challenged China with multiple "overt ethnic minority opposition[s]" in and from the area (Clarke, 2008, pp. 275-276). Believing that they should be a self-determined nation, some of the Uyghur have made violent separatist attempts (Hao \& Liu, 2012, pp. 213-214). When the possibility of independence is smothered, some Uyghur continue using violence to express their frustration. 


\subsection{The State's Responses and Results}

China has made many policy attempts to respond to these challenges. Since absorbing the XUAR into the Chinese territory in the 1950s, "rapid assimilation" had been the Chinese central government's policy guideline on the ethnic issues in the XUAR until the 1980s. The government established the Production and Construction Corps in Xinjiang (bingtuan and later XPCC for short) 8 , a state-owned, quasi-military, economic organization. It also encouraged the Han population to move into the XUAR, controlled and managed the religion and religious leaders, and co-opted the ethnic minority elites within the administrative apparatus (Ryono \& Galway, 2015).

Many of these policies and their products continue to be reinforced today, i.e. the XPCC, the encouragement of "Han in-migration", and the "control of ethnic minority religious and cultural practice" (Clarke, 2008, p. 278). Furthermore, since the end of the 1980s, the central government has strengthened its influence and power in decisionmaking regarding local economic affairs of the XUAR, especially in the excavation of natural resources and the development partnerships with adjacent post-Soviet Eurasian states (Zhao, 2001; Becquelin, 2000). It is also around the end of the 1980s that the underpinning idea of China's economic development strategy - economic prosperity in

8 For detailed differentiation of the forms of bingtuan and its evolution into XPCC please see Chapter 6. 
exchange for political stability - started taking shape, transforming into policies, and earning popularity among China's policy decision-makers (Zhao, 2008, pp. 47-50).

However, China's interethnic policies - what some scholars summarize as "repression, restriction, [and] investment" (Gladney, 2013, p. 118) - have yet ameliorated the situation to a satisfying level (Clarke, 2015). In the eyes of many Uyghur residing in the Xinjiang, the economic development strategy centres on "exploitation of mineral and other natural resources" (Dillon, 2003, p. 39) and is comparable to an "internal colonialism" (Ramachandran, 2017, p. 275). Some even portray the treatments of the region and, especially, of the Uyghur, as "a form of 'cultural genocide' at the hands of the Chinese state" (Clarke, 2008, p. 274). These policies have given "a perception [that the Uyghur] ethnic and cultural identit[ies] [are] being existentially threatened by the increasing dominance of Han Chinese within the bounds of their own 'autonomous region'"' (Clarke, 2008, p. 276).

Indeed, despite being officially named as an "autonomous region," the Uyghur in Xinjiang do not have much political autonomy. Key governmental positions in Xinjiang are stacked with communist party members who are under the central government's control. Since the current regime's takeover of the area to the present day, only 1 out of 10 of the Secretary of the Chinese Communist Party Committee of Xinjiang is Uyghur by ethnicity. This is significant since the Secretary of the CCP Committee of Xinjiang is de facto the highest position in the Chinese government on the provincial level (Han, 2010; Xinhua News Agency, 2016). 
Similar asymmetries can be found on the socio-economic front. Although Xinjiang's rich natural resources and booming Eurasian trade have brought it economic growth, the Uyghur have received uneven access to the beneficial results of development compared with the Han (Yin, 2015). Holding background characteristics constant, Zang (2010) finds that state-owned or state-backed workplaces hire significantly more Han than Uyghur individuals: Han individuals have almost double the chance in attaining jobs in state firms (p. 356). This illustrates Uyghur-Han economic discrepancies since state firms constitute the core of Xinjiang's economy and offer earnings 1.65 times higher than the private sectors do (Wiemer, 2004, pp. 174-175; Zang, 2010). As Figure 3 shows, in the same occupation, on average, state-owned and state-backed institutions offer significantly higher salaries than private companies. In addition, urban Uyghur are almost three times more likely to be hired in state firms (Zang, 2010, p. 359). Given that around $70 \%$ of Han and only around $20 \%$ of Uyghur in Xinjiang reside in urban areas (Li \& Chang, 2015, p. 30), it is evident that Uyghur in Xinjiang do not have equal job opportunities in state firms. 
Figure 3 Average Annual Income Discrepancy, Public and Private Industries in Xinjiang, $2015^{9}$

\section{Public/Private Income Discrepency}

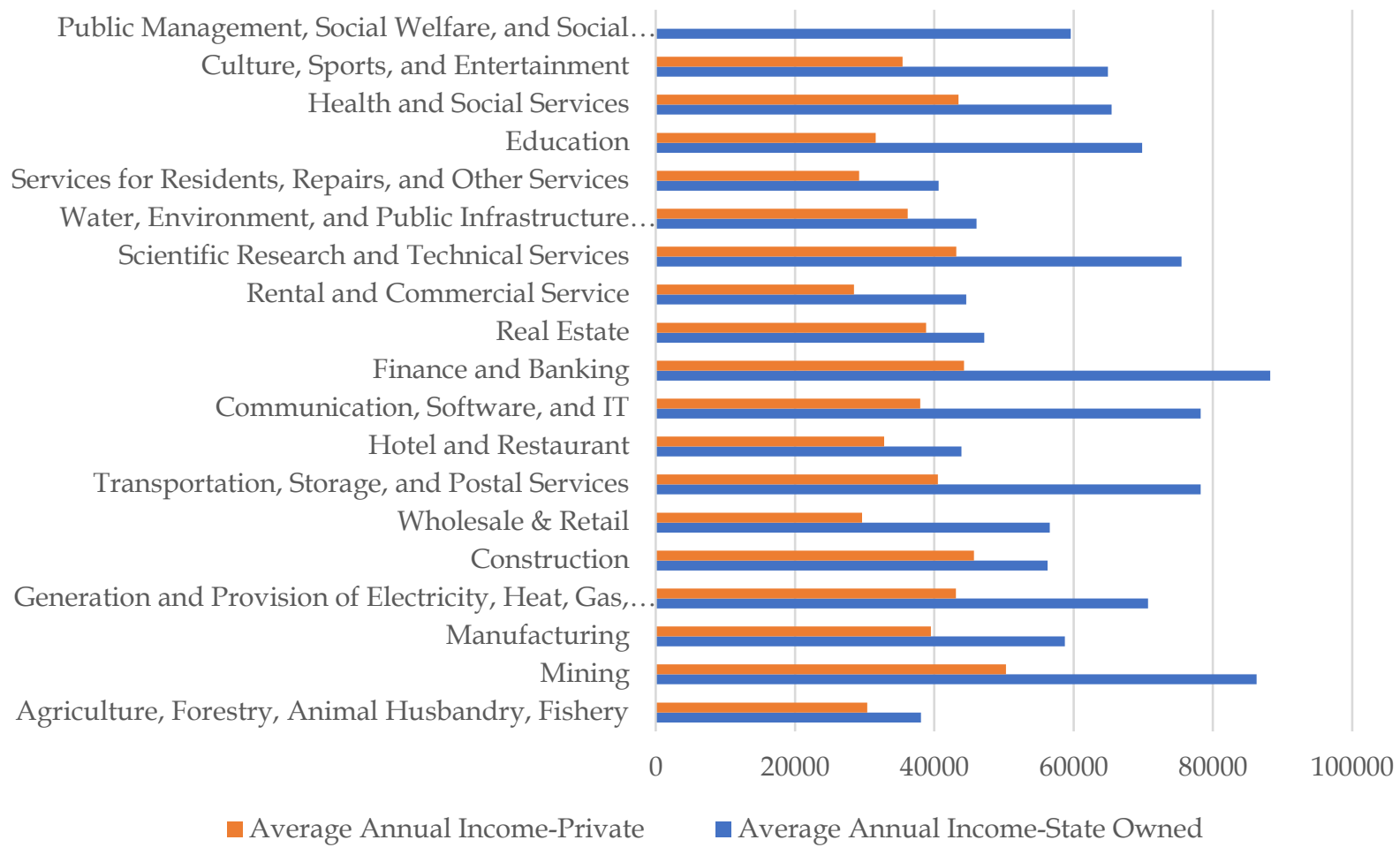

The Uyghur residents of the XUAR also work disproportionately in the primary industry. Around $82 \%$ of Uyghur in Xinjiang cluster in the primary industry. In comparison, around $32 \%$ of Han in Xinjiang work in the primary industry. These statistics displays a drastically different world between Xinjiang and the rest of China in terms of employment distribution across primary, secondary, and tertiary industries. Compared

${ }^{9}$ Bar graph created by the author per official economic statistics (Statistics Bureau of Xinjiang Uyghur Autonomous Region, 2017). The first category listed in the bar graph only presents the average annual income in state-owned units given the work related are government-run. 
with the rest of China, significantly more Uyghur and significantly fewer Han work in the primary industry in Xinjiang (Li \& Chang, 2015, pp. 28-29).

One should evaluate the significance of these employment patterns together with the noteworthy income gap among the three industries. On average, individuals employed in the primary industry receive $38070 \mathrm{RMB}$ (equivalent of approximately 7614 CAD) per year, whereas the average income in the secondary industry ranges from 58752 (in manufacturing sector, equivalent of approximately $11750 \mathrm{CAD}$ ) to $86253 \mathrm{RMB}$ (in mining, equivalent of approximately $17250 \mathrm{CAD}$ ) per year. In comparison, the average income in the tertiary industry has a low of 40614 (in repairing services, equivalent to approximately $8122 \mathrm{CAD}$ ) and a high of 88212 (in finance sector, equivalent to approximately 17642 CAD) (Statistics Bureau of Xinjiang Uyghur Autonomous Region, 2017). As demonstrated in Table 1, the industries in which more Uyghur people work have significantly lower income than in the industries where Han people work. Demonstrably, Han individuals are more likely than their Uyghur counterparts in Xinjiang to obtain positions that are better-paid, less labour intensive, and less demeaning. 
Table 1 Average Annual Income across Industries in Xinjiang, 2015, Details ${ }^{10}$

\begin{tabular}{|l|l|l|}
\hline \multirow{4}{*}{ Industry } & Occupation & $\begin{array}{c}\text { Average Annual } \\
\text { Income (RMB) }\end{array}$ \\
\hline \multirow{5}{*}{ Primary } & $\begin{array}{l}\text { Agriculture, Forestry, Animal Husbandry, } \\
\text { Fishery }\end{array}$ & 38070 \\
\hline & Mining & 86253 \\
\cline { 2 - 3 } & Manufacturing & 58752 \\
\cline { 2 - 3 } & $\begin{array}{l}\text { Generation and Provision of Electricity, Heat, } \\
\text { Gas, and Water }\end{array}$ & 70708 \\
\cline { 2 - 3 } & Construction & 56238 \\
\hline \multirow{5}{*}{ Tertiary } & Wholesale \& Retail & 56573 \\
\cline { 2 - 3 } & Transportation, Storage, and Postal Services & 78215 \\
\cline { 2 - 3 } & Hotel and Restaurant & 43885 \\
\cline { 2 - 3 } & Communication, Software, and IT & 78238 \\
\cline { 2 - 3 } & Finance and Banking & 88212 \\
\cline { 2 - 3 } & Real Estate & 47160 \\
\cline { 2 - 3 } & Rental and Commercial Service & 44595 \\
\cline { 2 - 3 } & Scientific Research and Technical Services & 75478 \\
\cline { 2 - 3 } & $\begin{array}{l}\text { Water, Environment, and Public Infrastructure } \\
\text { Management }\end{array}$ & 46068 \\
\cline { 2 - 3 } & $\begin{array}{l}\text { Services for Residents, Repairs, and Other } \\
\text { Services }\end{array}$ & 40614 \\
\hline & Education & 69813 \\
\cline { 2 - 3 } & Health and Social Services & 64906 \\
\hline & Culture, Sports, and Entertainment & 59598 \\
\cline { 2 - 3 } & $\begin{array}{l}\text { Public Management, Social Welfare, and Social } \\
\text { Organization }\end{array}$ & \\
\hline & &
\end{tabular}

While failing to address the interethnic discrepancies of employment and income prospects (Zang, 2010; Li \& Chang, 2015), many policies influence the Uyghur unfairly in

${ }^{10}$ Data retrieved from the Statistics Bureau of Xinjiang Uyghur Autonomous Region, 2017. 
social and cultural life. Since 2016, Xinjiang individuals have lost their rights to travel outside of the country now that the government has seized their passports. Critics argue that this seizure was without a legitimate basis (Human Rights Watch, 2016 ; Wong, 2016). Though targeting all Xinjiang residents, given the ethnic composition of the region, this measure disproportionately affects the Uyghur. Plus, other regions that are populated by the Han, as well as other ethnic minority autonomous regions ${ }^{11}$ are exempt from such a move. In addition, China has confiscated travel documents from Uyghur and Kazak residents in Xinjiang who have obtained residency of other states, as well as ordered Uyghur "currently living abroad are being ordered to return to China." Again, these measures, however, do not impact the Han Chinese (Qiao, 2017).

Besides public policy, discrimination against the Uyghur in everyday life is rampant as well. It is not uncommon that hotel proprietors reject business from clients whose national identification cards show their Uyghur ethnicity. It is common for Han people residing in mainland China to view the Uyghur as thieves, scammers, and barbarians (BBC Chinese, 2012; Yang, 2017). Official narratives also depict the ethnic minorities as backwards civilizations, who need the help of the ethnic majority, the Han, for "development and modernization" (Joniak-Lüthi, 2016, p. 2187). Demonstrably, ethnic minorities are perceived to be inferior in Xinjiang and throughout China.

11 Tibet Autonomous Region, Ningxia Hui Autonomous Region, Guangxi Zhuang Autonomous Region, and Inner Mongolia Autonomous Region. 


\section{Puzzle: Interethnic Violence on the Rise}

\subsection{Tabulation of The Uyghur-Han Conflicts}

Interethnic differences, coupled with unfair policies and their consequences, have brewed the Uyghur community's collective fear and resentment of the Han dominance. Consequently, the open clashes between the Uyghur and the Han have been growing at an accelerated pace. The author has tabulated the Uyghur-Han public violence that occurred from 1980 to 201712, with cross-references to academic sources (Clarke, 2015; Chen, 2009; Zhang, 2009; Fearon \& Laitin, 2011; Wang, 2015; Shanghai Office of Local Chronicles, n.d.) and major media outlets, including Radio Free Asia, BBC, Radio France

Internationale, 人民网 (People), Phoenix News, etc. ${ }^{13}$ By consulting peer-reviewed academic publications, Chinese and international news source of eclectic political stances and cultural backgrounds, the author strives to avoid a skewed result and to provide as neutral a view as possible. Table 2 chronicles the public violent incidents.

${ }^{12}$ Given the documentations prior to the year 1980 is more difficult to obtain in such a way to provide meaningful comparison, and that this study focuses on EDS-related policies, which starts in the late 1980s/early 1990s as Chapter 6 discusses, the author limits the tabulation to the period of 1980-2017. The data of the early 1980s are included to show prior conditions.

${ }^{13}$ List last updated November 20, 2017. 
Table 2 Uyghur-Han Violent Incidents within China, 1980-Present, Chronicled ${ }^{14}$

\begin{tabular}{|l|l|l|}
\hline Onset Date & Location & Description of the Incident \\
\hline $1980-04-09$ & Aksu & Riots against Han \\
\hline $1981-01-13$ & Yecheng, Kashgar & Riot and attacks on police and government \\
\hline $1981-05-27$ & Kashi, Kasghar & Insurgency \\
\hline $1981-10-30$ & Kashgar & $\begin{array}{l}\text { Riots and attacks on streets and police and } \\
\text { government }\end{array}$ \\
\hline $1985-12-12$ & Urumqi & $\begin{array}{l}\text { Riots against cadre shifts and Han ruling and } \\
\text { dominance }\end{array}$ \\
\hline $1988-06-15$ & Urumqi & Riots in reaction to insulting graffiti \\
\hline $1989-05-19$ & Urumqi & Riots against sexual publication and Han ruling \\
\hline $1989-05-22$ & Qorghas, Illi & Riots (prompting XPCC to revive) \\
\hline $1990-04-05$ & Baren, Akto & Riots \\
\hline $1991-02-28$ & $\begin{array}{l}\text { Kuqa } \\
\text { County,Aksu }\end{array}$ & Bombing of a video theatre \\
\hline $1992-02-05$ & Urmuqi & Bombing of two buses \\
\hline $1993-06-17$ & $\begin{array}{l}\text { Kashgar } \\
\text { Hotan }\end{array}$ & $\begin{array}{l}\text { Explosions at department stores, markets, hotels, } \\
\text { and "places of cultural activities" }\end{array}$ \\
\hline $1993-06-17$ & Yecheng, Kashgar & Explosions \\
\hline $1995-07-07$ & Hotan & $\begin{array}{l}\text { Attacks on government building and police } \\
\text { stations }\end{array}$ \\
\hline $1996-08-27$ & Yecheng, Kashgar & Attacks on government office building \\
\hline $1997-02-05$ & Yining, Kulja & Riots \\
\hline $1997-02-25$ & Urmuqi & Bombing of three buses \\
\hline $1998-04-07$ & Yecheng, Kashgar & Explosions \\
\hline $1998-05-23$ & Urmuqi & Arson, public markets \\
\hline $1999-10-11$ & Khotan & Arson, public markets \\
\hline $1999-10-24$ & Zepu, Kashgar & Attacks on police station \\
\hline $2008-08-04$ & Kashgar & Bus crashing and knife attack \\
\hline $2009-07-05$ & Urumqi & Riots \\
\hline $2010-08-19$ & Aksu & $\begin{array}{l}\text { Attacks on government offices and holding } \\
\text { hostages }\end{array}$ \\
\hline $2011-07-18$ & Hotan & Carjack, crashing, and knife attacks \\
\hline $2011-07-30$ & Kashgar & Knife attacks \\
\hline $2012-02-28$ & Yecheng, Kashgar \\
\hline $2012-10-01$ & Yecheng, Kashgar & Bombing \\
\hline & & \\
\hline 19
\end{tabular}

14 Table compiled by author, for further details, please contact the author for the raw data file. 


\begin{tabular}{|l|l|l|}
\hline $2013-03-07$ & Korla & Knife attacks \\
\hline $2013-04-23$ & Seribuya, Kashgar & Attacks on police and community worker \\
\hline $2013-06-26$ & Turpan & $\begin{array}{l}\text { Attacks on police station, government building, } \\
\text { and construction site }\end{array}$ \\
\hline $2013-06-28$ & Hotan & Group unrests \\
\hline $2013-10-28$ & Beijing & Deliberate car crash \\
\hline $2013-11-16$ & Seribuya, Kashgar & Knife attacks \\
\hline $2013-12-15$ & Kashgar & Open clashes, storming of police stations \\
\hline $2013-12-30$ & Yarkand, Kashgar & Knife and explosives attacks at police station \\
\hline $2014-02-14$ & Aksu & Attacks on police \\
\hline $2014-03-01$ & Kunming, Yunnan & Attacks at train station and passengers \\
\hline $2014-04-30$ & Urumqi & Knife attacks and suicide bombing of train station \\
\hline $2014-05-06$ & Guangzhou & Attacks of train station and passengers \\
\hline $2014-05-22$ & Urumqi & Car crashing and bombing \\
\hline $2014-06-15$ & Hotan & Knife attacks \\
\hline $2014-06-21$ & Yecheng, Kashgar & Bombing of police station \\
\hline $2014-07-08$ & Aksu & Knife attacks of Han peasants \\
\hline $2014-07-28$ & Yarkand, Kashgar & Mass knife and axe attacks \\
\hline $2014-09-21$ & Bayingol & Bombing of markets and police stations \\
\hline $2014-10-12$ & $\begin{array}{l}\text { Maralbelxi, } \\
\text { Kashgar }\end{array}$ & Knife attacks and bombing of market \\
\hline $2015-02-16$ & Guma, Hotan & Attempted bombing \\
\hline $2015-03-06$ & Guangzhou & Attacks of train station and passengers \\
\hline $2016-12-27$ & Karakax, Hotan & $\begin{array}{l}\text { Knife attacks and bombing of government office } \\
\text { building }\end{array}$ \\
\hline $2017-02-15$ & Guma, Hotan & Knife attacks \\
\hline & & \\
\hline
\end{tabular}




\subsection{Conflict Patterns and Motivation of Research}

In total, there are 51 verifiable open clashes between the Han and the Uyghur during 1980-2017. Close to 55\% of the Uyghur-Han violence in the past four decades occurred within the past decade. Figure 4 vividly displays a hike in conflict frequency after 2010.

The relative concentration of conflicts within the past decade is astonishing, since the Xinjiang's GDP and its residents' real income have been in steady annual increase during 1980-2017 (Statistics Bureau of Xinjiang Uyghur Autonomous Region, 2017). In summary, if China's "prosperity for peace" tactic was successful, then the past decade should have seen a decrease in conflicts instead of such an accelerated rate of conflict onset growth.

Figure 4 Uyghur-Han Violent Incidents within China, 1980-Present, by Year

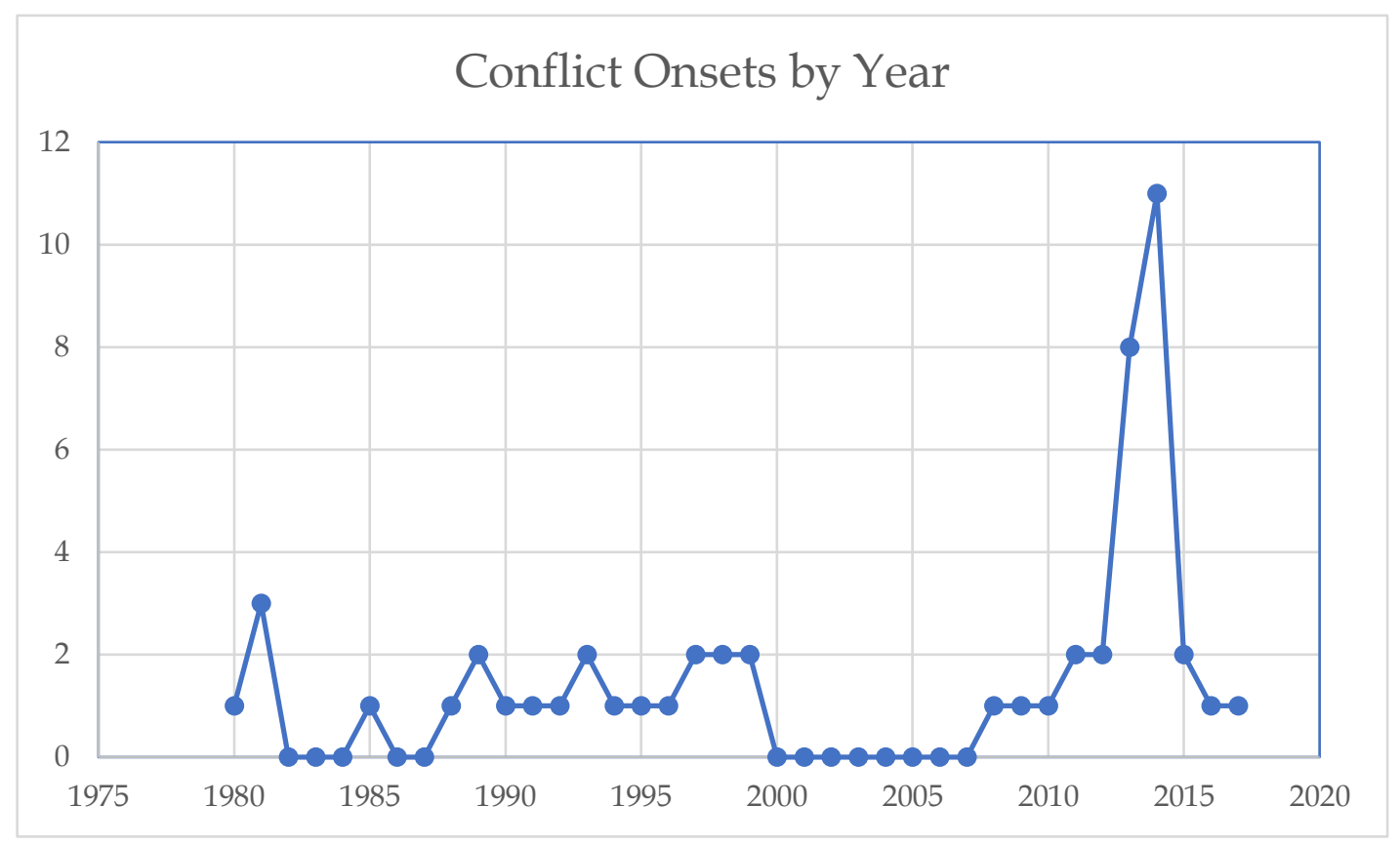


Why have the policy outcomes strayed so far from policy prescriptions? To solve this puzzle, one must first understand the nature of the conflicts. Detailed in the description column in Table 2, almost all violent incidents contain appeals for selfdetermination against the Han, including their dominance and mistreatment of the Uyghur people. These incidents fall into three categories by location. As shown in both Table 2 and Figure 4, a quarter of the violent incidents took place in a designated political capital, i.e. Kunming (the capital of Province of Yunnan), Guangzhou (the capital of the Province of Guangdong), Urumqi (the capital of the XUAR), and Beijing (the capital of China). These incidents follow the patterns of typical terrorist activities: they are premediated, organized attacks of civilians. Political capitals are favoured conflict locales since they possess the conditions to help better deliver symbolic political messages for violent incidents that are the catharsis of the participants' frustrations. Being the social, economic, and political hubs, a capital by nature attracts more attention. Additionally, the large population residing in a capital city provides the ground for easier mobilization and means a potentially higher count of casualties, which helps elevate the attention needed. A large population also increases the potential of inter-group disagreements that can escalate into open clashes. These disagreement-turned clashes sometimes transformed into a site of grievance expression as well. For instance, the Urumqi $7 / 5$ riots was instigated by the bickering between Han and Uyghur factory workers and eventually exploded into riots (Millward, 2009). 
Besides in the capitals, the majority of the tabulated violent incidents have taken place in the southern ${ }^{15}$ and poorer part of the XUAR. ${ }^{16}$ This area largely overlaps with the Altishahr region, where most Uyghur reside, and, as previously discussed in Chapter 2, where Uyghur nationalism is growing in reaction to Han dominance. Northern Xinjiang, the more "industriali[z]ed [part] with many large cities devoted to such modern industries as oil refining" (Dillon, 2003, p. 4) where Han people outnumber the Uyghur (Joniak-Lüthi, 2016, pp. 2191-2192) have significantly fewer open clashes.

Figure 5 Uyghur-Han Violent Incidents within China, 1980-Present, by Location

\section{Conflict Onsets by Location}

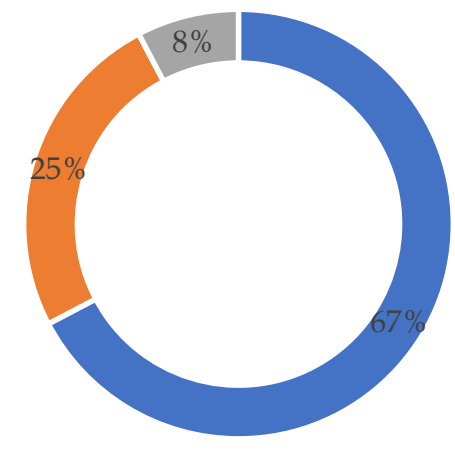

- Southern XUAR = Capital = Other

${ }^{15}$ Traditionally, the area of the XUAR which is south of the Mountain of Heaven (天 山)is known as Southern Xinjiang (南疆).

16 The gap of economic development between Northern and Southern Xinjiang can be reflected in the government's agenda, for example the meetings of the Party Committee of the XUAR of the Communist Party of China (CPC) (Yao, et al., 2015). 
Categorizing the conflicts by their onset locations helps reveal some important characteristics of the Uyghur-Han conflicts. They are open clashes initiated by the Uyghur against the Han population, motivated by opposition to Han dominance. Except for planned terrorist-type attacks, these conflicts frequently occur in locations where the Uyghur population outnumber the Han. In other words, the local ethnic majority attacks the in-migrant national ethnic majority. This marks the key difference between the Uyghur-Han conflicts and traditional interethnic violence: in the Uyghur-Han conflicts it is the national ethnic minority who try to drive out the majority by violent means.

So far, the discovered patterns of the Uyghur-Han conflicts have strongly motivated this study. The conflict patterns have not only countered the economic development strategy (EDS), but have also shown trends uncommon in traditional ethnic conflicts. Under such circumstances, it is important to investigate the policy efficacy of the EDS, and as importantly, to reflect on whether extant theoretical frameworks are sufficient in the studies of developmental policies and interethnic conflicts. 


\section{Theoretical Framework: The "Sons of the Soil" Conflicts, Feminist Political \\ Economy, and Interethnic Policy Analyses}

\section{1 "Sons of the Soil" (SoS) Conflicts}

\subsubsection{Defining SoS}

Weiner (1978) first coined the term the "Sons of the Soil (SoS)" conflicts when studying the "anti-immigrant and nativist movements" in post-independence India (Côté \& Huang, 2017, p. 3). The concept reinvigorates and expands its influence almost three decades after its debut, as Fearon and Laitin (2011) use it in their research on global civil war developments. Today, the concept of SoS conflicts is developed to capture the intrastate, migration-related, interethnic violence that:

"...involves an insurgent band fighting on behalf of an ethnic minority on the periphery of a state dominated by another ethnic group; against the state's military or paramilitary formations, and/or members of the majority group who have settled as farmers in the minority group's declared home area; and involves either land conflict with migrants from the dominant group or conflict over profits and control of fuel or mineral resources in the minority's home area... [with a limit] to those where migration is an issue... [also with an expansion] to include cases where the competition is over things beside farm land" (2011, p. 200)

In a typical SoS conflict, there are two belligerent groups. The first group is an ethnic minority. Members of this group have been living on the same land for generations and consider themselves the natives "of the soil" and thus the righteous owners of the land and its resources. The second group is the ethnic majority from the same country. They migrate to the area where the ethnic minority group lives. As the two groups 
compete over land, the resources thereon, and the interests incurred, an SoS conflict ensues (Weiner , 1978; Fearon \& Laitin, 2011; Côté \& Huang, 2017).

SoS conflicts share in common four conflict dynamics: 1) migration of the ethnic majority group, which is "often encouraged by state policy"; 2) the hostilities and "lowlevel violence" between the migrant group (also the ethnic majority of the country) and the local group (also the ethnic minority); 3) police intervention, the success of which depends on the capacity of the state; and 4) the state supporting one side (Fearon \& Laitin, 2011, pp. 204-206). In sum, ethnicity, indigeneity, and migration are three key components of SoS conflicts.

Recent years' conflict and SoS literature adopts the concept of Horizontal Inequalities (HIs) to capture inter-group inequalities and their contribution to conflicts. A concept led by Frances Stewart (2008), HIs capture the social, economic, and political inequalities between target groups. In detail:

"Political HIs consist of inequalities in the group distribution of political opportunities and power, as measured by a group's control over or exclusion from - the presidency, the cabinet, parliamentary assemblies, the security forces, and regional and local government. Socio-economic HIs include inequalities in ownership of assets, income and employment opportunities. They also include access to a wide range of services such as health and education, and inequalities in achievements in health and educational outcomes. Finally, cultural HIs include the extent to which a society recognizes (or fails to recognize) a group's cultural practices. and thus explains the group actions against another." (Côté, 2015, pp. 359-360)

Stewart (2008) also finds that the greater the HIs, the greater potential there are for conflicts between the groups. As the actors, patterns, and dynamics in the Uyghur-Han conflicts are highly identical with the definition of those of the SoS cases, the analytical 
tools can help exploring the inefficacy of the economic development strategy and relevant policies that China imposes on the Uyghur.

\subsubsection{Understanding the Significance of SoS}

Although initially introduced to describe open clashes in India, today the concept of the SoS conflicts is widely applicable (Cohen, 1981). The booming literature speaks to the prevalence of the SoS conflicts: they have been studied in Sri Lanka (Tambiah, 1986), Indonesia (Anata, 2006) , Republic of Congo (Jackson, 2006), Côté d'Ivoire (Mitchell, 2012), former Soviet States (Kolsto \& Blakkisrud, 2013), and China (Côté, 2015). Fearon and Laitin (2011) tabulate more than 22\% of all the civil wars after 1945 as SoS conflicts. Concurring with Weiner (1978) who argues that SoS conflicts are "potentially explosive" (Côté, 2011, p. 1856), Fearon and Laitin (2011) also predict that the influence of the SoS conflicts will be on the rise. More recent studies corroborate: of all countries and all type of regime, none is exempted from the SoS conflicts (Côté \& Mitchell , 2017; Côté \& Huang, 2017).

The concept of the SoS conflicts is important for not only its wide applicability, but also the complexity. Innate to its concept, the SoS conflicts combine the challenges of ethnic divide, migratory population flows, territorial disputes, socio-economic inequalities, and power struggles. These challenges channel through two layers of identity opposition: the locals against the outsiders, and the ethnic minority against the majority. Any single one of these challenges on any of the two identity oppositions would 
have been disruptive to regional stability and prosperity, let alone compounding all of them. Such complexity of the SoS conflicts entails richness in relevant studies.

The concept of SoS conflicts departs from the emphasis on ethnicity when studying similar conflict cases and can thus be useful in the analysis of EDS policies and the Uyghur-Han conflicts. Extant ethnic conflict literature defines ethnicity in multiple ways. For premodialists, ethnicity is "deeply rooted in historical experience" (Cordell \& Wolff, 2009, p. 15). In contrast, constructivist and instrumentalists see ethnicity as a tool. Open for manipulation, ethnicity and its definition can be used to mobilize participation and therefore to promote interests for certain groups (Cordell \& Wolff, 2009, p. 15; Lake \& Rothchild, 1998, p. 5). Ethnicity can be determined by tangible characteristics like physical appearance, or intangible characteristics like religion, culture, and common practices (Young , 1976; Smith, 1991; Kaufman, 2001). With the varying and even at times contrasting definitions of ethnicity, ethnic distinctions can at best partially account for the mobilizations of conflicts (Wolff, 2006). Specifically, in the case of China's Uyghur-Han conflicts, there is emerging scholarship whether the "ethnic narrative [is] enough to explain" the clashes (Cote, 2015; Ryun \& Galway, 2015).

Indeed, a growing literature suggests that ethnicity alone is no longer sufficient in explaining the outbreaks of contemporary ethnic conflicts. Distribution and redistribution of resources in the realms of politics, economic, health, environment, personal, and community play an important role (Baker, 2010; Sunga, 2014). Studies on ethnic conflicts in other parts of the world also corroborate. For instance, in the Rwanda genocide, instead of their physical, cultural, religious, or practical ethnic differences, at 
the root of the hostilities is the Tutsi's political and socio-economic upper-hand enabled by the Belgium colonizers justified by their perception of ethnic distinctions. Many scholars have argued that these distinctions are constructed (Baisley, 2014; Baines, 2003). Similarly, in the Sudan genocide, at the core of the opposition between the indigenous African and the Arab populations is the access to oil and its profits, rather than the ethnic differences themselves (Hannibal, 2008). Undoubtedly, at other times ethnic groups clash to protect their survival. Yet, deep down, it is the threat to social, economic, and political means that impedes the groups' survival that is the root cause. Therefore, in essence, to defend an ethnic group's security is to defend its power and resources (Clarke, 2008).

"In practical terms, the need for policy to ameliorate ethnic conflict has come close on the heels of the need for theory to explain it and to elaborate its many patterns" (Horowitz, 1985, p. 12). When the theory only enables a partial explanation, the policy prescription based thereon to prevent and intervene in conflicts will arguably be sub-par. Now that the Chapter 2 has informed one that the Uyghur-Han conflicts are more than the rivalry of ethnic identities, studying these conflicts under the SoS framework departs from the emphasis on ethnicity that can at best offer partial explanation of conflicts, and allows one to incorporate equally important explanatory factors. Consequently, one can better capture conflict causal mechanisms, and thereby understand how the EDS-related policies fail to address the interethnic hostilities, and provide more efficient policy prescription.

To be clear, adopting the concept of SoS conflicts does not deny the significance of ethnicity. The SoS conflict concept shifts the heightened focuses from ethnicity to 
encompass the interaction among ethnicity, resources, and authority. Thus, compared with traditional ethnic conflict studies, the concept of the SoS conflicts explores the conflict causal mechanisms in a more comprehensive manner, thus reveals the big picture, brings us closer to the root causes, and hopefully allows us to discover more effective solutions that integrate expertise across different but correlated disciplines.

The aftermaths of the SoS conflicts are also noteworthy. Studies have well demonstrated the "grave consequences" of ethnic conflicts (Wolff, 2006, p. 4). They are immense menaces to human rights and state cohesion (Wolff, 2006; Welsh, 1994; Horowitz, 1985; Brown, 1994). In addition to the ethnic components, SoS conflicts also have characteristics that are common to intra-state conflicts, which are more frequent than inter-state wars today (Murshed, 2005, p. 76). As intra-state conflicts have track records of "spilling-over" and impacting the security and stability of neighbouring states, SoS conflicts also pose threats to inter-state peace and international stability (Tilly \& Tarrow, 2015; Tarrow, 2005).

Further complicating such menaces from ethnic and intra-state conflicts are the impacts of large-scale internal migration. Totalled four times the number of international migrants (United Nations Development Programme, 2009), internal migrants move with their impacts. When migrants move, they refresh their perceptions of their identities in the family, in the workplace, and in the home and host communities. Changing perceptions of identities disrupt the traditional social structure and gender relations, and then destabilize the original constitution and order of the communities (Peterson, 2003, p. 68). As a result, conflicts break out. Whereas these conflicts can manifest in various 
forms - i.e. "anti-immigrant racism, nationalist state building, ethno-cultural diaspora, ethnic cleansing, or patriarchal religious fundamentalism" (Peterson, 2010, p. 180) - the Uyghur-Han conflicts, as well as other SoS cases by definition, burst in an untraditional way. The hostilities are not simply between the dyads of locals and immigrants, that of the men and women, or that of the ethnic majority and the minority, but the combination of all. Additionally, internal migration is not a one-direction, linear process "constituted by a permanent move from one nation to another" (Nyíri, 2005). Neither are its influences. As such, the above illustrated impacts of internal migration can influence and be influenced by each other, circulating among the diaspora, the home, and the host communities. In this way, understanding and curbing the impacts of Uyghur-Han conflicts and similar SoS cases, which are reactive, continuous, multi-dimensional, and multifaceted, have become even more complex (Nyíri, 2005; Côté \& Huang, 2017).

With technological advancement in communication and transportation, as well as decrease job stability and widening wealth gap, internal migration is expected to continue to grow. Especially, Asian states will see their population's mobility increase at an "unprecedented scale", with most population flowing out from "underdeveloped"

communities (Deshingkar, 2006, pp. 88-91; Ritzer, 2010). Against this backdrop, the significance of SoS conflicts and the study of them are demonstrable.

\subsubsection{Differentiating SoS, Ethnic Conflicts, and Civil Wars}

Given the ethnic and intra-state characteristics, SoS conflicts are often categorised under studies of either ethnic conflicts or civil wars (Côté \& Mitchell , 2017; Fearon \& 
Laitin, 2011). Despite their similarities, it is crucial to grasp the uniqueness of the SoS conflicts and thereby recognise the limits of ethnic conflict and civil war literature in application on SoS conflict analysis.

To recapitulate, as in traditional ethnic conflict studies, ethnicity is an important component of SoS conflicts. Yet, the studies of SoS conflicts focus on the nexus between ethnic identities and contestations of power and resources, instead of on ethnicity itself alone. The inconsistent definition of what constitutes an ethnicity renders the explanation of conflict mobilization that builds purely on ethnicity incomprehensive. In this case, moving away from the heightened focus of ethnicity helps us better understand the grounds of conflict mobilization, the underlying cause of the conflicts, and therefore the overall conflict causal mechanisms. Consequently, a better understanding of SoS conflicts allows us a better policy prescription to prevent and intervene similar migration-based interethnic clashes.

More importantly, in SoS conflicts, ethnicity has significantly less influence in conflict organizations. To begin with, ethnic identity is not the sole determinant of group inclusion. Unlike in standard ethnic conflicts, it is common that the ethnic boundary is crossed in SoS conflicts. The ethnic minority group welcomes and includes people of other ethnic identities in participating the contentious events. Those who are welcomed and included also genuinely associate themselves with the ethnic minority group albeit their ethnic characteristics. In SoS conflicts, the local, ethnic minority often unite with the earlier migrants, whatever their ethnic identities are, against the new-comers of national ethnic majority (Cote, 2015; Côté, 2014). 
Neither does ethnicity alone determine the hostile relationship in SoS conflicts. Not all ethnic groups that migrate to the region are equally susceptible to SoS conflicts (Peluso, 2008; Côté \& Mitchell , 2017). Whereas traditional ethnic conflict studies emphasize the contribution of ethnic identities to conflict causal mechanisms, in SoS conflicts ethnicity matters only when interpreted together with indigeneity. In SoS conflicts, interethnic clashes do not occur between groups that have co-habit in a troubled region for generations but between native groups and new-comers.

Eventually, an SoS conflict is more about who "[is] here first" (Geschiere \& Jackson, 2006, p. 5). In this case, approaching SoS conflicts as though they were traditional ethnic conflicts will overemphasize the impacts of ethnicity and downplay other essential contributing factors. Arguably, in the Uyghur-Han cases, treating the conflicts as though the ethnic identities are the sole, key causes will hinder one's precise capture of the conflict dynamics and causal mechanisms. Without the proper understanding of the Uyghur-Han conflicts, there will not be a meaningful analysis of the efficacy of the economic development strategy.

Equally problematic is approaching SoS conflicts as though they were civil wars. SoS conflicts are not compatible with the commonly adopted definition of civil war in the literature. Generally, scholars recognise a civil war when there are at least 1000 deaths, with at least 100 annual fatality count (Singer \& Small, 1982; Fearon \& Laitin, 2003; Paul \& Anke, 2006), or, when the country has a small population, a comparable a per capita death toll (Sambanis, 2004). Although fatalities can be present in SoS conflicts, it is not 
indispensable. Even when present, fatalities in SoS conflicts are most of the time at a significantly lower degree, unlike in civil wars (Peace Research Institute Oslo, 2016).

In addition, at least 100 people must be killed on both sides of the conflict (Fearon \& Laitin, 2003). Yet, in SoS conflicts usually the ethnic minority group attacks the ethnic majority group, and seldom the other way around. Understandably, not even the total fatalities but also the death count on each side - especially the side that initiates the contention with numerical superiority - are too low to meet the civil war definition. SoS conflicts also tend to last longer than civil wars (Mukherjee, 2014). As such, unlike in civil wars, SoS conflicts do not have milestone events as apparent as in civil wars, i.e. open fire, ceasefire, peace talk, disarmament, etc. that can serve as a short hand with which one marks the beginning and the end of a contention.

Given the incompatibility of SoS conflicts and the operational definition of civil wars, it is not surprising that major conflict database - i.e. Correlates of War Projects (COW), Stockholm International Peace Research Institute (SIPRI), Peace Research Institute Oslo (PRIO) - lack the quantitative information of SoS conflicts. For example, most of the conflict cases coded in Table 2 are not reflected in any conflict database. Unfortunately, recalling the SoS definition, the state backs one of the rivalry parties, and thus the conflicts would not be reflected in major media either due to state censorship 
and repression. ${ }^{17}$ It is concerning that SoS conflicts have been largely ignored and therefore afforded less research focus and efforts because it has not caused high enough fatalities. However, as manifests in the tabulation of the Uyghur-Han conflicts, although the injuries are not as jaw-dropping as civil wars, the incessant trauma to the people and the region is too agonizing to ignore.

Even when certain data projects incorporate SoS conflicts, they are coded with inconsistency and thus cause confusion. Such inconsistency and confusion are largely attributed to treating SoS conflicts as civil wars. The vague initiation and cessation timeline, along with the prolonged conflict time, makes coding SoS conflicts following civil war criteria not fruitful. Controversies arise and affect practices. Whether to code several conflicts in association as one SoS event or several separate ones is not as clear as in civil war, where several battles in reaction to each other can be coded under one civil war. For example, a series of Pakistani contentious events spanning over two years are coded as one SoS case by Fear on and Laitin (2011), whereas they are coded as two separate cases in the battle death database of PRIO (Peace Research Institute Oslo, 2016). Yet, three Soviet SoS cases occurred in the same year are coded separately, whereas they are entered as one in the PRIO database. Such inconsistency makes the counts of onset and fatalities unreliable: coding several events as one, the count of onsets decreases and

17 A case in point of state censorship in the Uyghur-Han conflicts is that 13 of the 16 authors of the scholarly publication Xinjiang: China's Muslim Borderland are prohibited from entering China (Chen, 2012). 
the fatalities increase. This influences the meaningfulness of quantitative studies. In all, due to the lower fatality and longer duration, studying SoS conflicts with the incompatible civil war definition and operation will lead to the neglect of many cases and cause confusion in databases and literature.

Moreover, neither studies of ethnic conflicts nor civil war stress the importance of land and migration as the concept of SoS conflicts merits. Innate to the definition, land and migration are two necessary conditions of SoS conflicts. In ethnic conflict or civil war literature, although these two factors are at times studied, i.e. for their influence on conflict mobilization and participation (Do \& Iyer, 2009; Weidmann, 2009), land and migration are not seen as indispensable in the conflict causal mechanism (Côté \& Mitchell, 2017). Nevertheless, among the main appeals that motivates the open clashes are the Uyghur's resistance to the Han migration and eclipse of the land and resources. Lacking the analysis of these two necessary factors, the probing of the economic development strategy will not be convincing. 


\subsection{A Feminist Political Economy (FPE) Approach to Conflicts}

\subsubsection{The Influences of Gender Stereotypes on Conflict Organization}

A large body of literature in both conflict studies and feminist studies has effectively reflected how gender - or more precisely, gender stereotypes - influence contemporary conflicts. Chinkin and Kaldor (2013) identify a dichotomous view of men and women in conflicts: in the popular perspective, men are the "protector[s]" and women are the "protected" (168). Common narratives depict men as more competent in combating (Annan, et al., 2011). In comparison, women are the victims of violence (Turshen, 2016; Meger, 2015; Kirby, 2013). Whereas men fight in the conflicts (Pankhurst, 2008), women run anti-violence campaigns and peace-building processes, since the public see them as more peaceful and thus better suited for the tasks (Bryant-Tarpeh, 2012; Henshaw, 2017).

Such gender stereotypes are consistent among different types of conflicts and across different cultures since the $18^{\text {th }}$ century (Goldstein, 2001). Albeit enduring and widely held, current scholarship has debunked such biases with detailed examinations of these conflicts and relevant policy-making processes. Enloe (2007) argues that conflicts are not only male activities and that women represent an essential component as well. Throughout the history, there have been female combatants in numerous conflicts (Goldstein, 2001, pp. 64-83). Females have always been in the picture of militarization "at home, nationally, and globally" (Enloe, 2007, pp. 158-159). Contrary to common beliefs, empirical studies have shown that female actors are not more peaceful than male actors (Caprioli \& Boyer, 2001; Lu \& Breuning, 2014). There is no genetic predisposition for male 
to be more prone to war. Neither do women have more propensity for peace either (Goldstein, 2001, pp. 182, $250 \& 405)$.

Nevertheless, these stereotypical views have earned so much popularity that has enabled gender to be a determinative factor on power and resource distribution during conflicts (Sjoberg, 2013). Accordingly, "sex-based characteristics" have become "not only ... a constraint on actor's behavio[u]rs, but also ... a lens through which actors evaluate their own options" (Meger, 2015, p. 418; Burt, 1982). In other words, whilst the institutions perpetuate gender stereotypes via tasks assignments and organizational structures, individuals themselves - both male and female - have internalized and thus subconsciously carried on the gender stereotypes (Meger, 2015, p. 419). Both anecdotal observations and empirical studies have demonstrated these impacts of gender stereotypes. Belligerent groups are reluctant to recruit women for combating roles "except in the most dire emergencies" due to the suspicion of their abilities to kill (Goldstein, 2001, p. 127). In interviews recalling conflict-time experience, women have commented on their own roles as less valuable and less contributory than those of the men, sometimes even shameful of their work, although they perform life-saving tasks (Roche, 2012).

Associating masculinity with conflicts and extolling the usefulness of masculine traits, the influence of gender stereotypes spread from conflict-time into everyday life, influencing social norms, cultural practices, and organizational behaviours. As a result, "prevailing gender stereotypes" assign men with higher values, more powerful positions, and better access to key resources (Goldstein, 2001), while linking women, their skills, 
and their work with lower values (Peterson, 2003, p. 62). Apparently, gender stereotypes have influenced the roles and values assignment among participants of conflict groups. Recalling that the economic development strategy (EDS) invests in these participants' economic well-being in hope to exchange for peace, one begs to question: should such investments follow the gendered value assignments or correct them? Soon, Chapter 6 and 7 will reveal how gender stereotypes hinder the effectiveness of the EDS-related policies.

\subsubsection{Exploitation of Women during Conflicts}

Affected by the gender stereotypes, most cultures and societies construct social reproduction as a female duty (Turshen, 2016), and "women are everywhere assigned primary responsibility for social reproduction" (Peterson, 2003, p. 63). Built upon the sexual biological differences, common narratives have constructed reproduction as "natural" work that women are born to know and thus can complete with no difficulties (Turshen, 2016, p. 9; Riley, 2008). Consequently, society deems women's contribution to social reproduction as "economically irrelevant" and "unskilled" (Peterson, 2006, p. 501).

Taken for granted, women's social reproductive labour is more than often subject to exploitation. During conflicts, society and culture push women away from the frontline and into the background of conflicts, in order to ensure their fulfilment of social reproduction (Lahai, 2010; Goldstein, 2001; Turshen, 2016). Since the conflict organizations deploy women at these posts out of exploitative reasons, women at these posts are rarely given due recognition, despite the social reproductive tasks are not only key to the survival and victory of the belligerent groups during conflict times, but also 
indispensable to the continuance and prosperity of the ethnicity and society in general (Turshen, 2016, p. 115).

Undervaluing women's role is a systematic problem not unique to conflict times, but common "across cultures and generations" (Riley, 2008). Whilst everyday narratives devalue women's effort in reproductive work, conflict narratives downplay women's role in the conflict organizations. Countless conflict documentations, whether oral and written, describe women in the conflict organizations providing support to the combatants as "camp followers" (Goldstein, 2001; Enloe, 2000). Enloe (2000, p. 37) argues this syntax primes one to perceive women as "dependent on [and] tag[ging] long" men. Such narratives downgrade women as men's subordinates, construct women's image as something lesser than that of men's, and thereby justify the men's exploitation of women's labour and the patriarchal organizations' neglect of women's contribution.

The exploitation of women's social reproduction also exposes women to heightened risks of violence. Conflict-time violence targeting non-combatant women is a common tactic that serves multiple purposes for belligerent groups (Chinkin \& Kaldor, 2013). Firstly, as discussed, society perceives women to be the key to reproduction. Applied to conflicts, such perception leads belligerent groups to see women as the key to reproduction of the rivalry group (Chinkin \& Kaldor, 2013, p. 172). Violating women's bodily and reproductive security thus disrupts the continuance and survival of the rivalry community. In ethnic conflicts, violating women also contaminates the purity of ethnicity, and cleanses the ethnicity of the enemy (Jaleel, 2013). The constructed images "of women as biological and symbolic reproducers of ethnic groups and nations [give 
rise to] gendered hatred that promotes rape as a weapon to dilute the nations of enemies." (Abramson, 2012, pp. 1070-1071)

Gender-based violence in conflict also provides belligerent groups with economic interests. Termed "extractive sexual violence," belligerent groups acquiesce and even encourage their combatants to transgress women in order to "extract wealth or to maintain unequal economic relationships" (Kirby, 2013, p. 808). Given the social stigmatization, women often find them difficult to return to the ethnic and local community to which they used to belong and had to follow their transgressors. In this way, transgressing women allow belligerent groups to gain free labour (Turshen, 2016, p.

104) In some cases, this also allows belligerent groups to traffic young women and increases income for the conflict organization (Jackson, 2003)

Plus, sexual violence is a tool of boosting combatants' morale. Gender stereotypes link women with the image of a "normal life" (Thapar, 1993, p. 88). Violation of women resembles and symbolizes the disruption of a peaceful time. Such resemblance instigates, justifies, and encourages men's aggression and killings (Goldstein, 2001). Additionally, conducting aggression reinforces masculinity: a constructed, stereotypical gender image associating men, aggression, and their competence in combats (Chinkin \& Kaldor, 2013, p. 177) .

\subsubsection{Gender Stereotypes and Exploitation in The SoS Conflicts}

The gender stereotypes and its impacts on women in SoS conflicts are analogous with those in general conflicts. Intentional or not, the adoption and continuous usage of 
the 1980s-coined term Sons of the Soil "[label] a conflict as involving 'sons' who protect the 'soil' -or the aptly name 'mother' land" (Côte \& Huang, 2017). As such, the extant SoS conflicts literature primes the accentuation of men's combating role and the feminization of the protectees.

Now that conflict and gender literature have debunked the gender roles in general conflicts, it is crucial to discern whether SoS is an exception. Although often started by male members attacking those of another ethnicity (Fearon \& Laitin, 2011), to say that females - an integral part of the interethnic, migration-based conflicts - are completely absent from the SoS conflicts is counter-intuitive. Empirical studies and anecdotal evidence have proven that women do participate meaningfully in certain SoS cases, and supportive cases are observed around the world. In the deep south of Thailand, 30\% of the armed conflict group are female (Klein, et al., 2010). Similarly, in the Liberation Tigers of Tamil Eelam (LTTE), female combatants represent 30-40\% of all combatants (Henshaw, 2017). Meanwhile, the Black Widow, a suicide bomber group heralding Chechen independence only recruits women (Kurtz \& Bartles , 2007).

Still, SoS conflicts are not immune to the impacts of gender stereotypes. In general conflicts, women's biological characteristics impose on them the perceived duties of social reproduction, the exploitation of which leads to the neglect of women's contribution to conflict organizations. For the same reason, in SoS conflicts, despite women's high and meaningful participation in SoS conflicts illustrated above, their noncombating work are taken for granted and thus underrated in the documentation of SoS conflicts. (Côté \& Huang, 2017). 
Unfortunately, for women on the combating posts, their presence in SoS conflicts is not a result from the falsification of the gender stereotypes, but rather, a different form of biases against women and exploitation of their reproductive capacity. Besides the perceived incapability of combating, the imposed social reproductive duties construct women's motherly image: they are weak, peaceful, and nurturing (Chinkin \& Kaldor, 2013; Goldstein, 2001). Thus, admitting women to combating roles can effectively "shame" and incentivise men to fight harder and better (Bloom, 2007, p. 99). Women's perceived peacefulness is useful in avoiding monitoring and security checks, allowing for higher chances not only in the transportation of weapons and equipment, but also in suicide bombing. Moreover, due to their motherly image, female perpetrators receive "eight times the media coverage" than male perpetrators (Bloom, 2007, p. 100). Suicide attacks by the LTTE and the Black Widow are cases in point that demonstrate how SoS conflict organizations tactically recruit female participants to exploit their social reproductive duties and accordingly constructed images.

In general cases, gender has a strong correlation with power and resource distribution; this holds true in SoS conflicts. To recap, amongst the core of SoS conflicts is the contestation of land, its resources, and the interests generated thereby. Since the masculinization of conflicts allows men of better resources and authority, predictably, men in SoS conflicts enjoy better access to land and its associated benefits.

Indeed, comparing United Nation's Gender and Land Rights Database (Food and Agriculture Organization of the United Nations, 2018) and Fearon and Laitin's SoS conflicts data (2011), one finds that the states and regions troubled by the SoS conflicts 
have significantly lower gender equality in agriculture holding rights than states exempted from SoS conflicts. Agriculture holding rights is an indicator useful in reflecting and comparing access to socio-economic resources across countries. A common parameter in agriculture census, agriculture holding rights shows who "makes the major decisions regarding resource use and exercises management control over the agricultural holding" (Food and Agriculture Organization of the United Nations, 2018). In other words, a person with agriculture holding rights has authority to decide over land usage and access to the profits. In the case of SoS conflicts, surveying the gender ratio of the agricultural holding rights helps show whether men or women have lopsided access to the land, its resources, and its profits, which are key to the contestation leading to the conflicts.

As predicted, SoS cases display rather gender inequality in land access. In most South and East Asian countries, where the SoS conflicts are most frequent (Fearon \& Laitin, 2011), in general around $8 \%$ of females have access to land and its profits. On the contrary, in most Latin American and Caribbean countries, where the SoS conflicts have not occurred to date, in general around $20 \%$ of females have such access (Food and Agriculture Organization of the United Nations, 2018).

An observation of customary and cultural practices further illustrates the gender inequality in land access in Southeast Asia. Women often hinge their economic interests on either their maternal family, which is run by a male head of household, or their husbands. Often, women are no longer considered as member of the family if they are married, and thus lose their land rights. Moreover, they are pressured to "renounce to 
their statutory rights in favour of male family members due to the economic and social dependence on their kin" (Food and Agriculture Organization of the United Nations, 2018).

This pattern also holds true in Sub-Sahara Africa, another region where Fearon and Laitin (Fearon \& Laitin, 2011) have coded most of the "Sons of the Soil" conflict cases. In Sub-Sahara African societies, restrictions are in place to bar women from inheriting land and property (Mooney, 2004). Comparable with the situation in Asia, women in Sub-Sahara Africa find themselves "ultimately dependent on a relationship with a man, whether with him or his family, to have access to land" (Bryant-Tarpeh, 2012, p. 16). That is to say, in households that rely on agricultural earnings, women do not have significant access to the land and its profits.

Not only in the aspect of land rights do women have a lower hand in access to resources and authority, and thereby economic well-being, but also in employment opportunities. Statistics show that women tend to follow their family when migrating, which decreases their options in employment (Hamid, 2010). In other words, if their families migrate to seek work and income other than in the agricultural sector, women still have limited power to make decision for their own economic well-being. Understandably, since the goal of SoS conflicts is for the rivalry group to re-gain control over contested land, its resources, and its interests, women who do not enjoy as much access and benefits from the conflict are less prone to participate in the clashes. As Fearon and Laitin observe, SoS conflicts typically "begins with attacks between gangs of young 
men from each side" in reaction to violation and insults of the indigenous group (2011, p. 199)

Above observations on the exploitation and economic inequality that women suffer in SoS conflicts prompt one to question the gender aspect of the economic development strategy (EDS) in the Uyghur-Han cases. While the ethnic minority are suppressed by the majority (Potter, 2007, p. 241), women in ethnic minority group are facing double exploitation. Hence, considering that suppression elicits resistance, one should argue for the EDS to rectify the injustices that ethnic minority women encounter and thereby prevent their upheaval. However, there are also grounds to argue that EDS should leave the status quo be. Exploited, women lack meaningful access to the land and the interests incurred. Consequently, they are less likely to participate in the clashes, and thus enfeeble the conflict organizations' mobilizing capacity. As such, the gender aspect of the economic development strategy has manifested its significance. Intended or not, the influence of the EDS on gender economic inequality will have an impact on the Uyghur-Han conflicts. 


\section{Part II Case Studies}

\section{The Uyghur-Han Conflicts: Classic SoS Cases}

\subsection{Applying SoS to the Uyghur-Han Conflicts}

Attracting increasing scholarly and policy attention, the Uyghur-Han struggles are typical SoS conflicts. Fearon and Laitin (2011, p. 201) codes the Baren Township riots in 1980 as the first Xinjiang SoS case. Subsequently, Côte (2015), Côte and Mitchell (2017) observe, label, and examine more SoS cases in the XUAR. Conflicts chronicled in Table 2 are highly compatible with the dynamics of the SoS as summarized in Chapter 4 . In these conflicts, one observes ethnicity, indigeneity, and migration components as defined. The level of casualty and the state support of one side of the rivalry are in accordance with the definition of the SoS conflicts as well.

In detail, all the clashes are initiated by the national ethnic minority who is native to, and majority of, Xinjiang, the Uyghur, against the national ethnic majority, the Han, who migrates into the region. This pattern holds true not only on the provincial level, i.e. the XUAR as a whole, but also on the district level, i.e. in the counties and cities. The majority of the conflicts tabulated occur in Southern Xinjiang, "especially in the three districts of Aqsu, Kashgar and Hotan, [where] the Han are a clear minority" (Joniak-Lüthi, 2016, pp. 2191-2192). Comparatively, "in northern Xinjiang, [where]the Han are clearly in the majority," (Joniak-Lüthi, 2016, pp. 2191-2192) only 3 out of 52 conflict cases have occurred for the past four decades. Demographics of the counties in which these conflicts occur are highly compatible with other SoS conflicts in the XUAR: the Uyghur residents are the majority except for the one in Qorghas County (Statistics Bureau of Xinjiang 
Uyghur Autonomous Region, 2017). Except for pre-meditated, organized attacks in political capitals, these conflicts report fewer than 50 counts of deaths. As Chapter 2 has mentioned and Chapter 6 will continue demonstrating, the Han population flows into Xinjiang result largely from policy or state-backed campaigns.

The Uyghur-Han clashes display characteristics that are unique to SoS conflicts but uncommon in traditional ethnic conflicts. In these clashes, ethnicity does not play as decisive a role in determining conflict organization or hostile relationship as in traditional ethnic conflict. As discussed, SoS conflicts distinguish from traditional ethnic conflicts due to the crossing of the ethnic boundary. In the Uyghur-Han clashes, people of Han ethnicity do not necessarily stand against the people of Uyghur ethnicity. Many Han people who relocated to Xinjiang a long time ago or were born in the XUAR "self-identify as Xinjiangers (Xinjiangren), Locals (Bendide) and Genuine Xinjiang Locals (Lao Xinjiang)" (Joniak-Lüthi, 2016, p. 2192). These “Xinjiang Han[s]" and the Uyghur in Xinjiang identify and share the autonomous region as their true, primary homeland (Joniak-Lüthi, 2016, p. 2192). Regarding matters of their homeland, the "Xinjiang Han[s]" align with the Uyghur in Xinjiang more than with the new-coming Han in-migrants (Joniak-Lüthi, 2016, p. 2192; Cote, 2015). As such, ethnic identities do not dictate conflict organization. Individuals associate themselves with the conflict organizations based on the interplay of their ethnic and indigenous identities.

Neither do the discrepancies of ethnic identities alone predict an interethnic conflict from the Uyghur against another ethnic group. Besides the Han, there are 53 other ethnic minority groups cohabiting the Uyghur, and not all of them are aboriginal of the 
region (Executive Office of the People's Government of Xinjiang Uyghur Autonomous Region, n.d.); however, major interethnic clashes have rarely occurred between the Uyghur and ethnic groups other than the Han.

The Uyghur-Han conflicts also differ meaningfully from civil wars. An examination of the casualty counts proves why civil war studies are not compatible with the Uyghur-Han clashes. Like other SoS conflicts, the Uyghur-Han clashes generally have fatalities lower than the civil war definition thresholds. None of the clashes since the 1980s report a total death count of 1000 or more, and most of the cases have less than 100 deaths per year. Although the outliers, i.e. the Urumqi 7/5 and the Kunming attacks, do result in a death toll of over 100, at least one side of the belligerents shows less than the 100 deaths threshold, thus failing the civil war definitions.

There is a consensus among scholars that the principal grievances contributing to the Uyghur-Han clashes are the inequalities between the two groups on their political and socio-economic status (Ramachandran, 2017). Applying Stewart's (2008) concept of Horizontal Inequalities (HIs), Côté (2015) captures these inequalities and demonstrates how the HIs between the Han and the Uyghur predict the conflict severity of the interethnic clashes in Xinjiang. Chapter 2 reviews and demonstrates the unequal treatment and opportunities on income, employment, social status, and issues alike that HIs capture. 


\subsection{Applying FPE in the Uyghur-Han Conflicts}

Gender stereotypes and resulting inequalities observed in the Uyghur-Han clashes are comparable with the picture of general conflicts and SoS cases. In the Uyghur-Han conflicts, Uyghur women experience multi-level of oppressions. Within the state, they face dominance and unequal treatments from the majority. Within the household, they provide labour but are taken for granted and denied substantial profits. As Chapter 6 will discuss, when migrate to work on assembly line and light-industry factories, they undergo capitalist-style exploitation.

Uyghur women suffer both interethnic and gender economic inequalities. Whereas the male-female population ratio is 106.8 in the XUAR, the male-female employment ratio is 142.7 in 2015 (Statistics Bureau of Xinjiang Uyghur Autonomous Region, 2017, pp. 3-3, 3-18, 3-19). ${ }^{18}$ In other words, for every 100 women, there are approximately 107 men in Xinjiang. However, for every 100 women employed, there are approximately 143 men employed. Whilst local employment opportunity is unfair for women in the XUAR, local and Islamic cultures also hinder Uyghur women from migrating and seeking work outside of their home community (Li \& Pan, 2015).

Exacerbating the economic lower hand in employment opportunities is the gasping gender gap. Zang's study (2011) shows that while Uyghur individuals typically have lower income than their Han counterparts, Uyghur women has lower income than

${ }^{18} 2015$ is the latest year in which data is available. 
Uyghur men. When Han men earn on average 1362 RMB per month and Han women 886.4 RMB, Uyghur men earn on average $1198 \mathrm{RMB}$ and Uyghur women 619.7 RMB (Zang, 2011, p. 153). Confronted by such double jeopardy, Uyghur women suffer inequality attributed to both ethnic and gender identities.

Like in ethnic and civil wars, gender stereotypes affect the organization and development of the SoS conflicts between the Uyghur and the Han. Built upon the perceived reproductive duties, women's "symbolic images have offered a powerful and malleable form to define the [Uyghur] collectivity" (Abramson, 2012, p. 1071). Advocacies appealing to nationalistic and separatist emotions call for protection of Uyghur motherland. Leaders of these separatism movements are aptly branded as "mother of the Uyghur" (Abramson, 2012, pp. 1071-1072).And, as Chapter 6 will discuss, due to biological characteristics and gender stereotypes, the Uyghur community see Uyghur women as the producers of the next Uyghur generation. Consequently, the virginity of Uyghur women turns into the key to the reproduction of ethnically pure Uyghur.

Since 2007, ethnic minority migrant workers departing the XUAR for other parts of China has been on rise. From 2007 to 2012, the out-flowing population grew from 1,500,000 to 2,580,000 (Li \& Pan, 2015). Around the same time, the number of female migrant workers exceeds that of the male's. Yet, despite the scale of migratory movement both by ethnicity and gender, extant literature still overly focuses on men (Liang \& Chen, 2004). Current media, academic, and policy continues depicting the Uyghur-Han conflicts - like other SoS cases - as violence by men against men (Chinkin \& Kaldor, 
2013). For instance, a survey of past reports indicate that men are the majority of both the perpetrators and the victims (CCTV News, 2013; Phoenix News, 2013; Volodzko, 2015; People's Daily International, 2009). Public security policies also single out men as high risk factors (People's Daily, 2017; Rui, 2014; Jiang \& Fang, 2014). However, as Chapter 4 has demonstrated, not only are women meaningfully present in the Uyghur-Han conflicts, with their exploitation and their reaction thereto, they also interfere with the efficiency of the economic development strategy. In this case, neglecting women's role in the UyghurHan conflicts will have consequential impacts of the comprehension, intervention, and prevention of the clashes. 


\section{Qualitative Analysis: EDS, Gendered Policy Outcomes, and Conflicts}

\subsection{Logic and Problems of the EDS}

Conflict scholars have proposed a correlation between economic well-being and conflict outbreaks. Termed the "conflict-poverty nexus," this correlation suggests that the poorer a state is, the more conflict-prone it will be. Using GDP per capita as a measurement, Fearon and Laitin (2003) and by Collier and Hoeffler (1998) both find an inverse relation between the GDP per capita and the count of conflicts. Conversely, as the outbreak of a conflict hinders economic growth, it contributes to poverty and thus continues this malicious cycle (Chandler , 2015).

The conflict-poverty nexus is enormously relevant to SoS conflicts. Empirical studies based on cross-country analyses (Collier \& Hoeffler, 2004; Fearon \& Laitin, 2003; Miguel, et al., 2004) corroborate that economic performance is a major contributor to intrastate and ethnic conflicts. Corresponding with Stewart's theory on the HIs, this empirical observation is especially outstanding if the economic disparity between the two involved groups is significant (Østby, 2008; Cederman, et al., 2011). In countries and regions "where much of the population is dependent upon the environment [and] natural resources for their livelihoods," such pattern is even more prominent. On these occasions, the contestation over natural resources is more severe due to economic dependence. The dependence on environmental and natural resources also renders the population more vulnerable to conflicts than in other cases. As a conflict disrupts the productive activities and capabilities of a community, who has limited income sources other than the land and 
its resources, damage to the environment and nature take a long time to recover, the people are often stuck in poverty after the conflict (Clionadh, 2011).

By definition, SoS conflicts are contestations of land, its resources and profits derived from these resources, it is therefore manifest how the conflict-poverty nexus is applicable in SoS cases. In SoS conflicts, the lack of economic development is tied with the deprivation of land and productive means (Do \& Iyer, 2009, p. 3) Therefore, it should not be a surprise that the prominence of the conflict-poverty nexus corresponds with that of SoS cases. In Africa and Asia, the two continents where SoS conflicts frequent (Fearon \& Laitin, 2011), the high conflict rates and low economic growth relationship is notable (Blomberg, et al., 2006).

Adopting the conflict-poverty nexus, many international organizations (IOs) and local governments have enacted policies and programs targeting poverty not only as an end in itself, but also as a means to reduce conflicts. Additionally, the World Bank works around a development-humanitarian-crisis nexus. Understanding that "development is the best resilience" to conflicts and its aftermath, the World Bank has been investing in impoverished regions. "Tak[ing] guns and giv[ing] jobs," the World Bank gradually decrease conflict-related humanitarian crisis. ${ }^{19}$ Championing a similar logic, the United Nations (2018) calls for investment of local development in its Sustainable Development

${ }^{19}$ Excerpt from conversation with CEO of the World Bank Group, Kristalina Georgieva, at Lester B Pearson Building, Ottawa, Canada on September 28, 2017. 
Goals. Recognising the limited function of fragile states, the Organization of Economic Cooperation and Development (OECD) (2011) recommends international cooperation in reducing poverty and thereby preventing "destabili[zation] of entire regions and [the] global repercussions." Likewise, the African Union (2005) guides its member states on resolving poverty, naming it a major hindrance to peace.

However, emerging literature has started to reveal the problems of such development-for-peace blueprints. Leaving the patriarchal family framework unchallenged, many of the development policies implemented by the World Bank in the "Third World" turn out to continue allowing men's exploitation of women (Bedford, 2009). Micro-financing programs, one of the development policies that the IOs favour, can bind women to their oppressors and contributes to radicalized violence since the programs leave traditional structural violence untouched (Rankin, 2001; Hossein, 2016). In addition, some of the World Bank programs designed to alleviate poverty do not find it problematic to operate on the assumption "that women deserve to be paid less than men and that the low-wage jobs being created in many developing countries (such as service work, call centers, or sweat shops) should be 'women's work'" (Decoteau, 2011, p. 566).

These internationally observed outcomes are relevant to the Chinese version of EDS in the Uyghur-Han conflicts. In sections to follow, one will see how the EDS-related policies, although indeed improve the economic well-being of the Uyghur and the XUAR, leave the patriarchal social structure unchallenged. Women are still exploited one way or another. When the policy-induced changes disrupt the existing order of community and 
the gender roles therein, they increase the Horizontal Inequalities (HIs) and give rise to conflicts. 


\subsection{A Survey of EDS-related Policies and Consequences in the XUAR}

\subsubsection{The Xinjiang Production and Construction Corps}

After Xinjiang's "peaceful liberation" (Clarke, 2008, pp. 275-276), the People's Liberation Army (PLA) stayed put in Xinjiang. While there, they disarmed and turned their forces and resources to provide for their own needs and help with local construction and production. In 1954, the central government instructed the PLA troops in Xinjiang to convert into PLA's "Xinjiang Military District Production and Construction Corps" (bingtuan in Chinese for short) that no longer fell under the control of national defence. From then until the mid-1970s, the Corps focused on protecting China's border safety and conducting some agricultural work. (The State Council Information Office of the People's Republic of China, 2014).

In 1981, the central government revived bingtuan from the disruption caused by the Cultural Revolution and turned it into "Xinjiang Production and Construction Corps" (XPCC) (The State Council Information Office of the People's Republic of China, 2014). This drop of the military component is more than nominal. Beginning in the 1980s, the XPCC shifted towards economic development as its key objective. Later in 1998, the central government issued three policies that collectively assured the status of the XPCC as a corporation (Cliff, 2009, pp. 86-87). Incorporated, the XPCC is independent of the XUAR government. It answers directly to, and receives funding from, the central government (The State Council Information Office of the People's Republic of China, 
2014). Given that it is the XPCC - the de-militarised ${ }^{20}$ and incorporated form of bingtuan since the late 1980s and the beginning of the 1990s-that focuses of economic development, this chapter analyses policies and consequences of corresponding eras.

Among XPCC's work, urbanization, industrialization, and agricultural modernization of Xinjiang are the pillars of development policy (The State Council Information Office of the People's Republic of China, 2014). The results of this work are noteworthy. Over time, the XPCC "has become a main driving force for Xinjiang's agriculture. It has made irrigation works in more than ten main rivers and canals, constructed 3,200 irrigation projects, and cultivated 1.07 million acres of land" (Zhu \& Blachford, 2016, p. 37). The XPCC is also a main driver of Xinjiang's economic growth. It contributes significantly to the region's GDP, accounting for $50 \%$ of Xinjiang's economic activities in the secondary industry and more than $30 \%$ of the tertiary industry (The State Council Information Office of the People's Republic of China, 2014).

Endorsed by the central government and bolstered by its noteworthy impacts, the XPCC enjoys great power and influence, with which it is tilting the political, economic, and demographic balance in favour of the Han people in Xinjiang. As such, some literature has pointed to the XPCC as "the chief vehicle of the [internal] colonization" of Xinjiang (Becquelin, 2004). Beijing's policies have cleared the way for the XPCC to claim

${ }^{20}$ De-militarised in comparison with its previous form. However, the XPCC is still a quasi-military organization in scholarship and policy literature. 
land and establish its own counties and cities in Xinjiang. Up to 2015, the XPCC has occupied $4.24 \%$ of Xinjiang's territory, totalling 706,000 square kilometres. ${ }^{21}$ Around $17 \%$ of this land is cultivated and arable. Although the acreage of arable land seems rather small (Becquelin, 2000), the XPCC controls the viability of most of it through control[ling] the water supply" (Cliff, 2009, p. 92). In addition, the XPCC runs 14 cities and governs 27,656,000 individuals within the autonomous region (Xinjiang Production and Construction Corps, 2018). Towns and cities that have experienced economic growth are almost all associated with the XPCC, and generally, "the closer the association, the more spectacular the growth" (Cliff, 2009, p. 91).

Backed by Beijing, since the 1990s, the XPCC has continued to expand its power and influence in the XUAR by out-reaching to marginalized areas, providing construction of infrastructure, and developing new city centres, all of which call for an increased amount of labour. In addition, around this time, in mainland China "peasants and workers feel that their livelihood is threatened by the restructuring associated with the market economy" (Cliff, 2009, p. 89). Consequently, starting in the 1990s, migration has poured from mainland China into the XUAR.

Given the abundance of natural resources and natural resource-reliant jobs, most migrants favour the Southern part of Xinjiang as their destination, resulting in a rapid increase of total population and Han population in the area (Ren, et al., 1998; Joniak-Lüthi,

${ }^{21}$ Which is equivalent to $70 \%$ of Ontario's land. 
2016). Throughout the 1990s, the majority of the migrants are of Han ethnicity (Ren, et al., 1998, p. 39). As a result, Han population grow from 2.71 million to 6.74 million, which almost double from 1981 to 1999 (Statistics Bureau of Xinjiang Uyghur Autonomous Region, 2017) $)^{22}$.

Among the in-coming migrants in this era, male migrants constantly outnumber female by double the amount (Ren, et al., 1998, p. 39). Understandably, the male/female population ratio of the XUAR is on steady rise throughout 1990s (Statistics Bureau of Xinjiang Uyghur Autonomous Region, 2017). The masculinization of in-coming migrants is explicable from two aspects. To begin with, most migrants turn to Xinjiang for job prospective due to the perceived threats under China's economic reform. Scholarships have demonstrated how the reform processes "put burden unfairly onto women," since they more often than their male counterparts "pick up new unpaid caring tasks in the household" (Berik, et al., 2007, pp. 4-5). Restricted to the household, women have fewer opportunities to travel away for work as men do. Further, in this decade the XPCC dedicates to construction of infrastructure, a job market in which women are perceived to be of less use and thus less competitive. Evident in the population statistics, the XPCC's expansion has tilted the demographics in Xinjiang both in terms of ethnicity and gender.

22 Calculation included the population in the XPCC. 1981 is selected as the benchmark year since it is the earliest year in which relevant statistics are available. 1999 is selected as the comparison year since 2000 is the year marking the Great Western Region Development (GWRD) and thus is the benchmark year for measuring the impact of the WRD. 
The arrival of large number of male-dominant, Han migrants has not been wellreceived. In the eyes of the Xinjiang locals - be they Uyghur or Han by ethnicity - these new-comers have increased the crime rate and are thus a "danger to society (weihai shehui)" (Ren, et al., 1998, pp. 38-39). Moreover, since most of these migrants are Han, the local Uyghur view the population movement "as a way of diluting local culture and ensuring Beijing's control" of Xinjiang (Dillon, 2003). At this time, the gender balance of the Xinjiang population has just begun to tilt, with its impacts growing and lurking.

\subsubsection{The Great Western Region Development}

In 1999, during the 9th People's Congress meetings, the then Chinese President Jiang Zemin proposed the strategic notion of the Great Western Region Development (西 部大开发, xibu da kaifa) (Zeng, 2010). At the time, resulting from the Open Up and Reform campaign, eastern China had taken a frog-leap in its economic progress. Meanwhile, although the West has also experienced growth, such growth is not as fast as that of the East. Consequently, the economy of the West has fallen significantly behind that of the national and eastern economies. Based on a calculation taking 1998 as the base year, the West would need thirty years to catch up with the East in terms of their economic wellbeing. Furthering this challenge is the unrealistic requirement that this goal would only realize if the West grew at a faster rate than the rest of the country throughout this 30 year period (Zhou, 2003).

Out of concern that the widening economic gap between eastern and western China can lead to unrest, Jiang and his government gradually developed the GWRD from 
a prototypical idea into a solid action plan. Attached with great strategic value, the initiative eventually became a core guiding policy in the 2000s (Zeng, 2010; Chinese Communist Party 15th Central Committee, 1999). In short, the GWRD has encouraged eastern China to partner up with their less developed, western counterparts, providing the latter guidance, information, capital investment, human capital, and advanced technologies. This vision is, with the help of the East, that the West will develop industries that suit its political, economic, and geographic characteristics and catch up with the national economic performance (Chinese Communist Party 15th Central Committee, 1999).

In detail, derived from the GWRD initiative are many auxiliary projects, among which construction of infrastructures in the West-i.e. water supply, transportation, communication, and electricity, and urban development - is the key. Additionally, there are massive projects linking the resources of the West and the wealth of the East ${ }^{23}$. Directed and funded by the central government, these projects serve multiple purposes and benefits. Firstly, they help the West with attracting investment and thereby pursuing development, relying on its abundant natural resources. Secondly, they provide the East with a solution to the lack of energy, which is hindering their daily life and industrial development. Thirdly, the development of the West will enhance China's domestic needs,

23 西电东送(xidian dongsong) and 西气东输(xiqi dongshu): these two projects literally mean sending electricity in the western region to the eastern region, and sending the gas in the western region to the eastern region. 
which in turns assist the continuing economic growth of the East and the entire country (9th National People's Congress, 2001; Zeng, 2010).

After the implementation of the GWRD initiative, entrepreneurial business and individuals from China and abroad poured into the West. Among them, those from eastern China took up the most opportunities. Within the first two year, the East and Xinjiang had completed contracts that were worth more than 200 billion RMB (The Ministry of Science and Techonology of the People's Republic of China, 2002). Within the first four years of the GWRD implementation, over 30,000 companies from eastern China invested and started operating in the West (Zeng, 2010).

The massive in-migration following the GWRD drastically changes the demographics of the XUAR. Recalling that eastern China is populated by Han Chinese, one may have predicted that the influx of eastern Chinese companies and personnel has a bearing on the ethnic component of Xinjiang's population. Before the year 2000, the Uyghur-Han population ratio in Xinjiang remains steady at approximately $1.2^{24}$, which means for every 12 Uyghur individuals there are 10 Han among the Uyghur population,

24 The Uyghur-Han population ratio does not drop below 1 prior to the GWRD, except for in late 1996 till early 1997, the ratio drops to 0.9. However, this is explicable since in 1996 and early 1997 several riots occur, prompting Beijing to send in Han-dominant troops to Xinjiang. See Table 2 for details of the incidents, and Chapter 7 for method and usage of population statistics. 
with the XPCC population taken into account ${ }^{25}$. The year of 2001 reports a notable change: the Uyghur-Han population ratio ${ }^{26}$ drops below 1 . That is to say, taking the XPCC into account, for every 8 Uyghur there are 10 Han in Xinjiang's population. This number continues decreasing from 2001 to 2005, which coincides with the first phase of the GWRD ( (Statistics Bureau of Xinjiang Uyghur Autonomous Region, 2017; National Bureau of Statistics of the People's Republic of China, 2017). The Uyghur - the dominant ethnic group - are de facto ${ }^{27}$ outnumbered in their autonomous region.

The GWRD tilted the balance in favour of the Han population in Xinjiang not only in terms of demographics but also the economic benefits. Under the GWRD, the northern part of Xinjiang - which the Han populates - experienced rapid economic growth that is "exemplary and leading (shifan he daitou)" of the GWRD (The Ministry of Science and Techonology of the People's Republic of China, 2002). In contrast, southern Xinjiang where most of the Uyghur population in Xinjiang is concentrated - are significantly less developed. The economic gap between the northern and southern Xinjiang appears under the GWRD and remains today: the south has less than half of the economic activities than the north (Zhang, 2012). Correspondingly, some scholars have argued that

${ }^{25}$ Census and population surveys of the XUAR do not normally reflect the situation of the XPCC-affiliated units. This number is calculated based on the census and survey results both from the XUAR and the XPCC.

${ }^{26}$ With XPCC affiliated units counted.

27 Statistically, when excluded the XPCC units and their population, the Uyghur population still trumps that of the Han. This is also the common practice in census and survey in the XUAR and China. 
the GWRD has led to "the economic alienation of the local Uyghur at whose cost the immigrant Han have benefited" (Ramachandran, 2017, p. 275).

The increase of male/female population ratio carried on from under the XPCC into the GWRD era. Similar with the XPCC, the GWRD centres on construction of infrastructure, an area where jobs are more open to men than to women due to biological differences and gender stereotypes. Moreover, the leading projects under the GWRD mostly revolve around the heavy-duty industries and natural resources excavation (Zhang, 2012). As the jobs in these areas favours male labour more than females one, naturally, more male migrants flow into and are able to stay in the XUAR. The increment of male population is most astonishing in 2001: the year immediately after the announcement and the implementation of the GWRD, when the morale is highest (Zeng, 2010). Within one year, the male-female population ratio in Xinjiang increased from 105.4 to 107.5, which far exceeds the national rate (National Bureau of Statistics of People's Republic of China, 2016; National Bureau of Statistics of the People's Republic of China, 2017; Statistics Bureau of Xinjiang Uyghur Autonomous Region, 2017).

\subsubsection{The Labour Export Program}

The comparatively backwards economy challenges the XUAR not only with low level economic activities but also rampant unemployment problems. As a response, around 2004, the XUAR government began organizing unemployed labour to move within the XUAR for seasonal work. Taken up at the national level, this initiative later became the now known Labour Export Program (LEP) (Wang, 2009). The LEP continue 
to organize surplus labour in Xinjiang and send them to coastal Chinese provinces. Usually, the migrant labour works in light industry and labour intensive factories (Zhang \& McGhee, 2014). In recent years, the XUAR government and the central government have also funded certain training programs for the surplus labour in Xinjiang, preparing them the skills to better suit the needs in mainland Chinese factories, and the language and cultural training to better integrate with the host community (Ministry of Human Resources and Social Security of the People's Republic of China, 2008; Department of Human Resources and Social Security of Xinjiang Uygur Autonomous Region, 2010; Department of Human Resources and Social Security of Xinjiang Uygur Autonomous Region, 2015; Ahinur, 2018).

The scale of population movement indicates that the LEP is a success. Uyghur residents in Xinjiang have gradually abandoned their "stick to the pastoral" mind-set and leave for work in the cities (Li \& Pan, 2015): from 2007 to 2012, the number of migrant workers leaving Xinjiang grew from 1.5 million to 2.58 million. Coincidentally, around the time of the LEP implementation, the male/female population ratio began dropping for six consecutive years (Statistics Bureau of Xinjiang Uyghur Autonomous Region, 2017; National Bureau of Statistics of the People's Republic of China, 2017). During 2004-2010, not only was the male/female ratio dropping but also staying below the national population gender ratio.

This phenomenon is worth probing given that in the 2000s, due to the influence of the XPCC and the GWRD, the male/female population ratio in Xinjiang increased and soared above the national standard. To say that the LEP - the policy that comes 
immediately before this notable change - is irrelevant would be counter-intuitive. Indeed, a closer look at the LEP reveals that the majority of the out-going migrants from the XUAR are female (Department of Publicity of CPC XUAR Commitee, 2007). Field trips and case studies in Kashgar - a key province exporting labour from the XUAR to coastal Chinese provinces - corroborate that Uyghur female migrant workers outnumber their male counterparts under the LEP (Ma , 2007).

Several factors can explain the feminization of the out-going migration under the LEP. Unlike Xinjiang, coastal provinces rely their economic well-being heavily on the tertiary industry instead of the primary and the secondary. The surplus labour from Xinjiang, however, generally lack the professional training or education to work in the high-end service industries like finance and IT. In the meantime, the language barrier limits their chances of working in simpler service positions, for instance, in retail or restaurants (Gao \& Zhu, 2013; Ma , 2007). As a result, most migrant labour exiting Xinijang ends up in labour intensive work in light industries, i.e. on the assembly line of a toy factory. On the receiving end, these factories seem to favour women over men. From the perspective of the employers, Uyghur women are "calm and obedient," whereas male Uyghur migrants are perceived to be rowdy and "turbulent" (Côté \& Huang, 2017; Gladney, 2004). In all, under the LEP, Uyghur women tend to be more popular for employment than Uyghur men.

Drastically decreasing the number and percentage of female Uyghur population, the LEP causes many criticisms and grievances from the Uyghur community towards the policy and the government. In Uyghur narratives, the LEP is a sugar-coated campaign to 
rid the backwards Uyghur traditions and ideologies (Congressional-Executive Commission on China, 2010). Some Uyghur reports depict the program as an exploitation of Uyghur women's labour as well as a coercive transfer (Abramson, 2012, p. 1080; Ma , 2007). There are also fears that Uyghur women who participate in the LEP “will become prostitutes or marry Han men" (Abramson, 2012, p. 1080). Even when the Uyghur women return to their home community from the LEP, their community do not necessarily accept them, since the Uyghur men are worried that "there's a chance [they] would not come back with [their] virginity" (Jacobs, 2009).

\subsubsection{The Rapid Spike Projects}

In addition to sending surplus labour away, the government also has tried to provide jobs locally in Xinjiang. Starting in 2014, the XUAR government has funded and assisted businesses to operate in impoverished areas within Xinjiang. Named Rapid Spike $e^{28}$, this initiative targets industrial projects that can develop quickly and introduce jobs while requiring rather small-scale governmental and financial support (National Development and Reform Commission of People's Republic of China, 2014). Facilitating this initiative, the XUAR government also funds employability skills training for Xinjiang

${ }^{28}$ A brief note on translation: The Ministry of Foreign Affairs has yet proposed an official translation of the initiative. In Chinese, the name of the industrial initiative literally means "Short, Cheap, Fast" (短平快). The author translates the term into Rapid Spike to proximate both the meaning and the connotation in the source language. 
residents so that they can better participate in the Rapid Strike Projects (Ministry of Human Resources and Social Security of the People's Republic of China, 2014).

The economic performance divergence within the XUAR prescribes that most of the Rapid Spike Projects (RSPs) take place in southern Xinjiang, the economically disadvantageous and Uyghur-populated area (National Development and Reform Commission of People's Republic of China, 2014). Given that the government prefers projects of low investment with high and fast returns ${ }^{29}$, unsurprisingly, most RSPs are light industry factories relocated from coastal Chinese provinces with low demands on labour skills and technologies. Consequently, after 2014, the map of southern Xinjiang began to be dotted by small, labour-intensive factories, for example, producing textiles, assembling electronics, and processing food. Having observed the trend and building upon the RSPs, the central government later guided and funded the textile industry in southern Xinjiang as a way of solving local unemployment and poverty (Han, 2017; General Office of the State Council of the People's Republic of China, 2015).

Whereas the heavy-duty nature of the XPCC and the GWRD signifies a job prospect favourable to Han men, the RSPs have demonstrated a lopsided employment pattern in favour of Uyghur women. On average, each year the RSPs add 30,000 jobs to Xinjiang, which are mostly - if not completely - taken by Uyghur women (Dong, et al.,

${ }^{29}$ Low investment in terms of government funding; high and fast returns in terms of contribution to jobs and local economic well-being. 
2015; Geng, 2018). In field trips and interviews at the RSP factories, one can hardly spot male workers. It is also not uncommon that certain workshops in these factories are comprised of only Uyghur women with a few Han women as supervisor or manager (Zhang, et al., 2015; Ministry of Human Resources and Social Security of the People's Republic of China, 2017). Participating in the RSPs, Uyghur women can make monthly earnings that outweigh the annual income of the entire family, and thus challenging the traditional Uyghur family value that it is women's duty to stay and obey the patriarchal household (Ding, 2017). 


\subsection{Linking Gendered Policy Outcomes, HIs, and Conflicts}

The above survey of the EDS-related policies in Xinjiang demonstrates that the policy impacts tilt the demographic balance, not only in terms of the ethnic component of the population, but also in the gender aspect. Under the Xinjiang Production and Construction Corporation(XPCC) and the Great West Region Development (GWRD), male-dominant Han migrants flush into Xinjiang. Incentivising these influxes of inmigrations to Xinjiang is the job prospects associated with the government developmental initiatives. From the XPCC to the GWRD, the 1980s till the early 2000s is a phase when the government make capital investment to boost the local economy. Afterwards, the Labour Export Program (LEP) and the Rapid Strike Projects (RSPs) mark the new phase of China's EDS in Xinjiang. Starting in mid 2000s, the focus of EDS shifts from attracting capital to solving local unemployment problem. This phase has witnessed a female-dominated outflow of Uyghur migrants from Xinjiang to coastal China as well as increased employment opportunities for Uyghur women.

These gendered employment and migratory patterns are reflections of widespread gender segregation in occupation. Influenced by gender stereotypes, employers prefer men in heavy duty work and women in labour-intensive work, since the former are considered tough and the latter considered docile. Internalized, men and women may consciously or subconsciously make occupational choices conforming to these popular gender biases as well (Radford, 2002). Therefore, under the XPCC and the GWRD where construction work is the pillar, men benefit more from the EDS. In contrast, when the LEP and RSPs introduce mostly labour-intensive jobs - commonly perceived as feminized 
work - women are the beneficiaries and men are "marginalized" (Peterson, 2003, p. 64). As a result, before the mid-2000s, the XUAR experiences an influx of male-dominant Han migrant workers, and, in contrast, since the mid-2000s, an out-pour of female-dominant Uyghur migrants. Among those who stay in Xinjiang, at present, Han people enjoy the advantages over Uyghur in getting employed, both in terms of opportunities and pay (Zang, 2012). Whereas among the Uyghur community, women are advantaged over men, leaving the Uyghur men worse off.

These gendered policy outcomes from the EDS aggravate the horizontal inequalities (HIs) between the Uyghur and the Han, and thus contribute to interethnic conflicts. The influx of Han men has become perceived as a menace for the locals in two aspects. Firstly, as Han men compete against the locals for their jobs - and most of the time, better jobs - they are a threat for the locals' economic opportunity. Secondly, when unemployed but refusing to leave the host community, these Han migrants turn into perceived risk factors to local security in the eyes local government and residents (Ren, et al., 1998, p. 39). This logic applies equally to Uyghur men: when they turn jobless, society treats them as threats to public safety as well. Therefore, when a large number of unemployed men are present - whether Han or Uyghur, be it the result of the XPCC, GWRD, or RSPs - the local community feels threatened for their economic and personal security. Consequently, the Xinjiang locals reacts adversely to the EDS. This logic helps explain why in the Uyghur-Han conflicts the ethnic identities are not the determining factor of conflict organization and mobilization. Essentially, it is the locals - the "indigenous" Uyghur and Han population - reacting against the in-coming Han 
population, who are often seen as a symbol of the attempt to dilute local culture and practices (Dillon, 2003).

Whereas the noteworthy presence of in-migrating Han men endangers the locals' perception of safety, the outflow of Uyghur women jeopardises the sense of survival of their ethnicity, identity, and community. When Uyghur women leave their community to pursue employment in other parts of China, Uyghur men worry that they will not return home or will not return with their "purity" (Jacobs, 2009), without which they cannot reproduce the next generation of Uyghur society. Subsequently, the fear emerges that the EDS is obstructing the generational reproduction of the Uyghur community. Consequently, there is "little wonder that the labour programs and anxieties about the chastity of women coalesced to form a spark that prompted the protests by Uyghur in Urumqi on July 5, 2009"' (Abramson, 2012, p. 1083).

In addition, women working - especially working away from home and working while men are unemployed - is a daring challenge to the traditional patriarchal values and order of the Uyghur society (Ding, 2017; Zang, 2008; Zang, 2012; Zang, 2010). Therefore, it is explicit that Uyghur men tend not to support the labour programs empowering women, viewing them as a threat to their interest under the patriarchal framework. This observation also helps explain the development of the July 5th riot in Urumqi. Under the labour programs, Uyghur men are marginalized at home and in the host community: back in Xinjiang, they lack employment opportunities in comparison with the women; in coastal Chinese workplaces, they face discrimination and barriers to integration. The allegation of Uyghur raping Han women, and the subsequent call to 
expel Uyghur workers fuel Uyghur men's "collective sense of humiliation" (Murshed, 2005, p. 78). Compelled by all these negative emotions, Uyghur men turn to violence as a way to vent their resent to Han ruling (People's Daily International, 2009; The Economist, 2009).

Eventually, consequent to the EDS-related policies, the gendered migratory and employment patterns fit well into the popular gender biases and widen the gaps between the Uyghur and the Han. With the HIs already in place, EDS presents to the Uyghur increased challenges from the Han for their economic well-being, communal safety, ethnic purity, and identity continuance. In this way, the gendered policy outcomes of the EDS enhance the tension between the Uyghur and Han.

Hitherto, qualitative analysis has partially confirmed the argument that this study sets out to prove: that the EDS in Xinjiang results in gendered migratory and employment patterns. It also suggests that these gendered patterns, when intertwined with existing gender biases, can explain the unrests in Xinjiang. The next chapter conducts an empirical analysis to complement the qualitative findings. As such, it tests whether the gendered migratory and employment patterns contribute to the Uyghur-Han conflicts, and if so, how. 


\section{Empirical Analysis: Gendered Outcomes of the EDS and The Uyghur-Han Conflicts}

\subsection{Research Design}

\subsubsection{Stages of Testing and Rationale}

To test the hypothesized correlation between gendered migratory and employment patterns and the Uyghur-Han conflicts, the study plans two stages of correlation testing using simple OLS model. Stage I tests the correlation, while Stage II tests the validity should the first stage returns confident results.

In the Stage I, this study begins with testing whether the frequency of conflicts correlates with the ethnic construction of the XUAR population. The intention of this step is to check whether, as the concept of SoS prescribes, the ethnic component is indeed at play in the Uyghur-Han conflict mechanisms. Similarly, the second step tests whether ethnic attachment to land - in other words, one's perceived right to the land that the ethnic group has dwelled on, an indispensable component of SoS conflict - is at play in the Uyghur-Han cases. Should the Uyghur-Han conflicts suit the SoS conflicts definition and developmental patterns as discussed in Chapter 4 and 5, the regression analyses should report both statistical and economic significance for the testing in the first two steps of Stage I.

Subsequently, in the third step, this study restricts the observations of the correlation examined in the second step to the year including and after 2007. Qualitative analysis shows that, since 2007, the EDS-related policies in Xinjiang are more frequent than before. Prior to 2007, major EDS-related policies are the incorporation of the XPCC 
and the first GWRD initiative. Since the year of 2007, two more initiatives of the GWRD roll out, in 2008 and 2013 respectively. In addition, from 2007 to 2014, every four years there is at least one new EDS-type initiative introduced, i.e. the LEP in 2007, the Paired Assistance Program (duikou yuanjiang, 对口援疆) in 2010, the Rapid Strike Program in 2014, and the Poverty Alleviation (jingzhun fupin, 精准扶贫) initiative in 2016 (The State Council Information Office of the People's Republic of China, 2016). Now that qualitative analysis has explored how the EDS-related polices lead to gendered changes migration and employment in the XUAR, should the hypothesized correlation between gendered migratory and employment patterns and the Uyghur-Han conflicts stands, the period since 2007 should see a more intense picture of Uyghur-Han conflicts following the SoS conflict patterns. Statistically, the parameters of interest will report a larger number than step two, while the correlation continues to be statistically significant.

If the third step confirms that since 2007 the Uyghur-Han conflicts are more intensely correlated with the ethnic attachment to land, this study will proceed to the fourth step, verifying whether this increased intensity can indeed be attributed to the gendered migratory and employment patterns, and if so, how the correlation works. Should such attribution be established, the regression analysis should be statistically and economically significant, with the coefficient parameter indicating how the correlation works.

Since economic well-being influences the migratory and employment patterns, both stages of testing should hold the economic performance of the XUAR constant. In Stage II, this study repeats all four steps in Stage I, adding a control variable that is an 
alternative reflection of the economic performance of the XUAR. By so doing, this study intends to test the validity of the correlation should this study find any in the first stage. Ideally, the correlation should stand holding this extra control variable constant, since it is simply a different way of depicting the economy of the XUAR of each year. For both stages, whether the correlation is statistically significant depends on whether the t-values abide by the commonly adopted benchmark values in statistics as outlined in Table 3 .

Table 3 Benchmark Values for Empirical Analysis ${ }^{30}$

\begin{tabular}{|c|c|c|c|c|c|c|}
\hline & \multicolumn{7}{|c|}{ Confidence Level } \\
\hline df & $60 \%$ & $70 \%$ & $80 \%$ & $90 \%$ & $95 \%$ & $99 \%$ \\
\hline 9 & 0.883 & 1.100 & 1.383 & 1.844 & 2.262 & 3.250 \\
\hline 14 & 0.868 & 1.076 & 1.345 & 1.761 & 2.145 & 2.977 \\
\hline 15 & 0.866 & 1.076 & 1.341 & 1.753 & 2.131 & 2.947 \\
\hline & \multicolumn{7}{|c|}{ T-value } \\
\hline
\end{tabular}

\subsubsection{Variables and Data Collection}

Throughout all steps of testing, the dependent variable (DV) is the frequency of Uyghur-Han conflict onsets per year. This study operationalizes this variable as count of incidents, which through cross referencing entries in academia and media the author has tabulated and presented in Table 2, Chapter 3. The count of incidents is coded by calendar year. For instance, from January $1^{\text {st }}$ to December 31st, 2014, there are 11 Uyghur-Han conflicts, the number 11 is input in the count of incident for 2014.

${ }^{30}$ Excerpted from T-table available from http://www.sjsu.edu/faculty/gerstman/StatPrimer/t-table.pdf (retrieved on February 26, 2018). 
The independent variable for the first step $\left(\mathrm{IV}_{1}\right)$ is the ethnic construction of the population of the XUAR, which this study operationalizes as the Uyghur/Han population ratio in the XUAR of the year. The Xinjiang Statistics Yearbooks produce the total count of Uyghur population and Han population in the XUAR in their publications of 1980, 1987, 1988-1990, and 1995-2015 (Statistics Bureau of Xinjiang Uyghur Autonomous Region, 2017). Using these statistics, this study calculates the Uyghur/Han population ratio. Since the XPCC conducts its own survey and census independent of the XUAR, this study also refers to the corresponding XPCC statistics and adds in to the calculation to reflect a true demographic picture (National Bureau of Statistics of the People's Republic of China, 2017)

For the second and third step, the independent variable $\left(\mathrm{IV}_{2}\right)$ is the ethnic attachment to land. To measure the importance of land rights graphed onto ethnic identities, this study creates an interaction term using the Uyghur/Han population ratio and the contribution of secondary industry to the GDP of the XUAR of the year. As Part I of this study explores, secondary industry revolves around the excavation and processing of natural resources, i.e. oil, gas, coal, etc., and associates closely with the Uyghur-Han conflicts. Under the conceptual framework of SoS conflicts, Uyghur's selfidentified indigeneity, as well as their perceived rights derived thereby to the land and its resources, are at the core of the Uyghur-Han conflict causal mechanism. Creating such an interaction term allows the variable to capture how ethnicity and attachment to land work in conjunction in contributing to the Uyghur-Han conflicts. Both data for 
population and the contribution of secondary industry to the GDP of the XUAR are available by year in the Xinjiang Statistics Yearbooks as well.

The lack of data transparency in China presents a challenge for the operation of the fourth step. Whereas the original plan is to present the gendered migratory pattern as the population flow by gender by year and the gendered employment pattern as the employment rate by gender by ethnicity by year, these statistics are not consistently available from the database of the Statistics Bureau of the XUAR or the National Statistics Bureau of the PRC. Data are available for number of female workers in public-funded institutions $^{31}$ in the XUAR (Statistics Bureau of Xinjiang Uyghur Autonomous Region, 2017). However, considering that the LEP and the RSPs mostly engage with private firms, this information is of limited use. Also, there is no information provided in terms of how many of these female workers are identified as Uyghur.

In this case, this study creates an interaction term between the female/male population ratio in the XUAR of the year and the Uyghur/Han population ratio in the XUAR of the year. The underlying logic is that those who have stable work are more likely to be registered in the population survey each year and the census every 10 years given the Chinese hukou (户口) population management system. By creating an interaction term using the two values, this study can provide a proximate picture and trace the pattern accordingly of the migration and employment of the female Uyghur in

31 feisiying danwei, 非私营单位, literally “non-privately-run work unit". 
the XUAR. Similar to $\mathrm{IV}_{1}$, the female/male population ratio in the XUAR of the year is calculated according to the population survey outcome available in the Xinjiang Statistics Yearbooks (Statistics Bureau of Xinjiang Uyghur Autonomous Region, 2017) with the data of the XPCC incorporated. However, as the data availability compromises the ideal research design, this study aims to model the conflict developmental trends in relation to the gendered policy outcomes, instead of precisely forecasting the conflict onsets.

Throughout Stage I, this study uses CPI as a control variable to reflect and account for the economic changes in the XUAR. In Stage II, this study opts to GDP per capita as a different method of evaluating the economic well-being of the XUAR. Putting GDP per capital into the test as an additional control variable serves three purposes: first, to test the robustness and the validity of the correlation, if any is found, in Stage I. Second, to compensate for the limited data of CPI; and third, since $\mathrm{IV}_{2}$ is associated with GDP, using GDP per capita as control variable may point to extra findings. The Xinjiang Statistics Yearbooks report CPI each year from 2000 to 2015, and GDP per capita from 1990 to 2015 (Statistics Bureau of Xinjiang Uyghur Autonomous Region, 2017).

Except for the dependent variable, when coding the data for independent variables and control variables, the input is lagged one year. For instance, the Uyghur/Han population ratio reported for the year 2010 is entered in such a way to match the count of violent incidents of the year 2011. This is out of the consideration that the Chinese population survey and census set their standard time as July $1^{\text {st }}$ if the projects are conducted prior to 2000, and November $1^{\text {st }}$ if the projects are conducted since 2000 (National Bureau of Statistics of People's Republic of China, 2016; People's Republic of 
China State Council , 2010). In this way, the demographics reported are more reflective of the situation closer to the year immediately after the survey or the census is conducted than the year of. More importantly, if not lagged, the correlation test would be unreasonable. The demographics changes occur on or after the date of standard time cannot possibility explain or contribute to the conflicts occur before the standard time. A majority of the coded conflicts in Table 2 take place before July, showing the need of the lagged input. Additionally, it is also reasonable to assume the demographics changes will not immediately result in the conflict onsets and thus further justifying this method.

Table 4 Summary of Variables

\begin{tabular}{|c|c|c|c|}
\hline Steps & \multicolumn{2}{|c|}{ Variables } & Operationalization \\
\hline $\begin{array}{l}\text { Stage I \& II: } \\
1-4\end{array}$ & $\begin{array}{l}\text { Dependent } \\
\text { Variable }\end{array}$ & $\begin{array}{l}\text { Frequency of Conflict } \\
\text { Onsets }\end{array}$ & Count of Incident by Year \\
\hline Stage I: 1 & \multirow{3}{*}{$\begin{array}{l}\text { Independent } \\
\text { Variables }\end{array}$} & $\begin{array}{c}\text { Ethnic Construction } \\
\text { of The XUAR } \\
\text { Population }\end{array}$ & $\begin{array}{l}\text { Uyghur/Han Population Ratio } \\
\text { in the XUAR of the Year }\end{array}$ \\
\hline Stage I: 2-3 & & $\begin{array}{l}\text { Ethnic Attachment to } \\
\text { Land }\end{array}$ & $\begin{array}{c}\text { Interaction Term: } \\
\text { Uyghur/Han Population Ratio } \\
\text { in the XUAR of the Year } \\
\text { *Secondary Industry } \\
\text { Contribution to GDP Of the } \\
\text { XUAR Of the Year }\end{array}$ \\
\hline Stage I: 4 & & $\begin{array}{c}\text { Gendered Migratory } \\
\text { and Employment } \\
\text { Patterns }\end{array}$ & $\begin{array}{c}\text { Interaction Term: } \\
\text { Female/Male Population Ratio } \\
\text { in The XUAR of the Year } \\
\text { *Uyghur/Han Population Ratio } \\
\text { in the XUAR of the Year }\end{array}$ \\
\hline $\begin{array}{l}\text { Stage I: } 1-4 \\
\text { Stage II: } 1-4\end{array}$ & \multirow{2}{*}{$\begin{array}{l}\text { Control } \\
\text { Variables }\end{array}$} & \multirow{2}{*}{$\begin{array}{c}\text { Economic Well-Being } \\
\text { of the XUAR }\end{array}$} & CPI of the Year \\
\hline Stage II: $1-4$ & & & GDP Per Capita of the Year \\
\hline
\end{tabular}




\subsection{Results and Discussion}

\subsubsection{The Uyghur-Han Conflicts and SoS Patterns}

Empirical evidence shows that the Uyghur-Han conflicts follow the SoS definition and conflict patterns. The first two steps of testing in Stage One report both statistical significance and economic significance. Detailed in Table 5, regression analysis results for step one show with close to $98 \%$ confidence level $(t=-2.59)$ that the frequency of conflicts correlates with the ethnic construction of the XUAR, holding economic performance of the XUAR constant. The slope (coefficient $=-124.2595$ ) indicates a negative relationship between the DV and the IV. That is to say, in general, the higher the Uyghur/Han population ratio, the fewer conflicts one can expect, ceteris paribus. Otherwise, the less homogeneous the ethnic construction it is, the more conflict-prone the region will be. This pattern corresponds with the SoS conflicts concept that the influx of migrants from other parts of the same country relates to the conflict breakouts (Côté \& Huang, 2017; Weiner , 1978). 
Table 5 Conflict Frequency and Uyghur/Han Population Ratio, 2001-2016 32

\begin{tabular}{|c|c|c|c|c|c|c|}
\hline Source & SS & $d f$ & MS & Number of obs & $=$ & 16 \\
\hline Model & 91.0869446 & 2 & 45.5434723 & Prob $>F$ & $=$ & 0.0021 \\
\hline Residual & 57.3505554 & 13 & 4.41158119 & R-squared & $=$ & 0.6136 \\
\hline & & & & Adj R-squared & $=$ & 0.5542 \\
\hline Total & 148.4375 & 15 & 9.89583333 & Root MSE & $=$ & 2.1004 \\
\hline
\end{tabular}

\begin{tabular}{r|rrrrrr}
\hline incidentco t & Coef. & Std. Err. & $t$ & $\mathrm{P}>|\mathrm{t}|$ & [95\% Conf. Interval] \\
\hline xuaruhrati t & $\mathbf{- 1 2 4 . 2 5 9 5}$ & $\mathbf{4 7 . 9 6 3 0 4}$ & $\mathbf{- 2 . 5 9}$ & $\mathbf{0 . 0 2 2}$ & $\mathbf{- 2 2 7 . 8 7 7 4}$ & $\mathbf{- 2 0 . 6 4 1 6 4}$ \\
cpi & .0884247 & .025628 & $\mathbf{3 . 4 5}$ & 0.004 & .0330587 & .1437908 \\
_cons & 67.48866 & 30.55123 & 2.21 & 0.046 & 1.486735 & 133.4906 \\
\hline
\end{tabular}

32 Economic model:

Count(s) of Incident $t=\alpha_{1} \frac{\text { Uyghur Population }_{t-1}}{\text { Han Poulation }_{t-1}}+\beta_{1} C P I+\varepsilon_{1}$

In STATA table,

incidentco $t=$ counts of incidents,

xuaruhrati $t=$ Uyghur/Han population ratio,

cpi=the CPI index with year of 1978 CPI value equals to 100 . 


\begin{tabular}{|c|c|c|c|c|c|c|}
\hline Source & SS & $d f$ & MS & Number of obs & $=$ & 15 \\
\hline Model & 113.430346 & 4 & 28.3575866 & Prob $>F$ & $=$ & 0.0024 \\
\hline Residual & 31.5029869 & 10 & 3.15029869 & R-squared & $=$ & 0.7826 \\
\hline & & & & Adj R-squared & $=$ & 0.6957 \\
\hline Total & 144.933333 & 14 & 10.352381 & Root MSE & $=$ & 1.7749 \\
\hline
\end{tabular}

\begin{tabular}{r|rrrrrr}
\hline incidentcont & Coef. & Std. Err. & $t$ & P $>|t|$ & [95\% Conf. Interval] \\
\hline eth_land & $\mathbf{2 5 6 . 7 7 7 9}$ & $\mathbf{1 7 4 . 1 3 7 3}$ & $\mathbf{1 . 4 7}$ & $\mathbf{0 . 1 7 1}$ & $\mathbf{- 1 3 1 . 2 2 4 2}$ & $\mathbf{6 4 4 . 7 8}$ \\
xuaruhrati t & $\mathbf{- 3 0 6 . 1 1 5 5}$ & $\mathbf{9 3 . 6 2 8 7 3}$ & $\mathbf{- 3 . 2 7}$ & $\mathbf{0 . 0 0 8}$ & $\mathbf{- 5 1 4 . 7 3 3 4}$ & $\mathbf{- 9 7 . 4 9 7 7 2}$ \\
sec_per & $\mathbf{- 2 3 5 . 0 1 7 5}$ & $\mathbf{1 5 9 . 3 8 8 5}$ & $\mathbf{- 1 . 4 7}$ & $\mathbf{0 . 1 7 1}$ & $\mathbf{- 5 9 0 . 1 5 7 1}$ & $\mathbf{1 2 0 . 1 2 2 1}$ \\
cpi & .1257018 & .0292406 & $\mathbf{4 . 3 0}$ & $\mathbf{0 . 0 0 2}$ & .0605498 & .1908539 \\
_cons & $\mathbf{2 1 3 . 1 3 8 9}$ & $\mathbf{7 9 . 5 7 9 3 7}$ & $\mathbf{2 . 6 8}$ & $\mathbf{0 . 0 2 3}$ & $\mathbf{3 5 . 8 2 5}$ & $\mathbf{3 9 0 . 4 5 2 8}$ \\
\hline
\end{tabular}

${ }^{33}$ Economic model:

Count of Incidents $t_{t}=\alpha_{2} \frac{\text { Uyghur Population }_{t-1}}{\text { Han Poulation }_{t-1}}+\beta_{2}$ CPI $_{t-1}+\gamma_{2} \frac{\text { Uyghur Population }_{t-1}}{\text { Han Poulation }_{t-1}} *$ Secondary Industry Contribution to GDP $P_{t-1}+\varepsilon_{2}$

In STATA table, eth_land=ethnic attachment to land, incidentco! $t=$ counts of incidents, xuaruhrati $t=$ Uyghur/Han population ratio, cpi=the CPI index with year of 1978 CPI value equals to 100 . 
Likewise, Table 6 summarizes and displays some empirical evidence for the correlation between ethnic attachment to the land and the frequency of conflicts, which step two tests. At the confidence level of $80-90 \%(t=1.47)$, the ethnic attachment to the land correlates with the conflict frequency. The slope (coefficient=256.7779) informs that this correlation is a positive one. The higher level the attachment is, the more conflictprone it will be, holding the economic performance constant. With some statistical significance, this positive correlation corroborates with the SoS literature. In SoS conflicts, the perceived infringement of the land and its resources is what triggers adversity from the people who consider themselves native to and therefore the righteous owners of the land. Empirical evidence indicates that the Uyghur-Han conflicts display this typical SoS pattern.

\subsubsection{Influence of the EDS on The Uyghur-Han Conflicts}

When limited to the period of 2007 to 2017, the Uyghur-Han conflicts show more prominent SoS conflict patterns. A comparison of the coefficients reported in Table 6 and Table 7 ( $\gamma_{2}$ and $\gamma_{3}$ in corresponding economic models) reveals that the ethnic attachment to land has a stronger influence on the frequency of conflicts in 2007-2016 than in 20012016 , controlling for CPI. The influence more than doubles in the past decade $\left(\gamma_{2}=256.7779\right.$ and $\left.\gamma_{3}=545.1519\right)$. Step three of the testing also reports a higher $\mathrm{t}$-value $(\mathrm{t}=1.94)$, thus given us a confidence level of over $90 \%$, which is higher than what step two reports. In other words, the ethnic and indigenous components not only play an important role in the Uyghur-Han conflicts, but also have a growing importance in the past decade than before. 
By now, empirical evidence has suggested that Uyghur-Han conflicts are highly compatible with the SoS conflicts, corroborating with the literature review in Chapter 4 and 5. In the Uyghur-Han conflicts, the ethnic, indigenous, and land components yield essential influence in the conflict mechanisms as what SoS literature prescribes. More importantly, empirical evidence has alluded to the hypothesis that the gendered migratory and employment patterns - as discussed, consequent to the EDS-related policies - aggravate the Uyghur-Han conflicts.

In detail, the empirically observed augmented prominence of the correlation between the ethnic attachment to land and the frequency of conflicts - corresponds with the rise in ethnic violence summarized in Chapter 3. This empirical observation also corroborates with qualitative analysis of the correlation between the gendered policy outcome and the rise in ethnic violence examined in Chapter 6.

In 2007-2016, the influence of ethnic attachment of land over the frequency of conflicts more than doubles. During the same period, one observes the hike of conflicts, as depicted in Figure 4. Since the economic performance of the XUAR has been held constant, and that the variables are the same in both steps of testing, such changes in the strength of the influence of the ethnic attachment to land indicate that the economic models in step two and three have not incorporated factors that can explain the intensification of the correlation.

In addition, given that the changes occur when the years of observation alter, it is reasonable to hypothesize that the yet-to-be captured factors influencing the changes has a temporal element. This observation corroborates with the hypothesis that the gendered 
migratory and employment patterns aggravate the Uyghur-Han conflicts, given that since 2007, the more intensive EDS has shown correlation with more gendered impacts in population movement and work in the XUAR than in 2001-2007.

Table 7 Conflict Frequency and Ethnic Attachment to Land, 2007-201634

\begin{tabular}{|c|c|c|c|c|c|c|}
\hline Source & SS & $d f$ & MS & Number of obs & $=$ & 10 \\
\hline & & & & $F(4,5)$ & $=$ & 6.77 \\
\hline Model & 98.6865753 & 4 & 24.6716438 & Prob > F & $=$ & 0.0298 \\
\hline Residual & 18.2134247 & 5 & 3.64268494 & R-squared & $=$ & 0.8442 \\
\hline & & & & Adj R-squared & $=$ & 0.7196 \\
\hline Total & 116.9 & 9 & 12.9888889 & Root MSE & $=$ & 1.9086 \\
\hline
\end{tabular}

\begin{tabular}{r|rrrrrr}
\hline incidentco t & Coef. & Std. Err. & $t$ & P > t l & [95\% Conf. Interval] \\
\hline eth_land & 545.1519 & 280.3165 & 1.94 & 0.109 & -175.4246 & 1265.728 \\
xuaruhrati t & -498.643 & 159.59 & -3.12 & 0.026 & -908.8821 & -88.40392 \\
sec_per & -516.8157 & 265.896 & -1.94 & 0.110 & -1200.323 & 166.6918 \\
cpi & .1601452 & .0363724 & 4.40 & 0.007 & .0666471 & .2536434 \\
_cons & 378.9961 & 141.0995 & 2.69 & 0.044 & 16.28829 & 741.7039 \\
\hline
\end{tabular}

With the potential of the hypothesis implied, step four proceeds. Results of the regression analysis of the proposed correlation between the gendered migratory and

${ }^{34}$ Economic model:

Count of Incidents $t_{t}=\alpha_{3} \frac{\text { Uyghur Population }_{t-1}}{\text { Han Poulation }_{t-1}}+\beta_{3}$ CPI $_{t-1}+\gamma_{3} \frac{\text { Uyghur Population }_{t-1}}{\text { Han Poulation }_{t-1}} *$ Secondary Industry Contribution to $G D P_{t-1}+\varepsilon_{3}$

In STATA table, eth_land=ethnic attachment to land, incidentco! $t=$ counts of incidents, xuaruhrati $\sim=\mathrm{Uyghur} / \mathrm{Han}$ population ratio, cpi=the CPI index with year of 1978 CPI value equals to 100 . 
employment patterns and frequency of conflicts are promising. As Table 7 reports, the correlation is a positive one at a confidence level of close to $70 \%$. The value of the parameter also indicates strong economic significance. Given that the gendered migratory and employment patterns is measured by an interaction term reflection female/male population ratio and Uyghur/Han population ratio in the XUAR, one can infer from the regression analysis results that the more Uyghur women at work, the more conflict-prone the region will be. This result echoes the discussion in Chapter 5, which explores Uyghur women's economic empowerment challenges existing Uyghur patriarchal value and order, threatening men's interests, and therefore fuelling Uyghur men's resentment to EDS and the Han-dominant government proposing the policies.

More importantly, this step suggests the significance of adopting the gender aspect in solving the Uyghur-Han conflicts. As Figure 6 shows, in the past decade, the Uyghur/Han population ratio in the XUAR is steadily rising. Should the Uyghur-Han conflicts be pure ethnic struggles, the increased homogeneity of the population should bring a more peaceful time. On the contrary, the past decade witnesses a rise of interethnic violence in Xinjiang. It is noteworthy that whereas the Uyghur-Han ratio is on rise, the female-male ratio experiences a harsh decrease between 2010 and 2011, before slowly rising back to its previous level. Coincidentally, it is also starting around 2010 that the Uyghur-Han conflict frequency takes a hike. And, as the result of step four reveal, this change in the gender construction of the population does indeed correlate - instead of coinciding - with the hike of conflict outbreaks. 
The correlation does not necessarily stand for a causation. Indeed, although the gendered changes resulted from the EDS correlate with the conflict outbreaks, it could be the reverse of what the study hypothesizes. In other words, instead of gendered employment and migratory patterns contributing to the conflicts, it could be that these gendered patterns are due to the conflicts. For example, it could be out of fear of conflicts that Uyghur women leave the XUAR.

Figure 6 Population Construction Changes in the XUAR, 2001-2016

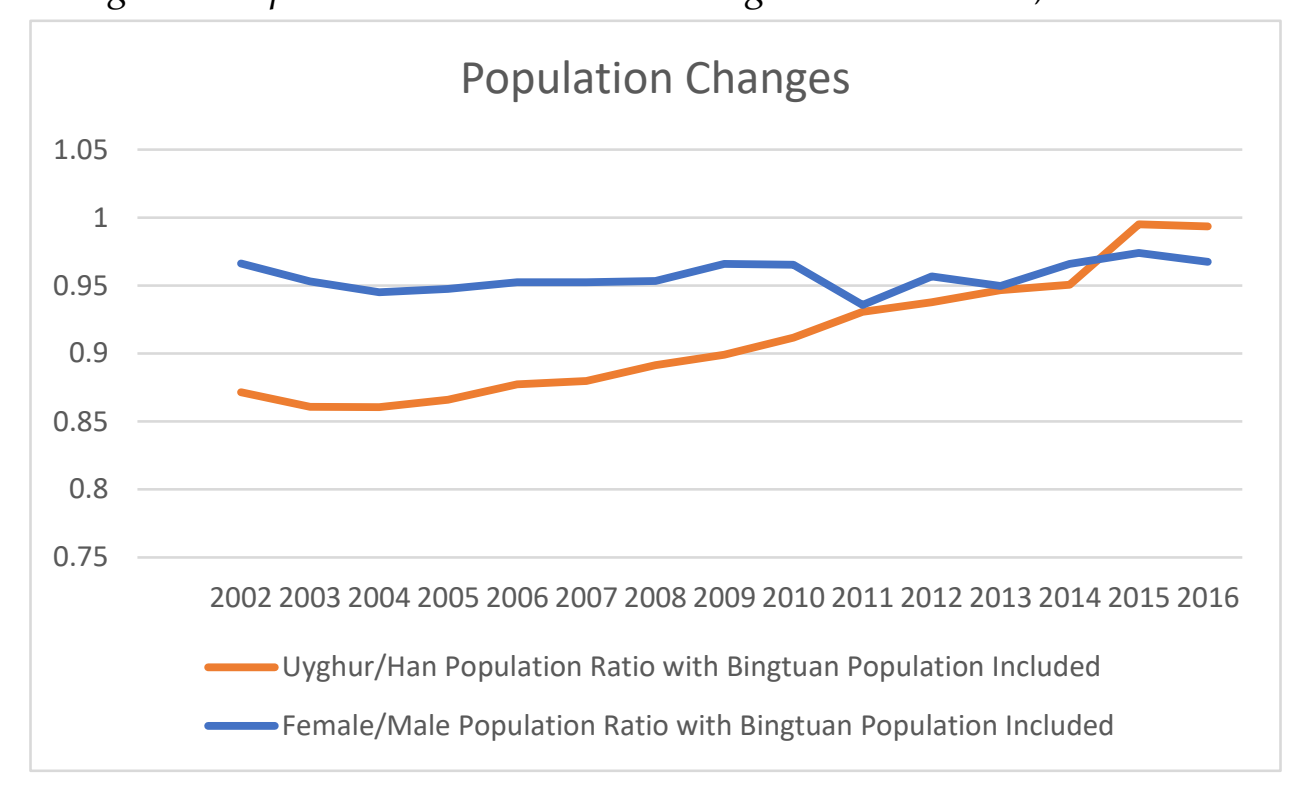

Looking at the statistics one can infer that there is rather low possibility that the reversed relation establishes. For instance, from 2010 to 2011, the count of conflicts increases. However, from 2011 to 2012, the female/male population ratio rises. This also holds true for the 2012-2013 and 2013-2014 observations: in the year immediately after a rise in conflict onsets occurs, there is no reactionary drop in female/male population ratio. Hence, it is more likely that the EDS-induced gendered employment and migratory patterns give rise to the Uyghur-Han conflicts than the other way around. 


\subsubsection{Verifying Quantitative Findings}

Comparing the results in the first step from both stages, one can ensure the validity of the correlation found regarding the frequency of the conflicts and the ethnic construction of the XUAR. When the economic model includes an alternative indicator of the economic performance, the correlation remains its statistic and economic significance. At this step, both stages of testing report a negative relationship between the two variables. Since the parameters fall in similar range, the influence of the ethnic construction over the frequency of the conflicts is consistent regardless of the method of measuring economic performance of the region. Plotting the residuals over fitted values for this step at both stages, one finds that the residuals are not randomly distributed. Such distribution indicates that ethnic construction alone does not capture or explain the variation, and thus confirms the need of further testing and expanding the economic model to include more explanatory variables. 
Table 8 Conflict Frequency and Uyghur/Han Population Ratio, 2001-2016, with GDP Per Capita Added 35

\begin{tabular}{r|cccllr} 
Source & SS & df & MS & Number of obs & $=$ & 16 \\
& & & & $F(3,12)$ & $=$ & 7.14 \\
Model & $\mathbf{9 5 . 1 6 0 0 8 6 5}$ & 3 & 31.7200288 & Prob $>F$ & $=$ & 0.0052 \\
Residual & $\mathbf{5 3 . 2 7 7 4 1 3 5}$ & 12 & 4.43978446 & R-squared & $=$ & 0.6411 \\
& & & & Adj R-squared & $=$ & 0.5513 \\
Total & 148.4375 & 15 & 9.89583333 & Root MSE & $=$ & 2.1071
\end{tabular}

\begin{tabular}{r|rrrrrr}
\hline incidentco t & Coef. & Std. Err. & $t$ & $\mathrm{P}>|\mathrm{t}|$ & [95\% Conf. & Interval] \\
\hline xuaruhrati t & -139.3484 & 50.62935 & -2.75 & 0.018 & -249.6603 & -29.03657 \\
gdp & .0004126 & .0004308 & 0.96 & 0.357 & -.000526 & .0013512 \\
cpi & .0378024 & .0587732 & 0.64 & 0.532 & -.0902534 & .1658582 \\
_cons & 99.62941 & 45.44624 & 2.19 & 0.049 & .6105708 & 198.6483 \\
\hline
\end{tabular}

35 Economic model:

Count $(s)$ of Incident $_{t}=\alpha_{5} \frac{\text { Uyghur Population }_{t-1}}{\text { Han Poulation }_{t-1}}+\beta_{5}$ CPI $+\theta_{5}$ GDP per capita $+\varepsilon_{5}$

In STATA table, incidentco! $t=$ counts of incidents, xuaruhrati $t=$ Uyghur/Han population ratio, cpi=the CPI index with year of 1978 CPI value equals to 100. 
Table 9 Conflict Frequency and Ethnic Attachment to Land, 2001-2016, GDP Per Capita Added ${ }^{36}$

\begin{tabular}{|c|c|c|c|c|c|c|}
\hline Source & SS & $d f$ & MS & Number of obs & $=$ & 15 \\
\hline Model & 119.122599 & 5 & 23.8245198 & Prob $>F$ & $=$ & 0.0035 \\
\hline Residual & 25.8107341 & 9 & 2.86785934 & R-squared & $=$ & 0.8219 \\
\hline Total & 144.933333 & 14 & 10.352381 & $\begin{array}{l}\text { Adj R-squared } \\
\text { Root MSE }\end{array}$ & $\begin{array}{l}= \\
=\end{array}$ & $\begin{array}{l}0.7230 \\
1.6935\end{array}$ \\
\hline
\end{tabular}

\begin{tabular}{r|rrrrrr}
\hline incidentcout & Coef. & Std. Err. & $t$ & P $|t|$ & [95\% Conf. Interval] \\
\hline eth_land & 235.7381 & 166.8177 & 1.41 & 0.191 & -141.6298 & 613.106 \\
xuaruhrati t & -319.8659 & $\mathbf{8 9 . 8 6 4 6 4}$ & -3.56 & 0.006 & -523.1538 & -116.5779 \\
sec_per & -215.9879 & 152.6744 & -1.41 & 0.191 & -561.3614 & 129.3856 \\
cpi & .0683955 & .0493244 & 1.39 & 0.199 & -.043184 & .1799751 \\
gdp & .000494 & .0003507 & 1.41 & 0.192 & -.0002992 & .0012873 \\
_cons & 245.9647 & 79.42282 & 3.10 & 0.013 & 66.29777 & 425.6316 \\
\hline
\end{tabular}

${ }^{36}$ Economic model:

Count of Incidents $s_{t}=\alpha_{6} \frac{\text { Uyghur Population }_{t-1}}{\text { Han Poulation }_{t-1}}+\beta_{6}$ CPI $_{t-1}+\gamma_{6} \frac{\text { Uyghur Population }_{t-1}}{\text { Han Poulation }_{t-1}} *$ Secondary Industry Contribution to GDP $P_{t-1}+\theta_{6} G D P$ per capita $+\varepsilon_{6}$

In STATA table,

eth_land=ethnic attachment to land, incidentco! $t=$ counts of incidents,

xuaruhrati $t=\mathrm{Uyghur} /$ Han population ratio, $g d p=$ GDP per capita, cpi=the CPI index with year of 1978 CPI value equals to 100. 
Likewise, step two in Stage Two of the testing report results that confirm the correlation found in Stage One. Namely, ethnic attachment to the land has a statistically and economically significant correlation with the frequency of conflict, despite the additional variable. The sign of the correlation corresponds with that reported in the second step of Stage One. Ethnic attachment to the land positively correlates to the outbreak of conflicts whether the economic well-being of the region is captured by CPI or GDP per capita. Still, residuals at this step for both stages do not distribute randomly, pointing to the need of additional explanatory factors.

When limited to the period of 2007-2016, the observed correlation still holds with the additional variable. However, a comparison of the same step in different stages reveals that with GDP per capita included into the economic model, the correlation found is less statistically significant. The confidence level drop from the range of $90-95 \%$ to the range of $60-70 \%$. In addition, the correlation in this step is less economically significant. Dropping from 545.1519 to 325.535 , the changes in the parameter indicates that the influence of ethnic attachment to the land is not as strong when the economic model takes into account the GDP per capita of the XUAR. 
Table 10 Conflict Frequency and Ethnic Attachment to Land, 2007-2016, GDP Per Capita Added ${ }^{37}$

\begin{tabular}{|c|c|c|c|c|c|c|}
\hline Source & SS & $d f$ & MS & Number of obs & $=$ & 10 \\
\hline Model & 102.697149 & 5 & 20.5394298 & Prob > F & $=$ & 0.0569 \\
\hline Residual & 14.2028511 & 4 & 3.55071277 & R-squared & $=$ & 0.8785 \\
\hline Total & 116.9 & 9 & 12.9888889 & Root MSE & $=$ & 1.8843 \\
\hline
\end{tabular}

\begin{tabular}{r|rrrrrr}
\hline incidentco t & Coef. & Std. Err. & $t$ & $\mathrm{P}>|\mathrm{t}|$ & [95\% Conf. & Interval] \\
\hline eth_land & 325.535 & 345.3905 & 0.94 & 0.399 & -633.4228 & 1284.493 \\
xuaruhrati t & -408.6132 & 178.8907 & -2.28 & 0.084 & -905.2935 & 88.06707 \\
sec_per & -304.8159 & 329.7062 & -0.92 & 0.408 & -1220.227 & 610.5952 \\
cpi & .0806661 & .0829588 & 0.97 & 0.386 & -.1496645 & .3109967 \\
gdp & .0006171 & .0005806 & 1.06 & 0.348 & -.000995 & .0022291 \\
_cons & 320.6036 & 149.7502 & 2.14 & 0.099 & -95.16955 & 736.3767 \\
\hline
\end{tabular}

${ }^{37}$ Economic model:

Count of Incidents I $_{t}=\alpha_{7} \frac{\text { Uyghur Population }_{t-1}}{\text { Han Poulation }_{t-1}}+\beta_{7}$ CPI $_{t-1}+\gamma_{7} \frac{\text { Uyghur Population }_{t-1}}{\text { Han Poulation }_{t-1}} *$ Secondary Industry Contribution to GDP $P_{t-1}+\theta_{7} G D P$ per capita $+\varepsilon_{7}$

In STATA table,

eth_land=ethnic attachment to land,

incidentco! $t=$ counts of incidents,

xuaruhrati $t=$ Uyghur/Han population ratio,

$g d p=$ GDP per capita,

cpi=the CPI index with year of 1978 CPI value equals to 100 . 
Table 11 Conflict Frequency and Gendered Migration and Employment, 2007-2017, GDP Per Capita Added ${ }^{38}$

\begin{tabular}{|c|c|c|c|c|c|c|}
\hline Source & SS & $d f$ & MS & Number of obs & $=$ & 10 \\
\hline Model & 105.376031 & 7 & 15.0537187 & Prob $>F$ & $=$ & 0.3046 \\
\hline Residual & 11.5239688 & 2 & 5.76198439 & R-squared & $=$ & 0.9014 \\
\hline Total & 116.9 & 9 & 12.9888889 & $\begin{array}{l}\text { Adj R-squared } \\
\text { Root MSE }\end{array}$ & $\begin{array}{l}= \\
=\end{array}$ & $\begin{array}{l}0.5564 \\
2.4004\end{array}$ \\
\hline
\end{tabular}

\begin{tabular}{r|rrrrrr}
\hline incidentco t & Coef. & Std. Err. & $t$ & P $>|t|$ & [95\% Conf. & Interval] \\
\hline gen_ethn & 3909.569 & 16560.59 & 0.24 & 0.835 & -67344.92 & 75164.06 \\
eth_land & 309.852 & 445.3109 & 0.70 & 0.559 & -1606.166 & 2225.87 \\
fmratiowit t & -3733.158 & 15582.64 & -0.24 & 0.833 & -70779.85 & 63313.54 \\
xuaruhrati t & -4188.598 & 16026.7 & -0.26 & 0.818 & -73145.92 & 64768.73 \\
sec_per & -294.2678 & 423.2206 & -0.70 & 0.559 & -2115.239 & 1526.704 \\
cpi & .1814967 & .4031813 & 0.45 & 0.697 & -1.553252 & 1.916246 \\
gdp & .0001346 & .0019621 & 0.07 & 0.952 & -.0083074 & .0085766 \\
_cons & 3884.921 & 14905.36 & 0.26 & 0.819 & -60247.65 & 68017.49 \\
\hline
\end{tabular}

${ }^{38}$ Economic model:

Count of Incidents $t_{t}=\alpha_{8} \frac{\text { Uyghur Population }_{t-1}}{\text { Han Poulation }_{t-1}}+\beta_{8} C P I_{t-1}+\gamma_{8} \frac{\text { Uyghur Population }_{t-1}}{\text { Han Poulation }_{t-1}} *$

Secondary Industry Contribution to $G D P_{t-1}+\delta_{8} \frac{\text { Female Population }_{t-1}}{\text { Male Poulation }_{t-1}} *$

$\frac{\text { Uyghur Population }_{t-1}}{\text { Han Poulation }_{t-1}}+\theta_{8} G D P$ per capita $+\varepsilon_{8}$

In STATA table,

gen_ethn=gendered migratory and employment pattern,

eth_land=ethnic attachment to land, incidentco! $t=$ counts of incidents,

xuaruhrati $t=\mathrm{Uyghur} / \mathrm{Han}$ population ratio,

$g d p=$ GDP per capita,

cpi=the CPI index with year of 1978 CPI value equals to 100. 
Unfortunately, in the final step, Stage Two testing can, at best, provide partial endorsement of the correlation between the gendered migratory and employment patterns and the frequency of conflicts. As Table 13 reports, the correlation is still a positive relationship when the economic model includes GDP per capita, showing the same trend as in Stage One. However, the parameter of interest drops, and even more so does the confidence level. At this stage, one can no longer observe the correlation with statistical significance. However, plotting the residuals over fitted values for this step for both stages, the graph shows a random distribution. In other words, the economic models in the fourth step in both stages capture the explanatory factors that can influence the frequency of conflicts.

\subsubsection{Accounting for the Discrepancies with FPE}

The residual-over-fitted-value plots indicate that the proposed economic models in step four for both stages have included meaningful variables that would explain the variation of the conflict onsets. Unfortunately, as discussed the data availability problem prevents this study from capturing all of the explanatory variables.

Comparing all four steps in both stages, one can infer that the ethnic construction and the ethnic attachment to the land are insufficient in predicting the changes in the frequency of the conflicts between the Uyghur and the Han. The addition of gendered migratory and employment patterns to the economic model is necessary and beneficial for understanding the Uyghur-Han conflict causal mechanisms. 
Figure 7 Residuals-Fitted Values Plot ${ }^{39}$

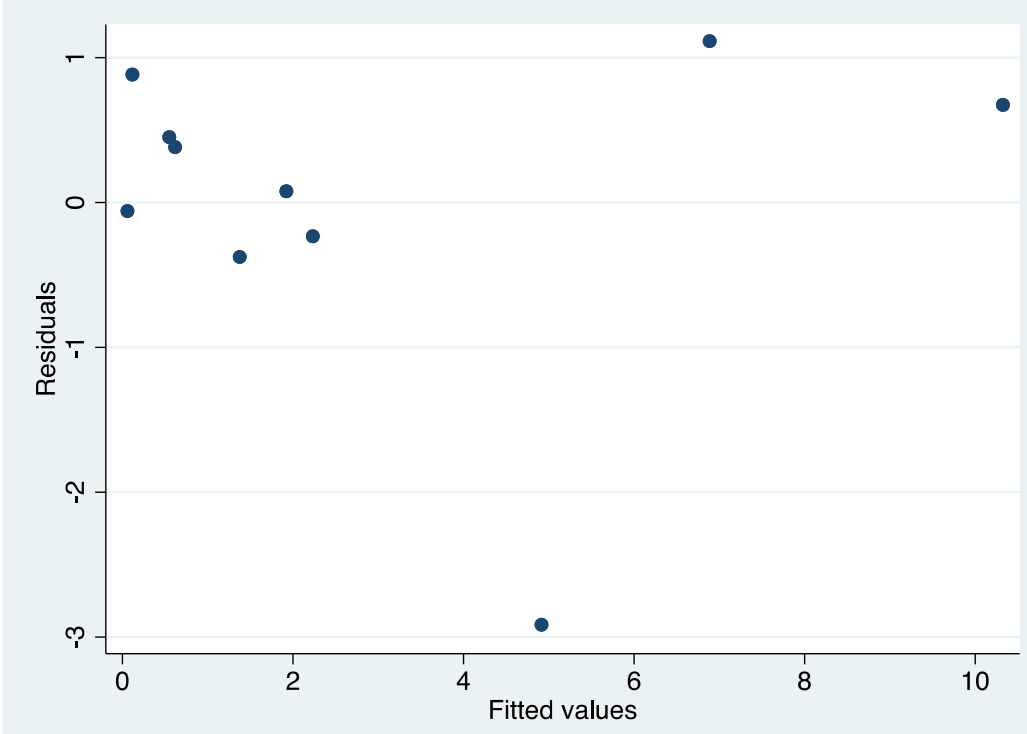

Even so, it is important to explore what causes the discrepancies between the two stages in the last two steps. There are two approaches to this issue. For one, on the statistics front, the dataset in the last two steps are small. Therefore, it is understandable that it can hardly fit the requirement for a statistical dataset - a compilation of aggregate data with high quantity and quality.

For the second, it is useful to consider the concept of GDP and its compatibility with the assumptions based on which the economic models run. Feminist Political Economy (FPE) has established how conventional account divides economic activities into two realms: productive economy and reproductive economy. The mainstream, productive economy focuses on waged labour, and often ignores the non-waged labour

${ }^{39}$ Of the economic model of Stage II step four. 
that involves both the "symbolic [and] material processes required to reproduce human beings over time - daily and intergenerationally-and the social relations of power within which these processes are embedded (Sen 1996, 828)" (Peterson, 2003, p. 79)

This "typical neglect" (Peterson, 2003, p. 46) of reproductive labour-often constructed as women's roles and duties - reveals in the operationalization of GDPrelevant statistics in international and national accounts. Pursuant to the standards set by the UN, the National Statistics Bureau of China does not consider domestic economic activities when calculating GDP, for instance, "home-based production, care work, gardening, neighbourhood project...streetside selling" (Peterson, 2003, p. 86; United Nations, 2008; Standardization Administration of the People's Republic of China, 2017) Regrettably, forgetting that the reproductive economy connects, interacts, and supports the productive economy, such a measure cannot fully reflect the economic performance of a country or a region. Aggravating the issue is that China's national account of GDP focuses on legal and institutional entities (National Bureau of Statistics of the People's Republic of China, 2017). That is to say, home-based production is even more likely to be out of the statistical survey. Taken together, the operationalization and calculation of GDP easily exclude women's participation and contribution to the economy if they work at or via home, which is very common (Peterson, 2003), making GDP less than an ideal reflection of the economic activities that women participate in. 


\section{Conclusion: A Critical Approach to Interethnic Conflicts}

\subsection{Revisiting Study Findings in the Uyghur-Han Conflicts}

After military force, cultural assimilation, and political co-option failed to pacify the Uyghur, the Chinese government adopted the economic development strategy in an attempt to reduce Uyghur-Han conflicts. It was hoped that improved economic wellbeing would increase the loyalty of the Uyghur people toward the Han-dominated Chinese state. As a result, the Chinese government would ensure its access to and control of Xinjiang, a vast territory with abundant natural resources. The region is also valuable for geopolitically important partnerships in Eurasia. Both are essential for China to continue and expand its development and global influence.

Unfortunately, a tabulation of the Uyghur-Han conflicts occurred in the past four decades vividly displays conflict development contrary to the goals of the EDS. Despite policy preferences given to the XUAR and capital and human resources investment into the region, the Uyghur-Han conflicts have escalated within the past decade compared with in previous eras, both in terms of the scale and the frequency of the conflicts. Contrary to the policy prescription, since 2010, when the EDS-related policies have been expanding, so are the Uyghur-Han conflicts have been rising.

Why is the EDS inefficient in addressing the Uyghur-Han conflicts? This study has argued that the gendered employment and migratory patterns resulted from the EDS whether an intentional policy outcome or not - has an important role to play. The Uyghur-Han relationship struggles from its Horizontal Inequalities (HIs), that is, the unequal distribution of political, socio-economic, cultural power and influence that 
favour the Han over the Uyghur. While the HIs are already fuelling the grievances the Uyghur community have against the Han, the gendered employment and migratory patterns exacerbate this problem.

An examination of the census and population survey results reveals fluctuations of ethnic and gender construction of the XUAR population that coincide with the Uyghur-Han onset patterns. In addition, existing literature has proposed criticisms from a gender perspective to similar EDS projects conducted by international organizations and other states. In all, these findings support a gender approach to the EDS and its efficacy in the Uyghur-Han cases. Furthermore, the departure of traditional ethnic conflicts and civil war characteristics has compelled this study to examine the UyghurHan conflicts in a new lens different from the traditional framework.

Therefore, this study has adopted the concept of the "Sons of the Soil" (SoS) conflicts and the Feminist Political Economy (FPE) as a critical approach to the inefficacy of EDS in the Uyghur-Han struggles. In comparison with traditional ethnic conflict and civil war, this study has shown that the definition of the SoS conflicts better suits the case of the Uyghur-Han conflicts. For instance, in SoS conflict, ethnic identity is no longer the sole, key determinant of conflict organization and mobilization; the definition incorporates the temporal importance of ethnic groups' arrival; it also calls attention to land and migration, the two factors that are only at times studied in traditional ethnic conflicts and civil wars but are essential to the Uyghur-Han conflicts. Treating the Uyghur-Han conflicts as typical SoS cases also solve the embarrassment that, due to theoretical and operational definitions, the civil war studies usually ignore or 
miscategorize these prolonged conflicts with low-level casualties. Meanwhile, the use of FPE has better enabled the study to probe how gender stereotypes and the resulting exploitation of women influence the conflict organization and mobilization, and subsequently hinder the EDS in the Uyghur-Han conflicts.

Informed by both the qualitative and quantitative analyses, this study has shown that there is a correlation between the gendered EDS policy outcomes and the UyghurHan conflict outbreaks. From the late 1980s to the mid-2000s, China's EDS-related policies in Xinjiang centred on attracting capital and labour to propel the industrialization and modernization in the XUAR. Due to the heavy-duty nature of work - mostly construction of infrastructure or resource excavation directed by the Xinjiang Production and Construction Corps (XPCC) and the Great Western Region Development (GWRD) - and the gender segregation of occupation the XUAR experienced a massive influx of male and Han dominant migrants from during the 1990s and mid-2000s. Empirical evidence shows that the increased gender ratio of the Xinjiang population correlates with the increase of Uyghur-Han conflicts. This relationship can be attributed to the presence of a large amount of Han men not who became the Xinjiang locals' perceived menaces to their economic security and personal safety. Han men have long enjoyed more favourable employment opportunities and compensation than the Uyghur men and women. Pushing other men into unemployment, or at times themselves unemployed but refusing to leave, these Han men become a perceived risk to Xinjiang's public security. In this regard, the popular gender biases that men are boisterous have a role in influencing social perception. In addition, the gender imbalance in the population, and the consequent lack 
of female companionship also contribute to the HIs and worsen the Uyghur-Han relationship, giving rise to conflicts (Côté, 2011).

In contrast with the masculinization of incoming Han migrants is the feminization of the outgoing Uyghur migrants starting in mid 2000s. Since 2004, the XUAR, in partnership with other provincial governments and business, start sending their surplus labour away. The Labour Export Program (LEP) marks the beginning of a new phase of EDS policies in which the focus shifts to solving local unemployment. Given the labourintensive work and the gender stereotype-informed preference for female workers, the employment and migration resulted from the EDS policies favour Uyghur women over men. As a result, the female Uyghur population continues decreasing, further increasing the male/female population ratio which is already rendered problematic under the Xinjiang Production and Construction Corps (XPCC) and the Great Western Region Development (GWRD) before mid 2000s. Moreover, the feminization of Uyghur migration existing the XUAR challenges the sense of reproductive security of the Uyghur community. For the patriarchal Uyghur society, Uyghur women that leaves Xinjiang for work put their virginity, and thus the reproduction of the pure, next Uyghur generation, at risk. Exacerbating the challenges to the patriarchal order, values, and interests is the Rapid Strike Projects (RSPs). Similar stereotypical preferences for female workers as those observed under the LEP render the RSPs a lopsided favour for Uyghur women and marginalize Uyghur men. Therefore, the RSPs inflame the grievances among Uyghur society against the EDS and the Han-dominant state. 
The notion that gender imbalance in employment and migration aggravates the interethnic hostilities has found support not only in the survey of policy outcomes and the reading of impact group's emotion and reaction. Empirical evidence has also suggested that the tilting of the gender balance, when graphed onto the ethnic division already in place, highly correlates with the frequency of the conflicts. As the strength of this correlation rises along with the intensity of the EDS-related policies, whose gendered outcome already shown, this study is positive that the EDS-induced gender employment and migratory patterns correlate with the Uyghur-Han conflict outbreak frequency. Additionally, this study has excluded the possibility that the gendered patterns are responses to conflicts. In this case, the qualitative findings are also empirically informed. The economic development strategy and its relevant policies result in gendered employment and migratory patterns, i.e. the masculinization of the in-coming migratory flow until the mid-2000s, the feminization of the out-flowing migratory flow since the mid-2000s, and the advantageous employment opportunities for Uyghur women since the mid-2000s. Subsequently, these gendered employment and migratory patterns intertwine with the existing Uyghur-Han inequalities and popular gender stereotypes, challenge the perception of the continuance of the Uyghur identity and society, and thereby aggravate the existing interethnic grievances and contribute to the Uyghur-Han conflicts. 


\subsection{Contemplating Future Research}

Adopting a gender perspective is a rather recent approach in the studies of migration and conflicts - be they internal or international. Indeed, for a long time, women have been relegated to the background of the world economic system, and therefore, the simultaneous exploitation of them by the capitalist and patriarchal social orders has been largely invisible (Wallerstein, 1974; Waring, 1988). However, the study of Uyghur-Han conflicts shows that taking a gender perspective in migration and conflict analyses is necessary and beneficial. Although not targeting gender problems, a policy can still have gender impacts, which, when ignored, can undermine the policy objectives.

The Uyghur-Han conflicts are not the only cases in which gendered employment and migratory patterns are present and influential to the conflict organization, mobilization, and development. In Southeast Asia, where the "Sons of the Soil" conflicts - the type of conflicts that share the complexity with the Uyghur-Han cases - are the most intense in the world, one can easily observe similar gendered patterns as a result of development policies. For instance, in the Riau Archipelago of Indonesia, the southern tip of Thailand, and the Province of Baluchistan of Pakistan, feminization of work and migration is a new and growing trend (Côté \& Huang, 2017; Tsuneda, 2009; Sudarshan \& Mukhopadhyay, 2003; Barter \& Côté, 2015).

Influenced by the moving of global production chain and the export-led development strategy, employment opportunities are shifting towards informalized work in the tertiary industry (Sudarshan \& Mukhopadhyay, 2003; Peterson, 2003; Peterson, 2010). Such shifts are in favour of female labour forces. Compatible with the 
Uyghur-Han cases, in Southeast Asia, employers tend to hire women, who they perceive to be docile and obedient, to fill the export-oriented labour-intensive positions (Côté \& Huang, 2017). In the meantime, as "an increasing proportion of jobs" requires labour "available for part-time and temporary work, and willing to accept low wages" (Peterson, 2003, p. 61), more women than men tend to pick up these informalized jobs. Studies also find that development policies tend to displace small farmers, who are mostly male (Sudarshan \& Mukhopadhyay, 2003; Peterson, 2010; Peterson, 2003), and thus cornering men in the plight of unemployment. Corroborating the study in the Uyghur-Han conflicts, recent studies on Indonesia shows gender imbalance in the population consequent to migration has given rise to SoS-typed conflicts (Barter \& Côté, 2015; Côté \& Huang, 2017). How would gender imbalance in migration and employment pan out in other SoS conflicts? The wide applicability, potential explosion, and outstanding impact (Fearon \& Laitin, 2011; Weiner , 1978) of the SoS conflicts merit further exploration on the correlation between gendered outcomes consequent to development policies and the outbreak of migration-based interethnic conflicts in more case studies.

Despite the gendered policy outcomes and their association with conflict outbreaks, this study is not suggesting that economic development policies which benefit women should be stopped. The real contributing factor to the conflict outbreaks is not the benefits women derive from the policies, but the patriarchal social order and its adherents' perceived insecurity. In fact, although the EDS has empowered Uyghur women to a certain extent, Uyghur women remain disadvantaged and exploited. Despite the employment promotion initiatives discussed hitherto, Uyghur women still receive 
significantly lower pay than Han employees and Uyghur men. Families are less supportive for their daughters of educational and career pursuit, which in turn hinders the daughters' financial stability and economic well-being. Even when Uyghur women pick up work, they still face double exploitation: they have to continue fulfilling their socalled household duties, while receiving relatively low pay from the labour-intensive work (Zang, 2012; Peterson, 2010). Therefore, it is essential to address the patriarchy and gender parity, both as a means to improve the efficacy of the economic development strategy, and as an end in itself. 


\section{Bibliography}

People's Daily, 2013. 坚决打击“三股势力” (Firmly Attacks "Three Evils"). 人民日报 People's Daily, 1 July .

9th National People's Congress, 2001. 国民经济和社会发展第十个五年计划纲要 (the 10th Five-Year Planning on National Economy and Social Development). Beijing: s.n.

Abramson, K., 2012. Gender, Uyghur Identity, and the Story of Nuzugum. The Journal of Asian Studies, 71(4), pp. 1069-1091.

African Union, 2005. Policy on Post-Conflict Resolution and Devlopment, Addis Ababa, Ethiopia: Conflict Management Division, Peace and Security Department, Commission of the African Union.

Ahinur, 2018. 新疆 2018 年将多措并举保障就业困难群体就业. Xinhua News, 11 January.

Amnesty International, 2017. Amnesty International Report 2016/17, s.l.: Amnesty International.

Anata, A., 2006. Migration and Violent Conflicts in Some Southeast Asian Regions. Population Reveiw, 45(1), pp. 1-5.

Annan, J., Blattman, C., Mazurana, D. \& Carlson, K., 2011. Civil War, Reintegration, and Gender in Northern Uganda. The Journal of Conflict Resolution, 55(6), pp. 877-908.

Anon., 2009. The riots in Xinjiang: Is China fraying?. The Economists, 9 July.

Baines, E. K., 2003. Body Politics and the Rwandan Crisis. Third World Quarterly, 24(3), pp. $479-493$.

Baisley, E., 2014. Genocide and Construction of Hutu and Tutsi in Radio Propaganda. Race and Class, 55(3), pp. 38-59.

Baker, J. W., 2010. Flourishing borders, prosperous nationalities? A human security approach to identifying the underlying causes of ethnic conflict in china. Washington D.C.: ProQuest Dissertations \& Theses Global.

Barter, S. J. \& Côté, I., 2015. Strife of the soil? Unsettling transmigrant conflicts in Indonesia. Journal of Southeast Asian Studies, 46(1), pp. 60-85.

BBC Chinese, 2012. 新疆天價切糕引網友熱議民族關係 (Xinjiang Heavenly-Priced Nut Cake Sparks Discussion on Interethnic Relationships), s.l.: BBC News.

Becquelin, N., 2000. Xinjiang in the nineties. The China Journal, 44(44), pp. 65-90.

Becquelin, N., 2000. Xinjiang in the Nineties. The China Journal, Volume 44, pp. 75-98. 
Becquelin, N., 2004. Staged Development in Xinjiang. The China Quarterly, Issue 178, pp. 358-370.

Becquelin, N., 2004. Staged Development in Xinjiang. The China Quarterly, Volume 178, pp. 358-378.

Bedford, K., 2009. Developing Partnerships: Gender, Sexuality and the Reformed World Bank. Minneapolis: University of Minnesota Press.

Bergsten, C. F., Freeman, C., Lardy, N. R. \& Mithcell, D. J., 2008. China's Rise: Challenges and Opportunites, Washington, D.C: Peterson Institute for International Economics and Centre for Strategic and International Studies..

Berik, G., Dong , X. \& Summerfiled, G., 2007. China's Transition and Feminist Economics. Feminist Economics, 13(3-4), pp. 1-33.

Bittner, A. \& Goodyear-Grant, E., 2017. Digging Deeper into the Gender Gap: Gender Salience as a Moderating Factor in Political Attitudes. Canadian Journal of Political Science, 50(2), pp. 559-578.

Blomberg, S., Hess, G. \& Thacker, S., 2006. On the Conflict-Poverty Nexus. Economics and Politics, Volume 18, pp. 237-267.

Bloom, M., 2007. Female Suicide Bombers: A Global Trend.. Daedalus, Volume Winter 2007, pp. 97-102.

British Petroleum, 2017. Statistical Review of World Energy, London: BP P.L.C.

Brown, M. E., 1994. Cause and Implications of Ethnic Conflict. In: M. E. Brown, ed. Ethnic Conflicts and International Security. Princeton: Princess University Press, pp. 6-12.

Brown, M. E., 1996. The International Dimensions of Internal Conflict. Cambridge(Mass): MIT Press.

Bryant-Tarpeh, B., 2012. Challenges for Internally Displaced and Refugee Women in Gaining Access to Land for Food Security and Production in Post-Civil War Sierra Leone (20022011).. s.l.:Howard University.

Burt, R., 1982. Toward a Structural Theory of Action. New York: Academic Press.

Caprioli, M. \& Boyer, M., 2001. Gender, Violence, and International Crisis. Journal of Conflict Resolution, 45(1), pp. 503-518.

Caruso, R., 2012. Differentials in property Rights in a two-sector economy. Revue d'économie politique, Volume 122, pp. 257-278. 
CCTV News, 2013. "Xinjiang Maralbexi County 4-23 Serious Violence Terrorism Case Matyrs List Announced.". [Online] Available at: https://news.qq.com/a/20130429/000207.htm (N [Accessed 22 October 2017].

Cederman, L., Weidmann, ,. N. \& Gleditshch, K., 2011. Horizontal Inequalities and Ethnonationalist Civil War: A Global Comparison. American Political Science Review, 105(3), pp. 478-495.

Chandler , D., 2015. Rethinking the Conflict-Poverty Nexus: From Securitising Intervention to Resilience.. Stability: International Journal of Security and Development, 4(1).

Chen, C., 2009. 新疆的分裂与反分裂斗争 (Xinjiang's Separatist and Anti-Separatist Struggles). s.l.:Publishing House of Minority Nationalities.

Chen, Y.-W., 2012. 'Xinjiang 13' revisited. Asian Ethnicity, 13(1), pp. 111-113.

Chinese Communist Party 15th Central Committee, 1999. 中共中央关于国有企业改革和 发展若干重大问题的决定 (The CPC Central Committee's Decision on Reform and Development of State-owned Enterprises and Several Important Issues). s.1.:s.n.

Chinkin, C. \& Kaldor, M., 2013. Gender and New Wars. Journal of International Affairs, Volume Fall/Winter, pp. 136-151.

Clarke, M., 2008. China's "War on Terror" in Xinjiang: Human Security and the Causes of Violent Uighur Separatism. Terrorism and Political Violence, 20(2), pp. 271-301.

Clarke, M., 2015. China and the Uyghur. Middle East Policy: The "Palestinization" of Xinjiang?, 22(3), pp. 127-146.

Clarke, M. E., 2008. China's Integration of Xinjiang with Central Asia: Securing a "Silk Road" to Great Power Status?. China and Eurasia Forum Quarterl, 6(2), pp. 89-111.

Cliff, T. M. J., 2009. Neo Oasis: The Xinjiang Bingtuan in the Twentyfirst Century. Asian Studies Review, 33(1), pp. 83-106.

Clionadh, R., 2011. The Search for Safety: The Effects of Conflict, Poverty and Ecological Influences in the Developing World. Global Environmental Change, 21(1), pp. 8293.

Cohen, S. P., 1981. Sons of the Soil: Migration and Ethnic Conflict in India (Book Review). Journal of Asian Studies, 40(2), pp. 415-417.

Collier, P. \& Hoeffler, A., 1998. On economic causes of civil war.. Oxford Economic Papers, 50(4), pp. 563-573. 
Collier, P. \& Hoeffler, A., 2004. Greed and grievance in civil war.. Oxford Economic Papers, 56(4), pp. 563-595.

Congressional-Executive Commission on China, 2010. Annual Report, Washington: s.n.

Connor, W., 1994. Ethnonationalism: The Quest for Understanding. Princeton(N.J.):

Princeton University Press.

Cordell, K. \& Wolff, S., 2009. Ethnic Conflict. Cambridge: Polity Press.

Cote, I., 2015. The enemies within: Targeting Han and Hui migrants in Xinjiang. Asian Ethnicity, 16(2), pp. 135-151.

Côté, I., 2011. Political Mobilization of A Regional Minority: Han Chinese Settlers in Xinjiang. Ethnic and Racial Studies, 34(11), pp. 1855-1873.

Côté, I., 2014. Internal migration and the politics of place: A comparative analysis of China and Indonesia. Asian Ethnicity, 15(1), pp. 111-129.

Côté, I., 2015. Horizontal Inequalities and Sons of the Soil Conflict in China. Civil Wars, 17(3), pp. 357-378.

Côté, I. \& Huang, L. E., 2017. Of Men and Land: A Political Economy Approach to SoS Violence. Toronto(ON): Canadian Political Science Association.

Côté, I. \& Mitchell , M. I., 2017. Deciphering 'Sons of the Soil' Conflicts: A Critical Survey of the Literature. Ethnopolitics, 16(4), pp. 333-351.

Decoteau, C., 2011. Review of "Developing Partnerships: Gender, Sexuality and the Reformed World Bank," by Kate Bedford. Journal of World-Systems Research, 17(2), pp. 564-567.

Department of Human Resources and Social Security of Xinjiang Uygur Autonomous Region, 2010. 关于开展 2010 年“春风行动”的通知 (Notice on Conducting 2010 "Spring Breeze Action"). Urumqi: s.n.

Department of Human Resources and Social Security of Xinjiang Uygur Autonomous Region, 2015. 关于做好今冬明春农村劳动力转移就业培训的通知. Urumqi: s.n.

Department of Publicity of CPC XUAR Commitee, 2007. 新疆农村富余劳动力转移就业 (Xinjiang Rural Surplus Labour Migrate and Work). [Online]

[Accessed 10 December 2017].

Deshingkar, P., 2006. Internal Migration, Poverty and Development in Asia: Including the Excluded. IDS Bulletin, 37(3), pp. 88-100.

Dillon, M., 2003. Xinjiang: China's Muslim Far Northwest. 1st ed. London: Routledge. 
Ding, X., 2017. 关于解放南疆少数民族女性生产力与实现男女平等问题的思考

(Thoughts on Emancipating Southern Xinjiang Ethnic Minority Women's Productive Ability and Realizing Gender Equality_. Journal of Kashgar University, Issue 2.

Dong, S., Chen, F. \& Li, Y., 2015. “短平快”项目为梦想助力. Xinjiang Daily, 11 March .

Do, Q.-T. \& Iyer, L., 2009. Geography, Poverty and Conflict in Nepal. Harvard Business School Working Paper 07-065, February.

Dorian, J. P., Widgortz, B. \& Gladney, D., 1997. Central Asia and Xinjiang, China: Emerging Energy, Economic and Ethnic Relations. Central Asian Survey, 16(4), pp. $461-486$.

Dorian, J. P., Wigdortz, B. H. \& Gladney, D. C., 1997. China and Central Asia's Volatile Mix: Energy, Trade, and Ethnic Relations. Asia Pacific Issues: Analysis from the East-West Center, May, Issue 31, pp. 1-8.

Enloe, C., 2000. Maneuvers: The International Politics of Militarizing Women's Lives. Berkley: University of California Press.

Enloe, C., 2007. Globalization and Militarism: Feminists Make the Link. Toronto: Rowman \& Littlefield Publishers Inc..

Esman, M. J., 1994. Ethnic Politics. Ithaca(NY): Cornell University Press.

Executive Office of the People's Government of Xinjiang Uyghur Autonomous Region, n.d. 新疆印象 (Impression of Xinjiang) . [Online] Available at: http://www.xinjiang.gov.cn/ljxj/index.html [Accessed 22 November 2017].

Fearon, J. D. \& Laitin, D. D., 2003. Ethnicity, Insurgency, and Civil War. American Political Science Review, February, 97(1), pp. 75-90.

Fearon, J. D. \& Laitin, D. D., 2011. Sons of the Soil, Migrants, and Civil War. World Development, 39(2), pp. 199-211.

Food and Agriculture Organization of the United Nations, 2018. Gender and Land Rights Database. [Online]

Available at: http://www.fao.org/gender-landrights-database/en/

Gao, M. \& Zhu, M., 2013. 新疆对外劳务输出的优劣势及效应分析 (Analysis on Xinjiang Labour Export, Its Advantages, Disadvantages, and Impacts). Economic Research Guide, Issue 17, pp. 122-123.

General Office of the State Council of the People's Republic of China, 2015. 国务院办公 厅关于支持新疆纺织服装产业发展促进就业的指导意见. s.l.:s.n. 
Geng, D., 2018. 新疆农民“变”工人：带“技”就业促脱贫. China News Agency, 12 March.

Geschiere, P. \& Jackson, S., 2006. Autochthony and the Crisis of Citizenship:

Democratization, Decentralization, and the Politics of Belonging. African Studies Review, September, 49(2), pp. 1-7.

Gladney, D. C., 2004. Dislocating China: Muslims, Minorities and Other Subaltern Subjects. Chicago: University of Chicago Press.

Gladney, D. C., 2013. Responses to Chinese Rule in Xinjiang: Patterns of Cooperation and Opposition. The Mongolian Journal of International Affairs, Volume 10, pp. 102119.

Goldstein, J., 2001. War and Gender: How Gender Shapes the War System and Vice Versa. Cambridge: Cambridge University Press.

Golovnina, M., 2007. Kazakhstan, China agree to press ahead with pipeline. [Online] Available at: https://uk.reuters.com/article/kazakhstan-chinapipeline/kazakhstan-china-agree-to-press-ahead-with-pipelineidUKL0888292120071108 [Accessed 8 January 2018].

Hamid, S., 2010. Rural to Urban Migration in Pakistan: The Gender Perspective. Karachi, Pakistan Institute of Development Economics.

Han, L., 2017. 新疆短平快项目让 16 万人就业 (Xinjiang Rapid Strike Projects Employing 160000 People). People's Daily, 6 January.

Hannibal, T., 2008. Genocide in Sudan: the role of oil exploration and the entitlement of the victims to reparations.. Arizona Journal of International and Comparative Law, 25(1), p. 75.

Han, Y., 2010. 新疆维吾尔自治区历任党委书记名单 (List of Former Secretaries of Party Committee of XUAR). People, 26 April.

Hao, S., 2015. 中国民族识别的学术争论背景 (Background of the Academic Debate on China's Minzu Classification). 18 May.

Hao, Y. \& Liu, W., 2012. Xinjiang: increasing pain in the heart of China's borderland. Journal of Contemporary China, 21(74), pp. 205-225.

Henshaw, A., 2017. Why Women Rebel: Understanding Female Participation in Intrastate Conflict. London: Routledge.

Hess, S. E., 2010. Islam, local elites, and China's missteps in integrating the Uyghur nation. USAK Yearbook Of International Politics and Law. . 
Horowitz, D. L., 1985. Ethnic Groups in Conflict. Berkeley(CA): University of California Press.

Hossein, C. S., 2016. Politicized microfinance : money, power, and violence in the Black Americas. Toronto: University of Toronto Press.

Human Rights Watch, 2016 . China: Passports Arbitrarily Recalled in Xinjiang. [Online] Available at: https://www.hrw.org/news/2016/11/21/china-passportsarbitrarily-recalled-xinjiang [Accessed 27 November 2017].

International Energy Agency, 2015. World Energy Outlook 2015 Executive Summary, Paris: International Energy Agency/Organisation for Economic Co-operation and Development.

Jackson, S., 2003. Fortunes of War: The Coltan Trade in the Kivus. London, Overseas Development Institute.

Jackson, S., 2006. Sons of Which Soil? The Language and Politics of Atohthony in Eastern D.R. Congo. African Studies Review, 49(2), pp. 95-123.

Jacobs, A., 2009. At a Factory, the Spark for China's Violence. New York Times, 15 July .

Jaleel, R., 2013. Weapons of Sex, Weapons of War. Cultural Studies, 27(1), pp. 115-135.

Jiang, J. \& Fang, Y., 2014. CHINA Xinjiang county awards 50,000 yuan for tip-offs. Global Times, 24 April .

Joniak-Lüthi, A., 2016. Blurring boundaries and negotiating subjectivities - the Uyghurized Han of southern Xinjiang, China. Ethnic and Racial Studies, 39(12), pp. 2187-2201.

Kaufman, S. J., 2001. Modern Hatreds: The Symbolic Politics of Ethnic War. Ithaca(NY): Cornell University Press.

Kelkitlì, F. A., 2014. The Meeting of the Crescent and the Dragon: PostCold War SinoTurkish Rivalry and Cooperation in Central Asia and the Middle East. Orta Asya ve Kafkasya Araştırmaları, Volume 17, pp. 149-178.

Kirby, P., 2013. How is rape a weapon of war? Feminist International Relations, modes of critical explanation and the study of wartime sexual violence. European Journal of International Relations, 79(4), pp. 797-821.

Klein, R. et al., 2010. Democracy and Conflict in Southern Thailand: A Survey of the Thai Electorate in Yala, Narathiwas, and Pattani, s.l.: The Asia Foundation. 
Kolsto, P. \& Blakkisrud, H., 2013. Yielding To The Sons of The Soil: Abkhazian Democracy and The Marginalization of The Armenian Vote.. Ethnic and Racial Studies, 36(12), pp. 2075-2095.

Kurtz, R. \& Bartles , C., 2007. Chechen Suicide Bombers. Journal of Slavic Military Studies, Volume 20, pp. 529-547.

Lahai, J., 2010. Gendered Battlefields: A Contextual and Comparative Analysis of Women' Participation in Armed conflicts in Africa.. Peace and Conflict Review, 4(2), pp. 1-15.

Lake, D. \& Rothchild, D., 1998. Spreading Fear: The Genesis of Transnational Ethnic Conflict. In: The International Spread of Ethnic Conflict: Fear, Diffusion, and Escalation. Princeton(NJ): Princeton University Press.

Liang, Z. \& Chen, Y. P., 2004. Migration and Gender in China: An Origin-Destination Linked Approach. Economic Development and Cultural Change, 52(2), pp. 423-443.

Li, G. \& Pan, M., 2015. 新疆维吾尔族农民从“固守田园”到“外出务工嬗变的理性分析 (The Transmutation of Xinjiang Uighur Farmers Who Are from "Stick to the Pastoral" to "Egress Laboring"). Population and Development, 2015(5), pp. 89-96.

Li, G. \& Pan, M., 2015. The Transmutation of Xinjiang Uighur Farmers Who Are from " Stick to the Pastoral" to "Egress Laboring" . Population and Development, Issue 5, pp. 89-96.

Li, J. \& Chang, Q., 2015. 新疆各主要民族人口现状及变化特征 (The Current Status and Dynamic Characteristics of Xinjiang's Population of Major Ethnic Groups). 西北 民族研究 N. W. Journal of Ethnology, Volume 86.

Lu, K. \& Breuning, M., 2014. Gender and Generosity: Does Women's Representation affect development cooperation?. Politics, Groups, and Identities, 2(3), pp. 313-330.

Ma , R., 2007. Rural Migrant Workers from South Xinjiang Uygur to Coastal Cities -- A Case Study on Shufu County, Xinjiang Uyghur Autonomous Region. Chinese Journal of Population Science, October, Issue 5, pp. 24-35.

Meger, S., 2015. Toward a Feminist Political Economy of Wartime Sexual Violence. International Feminist Journal of Politics, 17(3), pp. 416-434.

Miguel, E., Satyanath, S. \& Sergenti, E., 2004. Economic shocks and civil conflict: an instrumental variables approach. Journal of Political Economy, 112(4), pp. 725-753.

Millward , J. A., 2009. Introduction: Does the 2009 Urumchi violence mark a turning point?. Central Asian Survey, 28(4), pp. 347-360. 
Ministry of Foreign Affairs of the People's Republic of China, 2016. 共建“一带一路”，再 创丝路辉煌 - - 外交部长王毅在第十七届“蓝厅论坛”上的致辞 (Building the Belt and Road Together, Reinvigorating the Glamour of Silk Road--Foregin Minister Wang $Y i$ 's Speech at the Lanting Forum). [Online] Available at: http://www.fmprc.gov.cn/web/wjbz_673089/zyjh_673099/t1386726.shtml [Accessed 22 November 2017].

Ministry of Human Resources and Social Security of the People's Republic of China, 2008. 人力资源和社会保障部关于进一步促进新疆劳动和社会保障事业发展的意见 (Ministry of Human Resources and Social Security's Opinion on Further Promoting the Development of Xinjiang's Labour and Social Protection). Beijing: s.n.

Ministry of Human Resources and Social Security of the People's Republic of China, 2014. 新疆大力开展农民工职业技能培训. [Online]

Available at:

http://www.mohrss.gov.cn/nmggzs/NMGGZSgongzuodongtai/201412/t2014 1229_147495.html

[Accessed 10 November 2017].

Ministry of Human Resources and Social Security of the People's Republic of China, 2015. 国务院办公厅印发《关于支持新疆纺织服装产业发展促进就业的指导意见》。 s.1.:s.n.

Ministry of Human Resources and Social Security of the People's Republic of China, 2017. 新疆出了家门进厂门脱贫致富学技能. s.l.:s.n.

Mitchell, M. I., 2012. Migration, Citizenship and Autochtony: Strategies and Challenges for State-Building in Côte D'Ivoire. Journal of Contemporary African Studies, 30(2), pp. 267-287.

Mukherjee, S., 2014. Articles Why Are the Longest Insurgencies Low Violence? Politician Motivations, Sons of the Soil, and Civil War Duration. Civil Wars, 16(2), pp. 172-207.

Murshed, S. M., 2005. Globalisation, Marginalisation and Conflict. In: M. Spoor, ed. Globalisation, Poverty and Conflict: A Critical "Development" Reader. Dordrecht: Spinger, pp. 67-80.

National Bureau of Statistics of People's Republic of China, 2012. China Statistics Yearbook 2012, Beijing: China Statistics Press.

National Bureau of Statistics of People's Republic of China, 2016. China Statistic Year Book, Beijing: China Statistics Press. 
National Bureau of Statistics of the People's Republic of China, 2017. 2017 年三季度我国 GDP 初步核算结果 (Results of Preliminary Audit of GDP of the 3rd Quarter, 2017), Beijing: National Bureau of Statistics of the People's Republic of China.

National Bureau of Statistics of the People's Republic of China, 2017. Xinjiang Production and Construction Corps Statistical Yearbook .... Beijing: China Statistics Press.

National Development and Reform Commission of People's Republic of China, 2014. 新 疆实施“短平快” 产业项目 推动南疆贫困地区就业 (Xinjiang Conducts Rapid Spike Industrial Projects, Promoting Employment of Impoverished Region in Southern Xinjing). [Online] Available at: http://www.ndrc.gov.cn/fzgggz/jyysr/jqyw/201402/t20140227_656829.html [Accessed 20 November 2017].

Nyíri, P., 2005. The "New Migrant": State and Market Constructions of Modernity and Patriotism. In: J. Breidenbach \& P. Nyíri, eds. China Inside Out: Contemporary Chinese Nationalism and Transnationalism. Budapest: Central European University Press.

Organisation of Economic Cooperation and Development , 2011. Supporting Statebuilding in Situations of Conflict and Fragility: Policy Guidance, Paris: OECD Publishing.

Oriental Review, 2013. Xinjiang in Focus of US Foreign Policy. Oriental Reviw: Open Dialogue Research Journal, 8 March.

Pankhurst, D., 2008. The Gendered Impact of Peace. In: M. Pugh, N. Cooper \& M. Turner, eds. Whose Peace? Critical Perspectives on the Political Economy of Peacebuilding. Houndmills: Palgrave MacMillon, pp. 30-46.

Pateman, C., 1988. The Sexual Contract. s.l.:Princeton University Press.

Paul , C. \& Anke, H., 2006. Greed and Grievance. Oxford Economics Papers, Volume 56, pp. 563-593.

Peace Research Institute Oslo, 2016. The Battle Deaths Dataset Version 3.0. [Online] Available at: https://www.prio.org/Data/Armed-Conflict/Battle-Deaths/TheBattle-Deaths-Dataset-version-30/

Peluso, N. L., 2008. A political ecology of violence and territory in West Kalimantan. Asia Pacific View Point, April, 49(1), pp. 48-67.

People, 2014. 中国石油在中亚之管道篇：油气管道奠格局 (Petrochina in Central Asia: Pipelines and Structures). [Online] 
Available at: http://energy.people.com.cn/n/2014/1115/c71661-26031144.html [Accessed 8 January 2018].

People's Daily International, 2009. 韶关旭日公司员工斗殴案一审公判 (First Public Trial of Shaoguan Xuri Company Employees Brawls). 12 October.

People's Daily, 2017. 新疆维吾尔自治区去极端化条例 (XUAR Regulation of Deextremitisation). People's Daily, 30 March .

People's Republic of China State Council , 2010. Regulation of National Census, State Council Ordinance No. 576. Beijing: s.n.

Peterson, S., 2006. How (the meaning of) Gender Matters in Political Economy.. New Political Economy., 10(4), pp. 499-521.

Peterson, V. S., 2003. critical rewriting of global political economy: integrating reproductive, productive, and virtual economies. London: Routledge.

Peterson, V. S., 2010. Gender matters in global politics: a feminist introduction to international relations. New York: Routeledge.

Pettis , M., 2013. The Great Rebalancing: Trade, Conflict, and the Perilous Road Ahead for the World Economy. Princeton(NJ): Princeton University Press.

Phoenix News, 2013. "Xinjiang Maralbexi Violence Terrorism Case All 25 Individuals Captured, Premediated A Big Incident This Summer.". [Online]

Available at:

http://news.ifeng.com/mainland/detail_2013_04/29/24807727_0.shtml [Accessed 22 October 2017].

Potter, P. B., 2007. In: D. Lary, ed. The Chinese state at the borders. Vancouver: UBC Press, pp. 240-270.

Qiao, L., 2017. Kazakhstan Residents With Family in China Protest Document Confiscation Drive. [Online]

Available at: http://www.rfa.org/english/news/china/kazakh-passport06132017125051.html?searchterm:utf8:ustring=china + passport+uyghur [Accessed 27 November 2017].

Radford, J., 2002. Gender and Choice in Education and Occupation. London: Routledge.

Ramachandran, V., 2017. Redefining China's Xinjiang policy: Rhetoric or reality?. International Area Studies Review, 20(3), pp. 273-290.

Rankin, K., 2001. Governing Development: Neoliberalism, Microcredit, and Rational Economic Woman. Economy and Society, 30(1), pp. 18-37. 
Ren, Q., Ma, X. \& Ma, H., 1998. Analysis of Xinjiang's Floating Population. Population Research, 22(6).

Riley, M., 2008. Feminist Political Economic Framework, Washington, DC: Centre for Concern.

Ritzer, G., 2010. Globalization. s.l.:s.n.

Roberson, C. \& Klein, M., 1983. Women and Slavery in Africa. s.l.:University of Wisconsin Press.

Roche, C., 2012. Gender in Narrative Memory: The Example of Civil War Narratives in Tajikistan. Ab Imperio, 2012(3), pp. 279-307.

Rui, D., 2014. 习近平的反恐决心与乌鲁木齐的“暴恐”事件 (Xi Jinping's Determination on Counter-terrorism and the Violent and Terrorist Incident in Urumqi). Radia Free International, 1 May.

Ryono, A. \& Galway, M., 2015. China: reflections on the multiple dimensions of the 2009 Urumqi uprising. Asian Ethnicity, 16(2), pp. 235-255.

Sambanis, N., 2004. What Is Civil War? Conceptual and Empirical Complexities of an Operational Definition. Journal of Conflict Resolution, December, 48(6), pp. 814858.

Shanghai Office of Local Chronicles, n.d. Shanghai Chronicles of Religion. [Online] Available at:

http://www.shtong.gov.cn/node2/node2245/node75195/node75202/node7527 1/node75277/userobject1ai91696.html

[Accessed 19 November 2017].

Singer , J. D. \& Small, M., 1982. Resort to arms: International and civil war, 1816-1980. Beverly Hills(CA): Sage.

Singer, D., 2006. The Level-of-Analysis Problem in International Relations. Uluslararasilliskiler3, Issue 11, pp. 3-24.

Sjoberg, L., 2013. Gendering Global Conflict Toward a Feminist Theory of War. New York: Columbia University Press.

Smith, A. D., 1991. National Identity. London: Penguin.

Standardization Administration of the People's Republic of China, 2017. Industrial classification for National Economic Activities, Beijing: Standardization Administration of the People's Republic of China. 
Statistics Bureau of Xinjiang Uyghur Autonomous Region, 2017. Xinjiang Statistics Yearbook, Urumqi: s.n.

Stewart, F., 2008. Horizontal Inequalities and Conflict: Understanding Group Violence in Multiethnic Societies. Hampshire: Palgrave Macmillan.

Strange, S., 1998. States and Market. 2nd ed. s.l.:Bloomsbury Academic.

Sudarshan, R. M. \& Mukhopadhyay, S., 2003. Gender and Adjustment Policies:

Evidence from Pakistan. In: Tracking gender equity under economic reforms: continuity and change in South Asia. Ottawa: International Development Research Centre, pp. 153-195.

Sunga, L. S., 2014. Does Climate Change Worsen Resource Scarcity and Cause Violent Ethnic Conflict. International Journal of Minority and Group Rights, Volume 21, pp. $1-24$.

Tambiah, S. J., 1986. Sri Lanka-- Ethnic Fratricide and the Dismantling of Democracy. Chicago: The University of Chicago Press.

Tarrow, S., 2005. The New Transnational Activism. Cambridge: Cambridge University Press.

Thapar, S., 1993. "Women as Symbols: A Study of the Indian Nationalist Movement. Feminist Review, Volume 44, pp. 81-96.

The Economist, 2009. The Riots in Xinjiang: Is China Fraying?. 9 July.

The General Administration of Quality Supervision, Inspection and Quarantine of the People's Republic of China; Standardization Administration of China, 2017. Industrial Classification for National Economic Activities. Beijing : The General Administration of Quality Supervision, Inspection and Quarantine of the People's Republic of China; Standardization Administration of China.

The Initium News, 2017. 新疆启动今年最大规模维稳部署, 但暴恐事件仍不断上演 (Xinjiang Initiates the Largest Scale Stability Maintenance Deployment, But Terrorist Violence Still Recurring). The Initium, 22 Februrary.

The Ministry of Science and Techonology of the People's Republic of China, 2002. 新疆: 西部大开发战略实施 (Xinjiang: The Great Western Region Development Initiative Implemented). [Online] Available at: http://www.most.gov.cn/ztzl/xbkfkjzx/200206/t20020609_7805.htm [Accessed 6 April 2018]. 
The Shanghai Cooperation Organisation, 2017. About SCO. [Online] Available at: $\underline{\text { http://eng.sectsco.org/about_sco/ }}$ [Accessed 28 November 2017].

The State Council Information Office of the People's Republic of China, 2014. 《新疆生 产建设兵团的历史与发展》白皮书 (White Paper on History and Development of Xinjiang Production and Construction Corps), Beijing: The State Council Information Office of the People's Republic of China.

The State Council Information Office of the People's Republic of China, 2016. 新疆 : 精 准扶贫是 2016 年促就业计划重点. [Online] Available at: http://www.scio.gov.cn/dfbd/dfbd/Document/1473597/1473597.htm

The United Nations, 2018. No Poverty: Why It Matters, s.l.: The United Nations.

Tilly, C. \& Tarrow, S., 2015. Contentious Politics. 2nd ed. Oxford: Oxford University Press.

Tsuneda, M., 2009. Navigating life on the border: Gender, migration, and identity in malay muslim communities in southern thailand. Madison(Wisconsin): ProQuest Dissertations \& Theses Global.

Tsuo, K., 2009. How the West Was Lost: China's Xinjiang Policy. Harvard International Review, Fall.p. 10.

Turshen, M., 2016. Gender and the Political Economy of Conflict in Africa: The Persistence of Violence. Basingstoke: Routledge.

U.S. Energy Information Administration, 2017. World Oil Transit Chokepoints, Washington: U.S. Department of Energy.

United Nations Development Programme, 2009. Human Development Report: Overcoming barriers: Human Mobility and Development, s.l.: Palgrave Macmillam.

United Nations, 2008. International Standard Industrial Classification of All Economic Activities Revision 4, New York: United Nations.

Volodzko, D., 2015. Souls of Uighur Folk. The Nanfang.

Wallerstein, I. M., 1974. The modern world-system. New York: Academic Press.

Wang, J., 2009. 乌鲁木齐“七·五”事件不影响新疆劳务输出政策 (Urumqi 7/5 Incident Not Impacting Xinjiang Labour Export Policy). People's, 10 July.

Wang, J., 2015. Terrorism In and From Xinjiang. In: G. R. Barmé, L. Jaivin \& J. Goldkorn, eds. Shared Destiny. Acton: Australian National University Press, pp. 308-315. 
Waring, M., 1988. If Women Counted: A New Feminist Economics. San Francisco: Harper \& Row.

Wei, B.-k., 2008. 中國與中亞的能源關係：合作與挑戰 (China - Central Asia Energy Relations: Cooperation and Challenges). 國際關係學報 (The Journal of International Relations), January, Volume 25, pp. 45-75.

Weidmann, N. B., 2009. Geography as Motivation and Opportunity: Group Concentration and Ethnic Conflict. Journal of Conflict Resolution, 53(4), pp. 526543.

Weiner , M., 1978. Sons of the Soil Migration and Ethnic Conflict in India. Princeton(N.J.): Princeton University Press.

Welsh, D., 1994. Domestic Politics and Ethnic Conflcit. In: M. E. Brown, ed. Ethnic Conflicts and International Security. Princeton: Princeton University Press.

Wiemer, C., 2004. Xinjiang: China's Muslim Borderland. In: F. S. Starr, ed. Armonk(NY): M.E. Sharpe, pp. 163-189.

Wolff, S., 2006. Ethnic Conflict: A Global Perspective. Oxford: Oxford University Press.

Wong, E., 2016. Police Confiscate Passports in Parts of Xinjiang, in Western China. New York Times, 2 December .

Xinhua News Agency, 2016. 陈全国当选中共新疆维吾尔自治区党委书记 (Chen Quanguo Elected as Secretary of the XUAR Party Committee). [Online] Available at: $\underline{\mathrm{http}}$ ://www.thepaper.cn/newsDetail_forward_1553894 [Accessed 27 November 2017].

Xinjiang Production and Construction Corps, 2018. 走进兵团 (Approaching the XPCC). [Online] Available at: http://www.xjbt.gov.cn/bt/ [Accessed 30 March 2018].

Xinjiang Uyghur Autonomous Region People's Government, 2018. Government Work Report, Urumqi: s.n.

Yang, Z., 2017. 專訪: 當我們對「新疆人」的認識只有標籤，那還談什麼國際觀？ (Interview: How Can We Talk about Global Perspectives When Our Understanding of People of Xinjiang Is Reduced to Labels? ) [Interview] (13 May 2017).

Yao, T., Yuan, L. \& Dong, S., 2015. 新疆维吾尔自治区党委南疆工作会议举行 张春贤发表 重要讲话(Working Meetings Held for Xinjiang Uyghur Autonomous Region Party Committee, Zhang Chunxian Delivered Significant Speech). [Online] 
Available at: http://cpc.people.com.cn/n/2015/1104/c64094-27776954.html [Accessed 27 November 2017].

Yin, W., 2015. THE NATURAL RESOURCE CURSE IN XINJIANG. CEU Political Science Journal, 01(02), pp. 112-140.

Young, C., 1976. The Politics of Cultural Pluralism. Madison(Wisconsin): University of Wisconsin Press.

Østby, G., 2008. Polarization, Horizontal Inequalities and Violent Civil Conflict. Journal of Peace Research, 45(2), pp. 143-162.

Zang, X., 2008. Gender and Ethnic Variation in Arranged Marriages in a Chinese City. Journal of Family Issues, 29(5), pp. 615-638.

Zang, X., 2010. Affirmative Action, Economic Reforms, and Han-Uyghur Variation in Job Attainment in the State Sector in Urumchi. The China Quarterly, June, Volume 202, pp. 344-361.

Zang, X., 2011. Uyghur-Han Earnings Differentials in Urumchi. The China Journal, Issue 65, pp. 141-155.

Zang, X., 2012. Gender Roles and Ethnic Income Inequality in Urumchi. Ethnic and Racial Studies, 35(2), pp. 238-258.

Zeng, P., 2010. 西部大开发决策回顾 (A Review of the Great Western Region Development). Beijing: Chinese Communist Party History Publishing House.

Zhang, E. N., 2015. “一带一路是为了让中国国企向外输出过剩產能 (One Belt One Road is the Outlet for Chinese SOEs' Excess Capacity). China Times, 13 November.

Zhang, L., Zhang, L. \& Hu, Z., 2015. 克州“短平快”和服装纺织项目促农牧民思想观念发 生巨变. China National Radio, 1 January.

Zhang, S. \& McGhee, D., 2014. Social Policies and Ethnic Conflict in China: Lesson from Xinjiang. s.l.:Palgrave Macmillan.

Zhang, Y., 2009. 乌鲁木齐“7・5”事件主要特点及其引发的意识形态几点思考 (The Characteristics of Urumqi 7/5 Incident and the Thoughts on Ideologies Regarding the Incident). [Online]

Available at: http://www.xjass.com/zxdt/content/200910/22/content_113270.htm [Accessed 19 November 2017].

Zhang, Y., 2012. 关于新疆经济结构战略性调整的思考(Thoughts on Strategic Adjustment of Xinjiang Economic Structure). s.l., China Finance Association. 
Zhao, Y., 2001. Pivot or Periphery? Xinjiang's Regional Development. Asian Ethnicity, 2(2), pp. 200-201.

Zhao, Y., 2008. Communication in China: Political Economy, Power, and Conflict. Pymouth: Rowman \& Littlefield Publishers.

Zhou, X., 2003. 西部大开发与飞跃式发展 (The Great Western Region Development and Leap Development ). Journal South-Central University for Nationalities, 23(3).

Zhu, Y. \& Blachford, D., 2016. ‘Old Bottle, New Wine'? Xinjiang Bingtuan and China's ethnic frontier governance. Contemporary China, 25(97), pp. 25-40. 